Historic, archived document

Do not assume content reflects current scientific knowledge, policies, or practices. 
LIBIRAIRY R E C E T T D

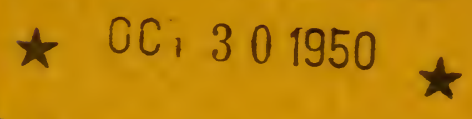

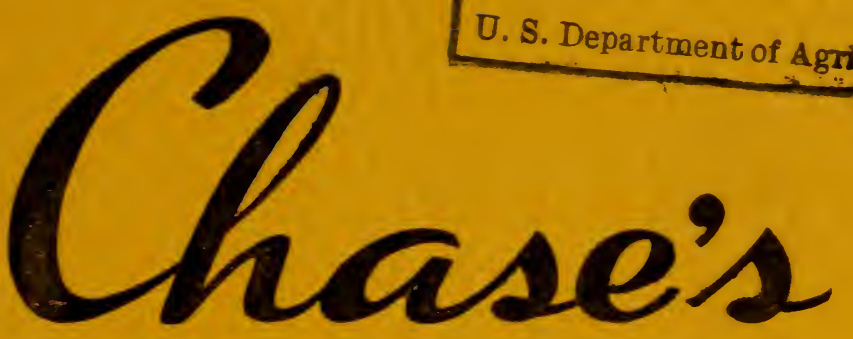

FALL - SPRING

$1950-1951$

TRADE LIST

for IN DEX - TELEPHONES Turn this Cover

\section{CHASE NURSERY CO.}

Chase, Alabama 


\section{N D E X}

Pages

Deciduous Shrubs and Trees ....... 5-26 Conifers $\ldots \ldots \ldots \ldots \ldots \ldots \ldots$ 26-28 Broadleaved Evergreens . . . . . . . . 29-32 Vines $\ldots \ldots \ldots \ldots \ldots \ldots \ldots \ldots \ldots . \ldots \ldots$ 32-34

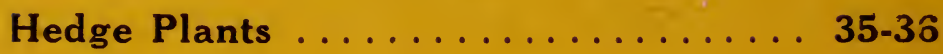
Roses .................. 36-37 Lining-Out Stock ............. 38-44 Nurserymen's Supplies . . . . . . . . . 45-72 Weight Schedule ........ Inside Back Cover

\section{TELEPHONES}

Service is Through Huntsville Exchange DAY CALLS

Office $\ldots \ldots \ldots \ldots \ldots \ldots$ Huntsville 162

\section{NIGHT CALLS}

H. B. Chase ......... Huntsville 126

H. H. Chase ......... Huntsville 2131 .

E. C. Rolfe ........... Huntsville 836-J 


\section{WHOLESALE PRICE LIST}

FALL 1950 - SPRING 1951

\section{CHASE}

\section{NURSERY COMPANY}

(INCORPORATED)

CHASE, ALABAMA

OCTOBER 9, 1950

President HENRY B. CHASE

Vice-President

CHARLES O. ROLFE

Secretary-Treasurer

HENRY H. CHASE

Superintendent

C. ROLFE

Chase, Alabama, is served by

WESTERN UNION TELEGRAPH COMPANY

N. C. \& ST. L. RAILWAY

SOUTHERN RAILWAY

RAILWAY EXPRESS AGENCY

MONEY ORDER POSTOFFICE

SPECIAL NOTICE

This list is intended for the TRADE ONLY. If it reaches people NOT entitled to Trade Prices, we will thank any Nurseryman or Florist to advise us, so that our mailing list may be corrected. We do not employ agents. We do not pack dealers' orders on our grounds. We do not authorize dealers to use our name. 
ALL PRICES ARE SUBJECT TO MARKET CHANGES

\section{TERMS AND CONDITIONS}

\section{TELEGRAPHIC INQUIRIES}

If you fail to receive a telegraphic reply to a telegraphic inquiry, it means that we CANNOT supply goods wanted. Our rule, in such cases; is to immediately acknowledge your wire by mail.

\section{SHIPMENTS}

PLEASE state how you want your shipments made, whether by freight or express; also route. Where no instructions are given, we: will ship as we think best serves your interest without assuming responsibility.

\section{TRANSPORTATION RISKS}

While we use every means at our command to secure prompt delivery, WE ARE NOT LIABLE FOR DELAYS IN TRANSIT; OUR RESPONSIBILITY ENDS UPON DELIVERY IN GOOD ORDER TO CARRIER. Remedy for loss must lie between the buyer and the carrier, but we will always render all the aid we can.

\section{TERMS-NURSERY STOCK}

1. Cash with order AND ALWAYS ADD 5\% for PACKING CHARGES. No more free packing.

2. To customers with known or approved credit rating. Net 30 days, $2 \% 10$ days.

3. C.O.D. Orders must be accompanied by at least $25 \%$.

4. All Boxes and Bales Are Extra At Cost.

TERMS - SUPPLIES (Always Net)

1. Cash with Order or C.O.D.

2. Net Cash 10 Days to known or approved credit rating.

3. No Cash Discount On Supplies - and no packing charges.

\section{PRICES}

This List is intended for the TRADE and should be found only in the hards of people who buy our products for resale at a profit.

We price "Per 10," "Per 100," and "Per 1000." To obtain the lowest published price on Naked Root deciduous stock your order must consist of at least fifty plants and not less than ten of a variety or grade.

Orcers for less than ten of a variety or grade will be invoiced at an ADVANCE of 50\% OVER THE TEN P.ATE, REGARDLESS OF THE SIZE OF THE ORDER, except Conifers and Broadleaved Evergreens where 5 plants at the 10 rate and 25 plants at the 100 rate are available.

Prices do not include packing charges. 


\section{GRADES}

We grade liberally. All shrubs of specified sizes are well furnished and well rooted. Culls are as rigidly excluded from the lightest grades listed as from the heaviest stock. Our rule is, "WHEN IN DOUBT, PUT IT IN THE LOWER GRADE." Detailed information as to method of grading Hedge Plants and Roses is given under such heads.

\section{CLAIMS}

All claims must be made immediately after receipt of stock.

\section{LIABILITY and NON-WARRANTY}

All quotations are for immediate acceptance and subject to stock being sold. All bookings are without liability to us should injury befall stock from frost, hail, fire, or other causes beyond our control, and subject to the standard form Non-Warranty Clause which reads: "We give no warranty, express or implied, as to description, productiveness, or any other matter, of any nursery stock, seed or bulbs we sell."

\section{COMBINATION CARLOAD SHIPMENTS}

When possible we combine shipments into carloads for distribution at Chicago, Cincinnati, Rochester, and St. Louis, often to other points, giving you benefit of $\mathrm{c} 1$ freight rate (plus the handling charge billed us by transfer companies) and quick through refrigerator car service.

\section{PACKING CHARGES}

Boxes and Bales will be charged at cost of labor and materials. This item will average around $5 \%$ of invoice. No charge for packing Car or Truck loads.

\section{REFERENCES}

As to our standing and responsibility we refer to any bank or business house in Huntsville, Alabama, the Commercial Agencies, and the leading nurserymen of the United States.

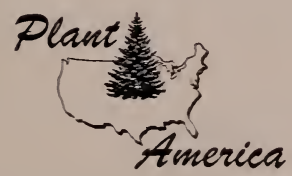




\section{THIS YEAR'S SPECIALS}

ALMOND, Flowering

(Both Pink and White) .......... 18

\section{DOGWOOD}

(Plena, Rubra, and White) . . . . . 8-9

HYDRANGEA QUERCIFOLIA

(Beautiful Oakleaf Hydrangea) ..... 12

JUNIPER GLAUCA HETZI LINERS

("Successor to Pfitzer") . . . . . . . . 41

\section{KOLKWITZIA AMABILIS}

(Very nice Beautybush) .......... 13

\section{MAGNOLIA SOULANGEANA}

(Three year heavily branched, well set with bloom buds.) . ....... 16

\section{RHUS COTINUS}

(Genuine Smoke Tree) ........... 20

\section{VIBURNUM OPULUS STERILE}

(Common Snowball) ............ 25

\section{WEEPING CHERRIES}

(Both Single and Double) ......... 19

\section{WEIGELA VANICEKI}

(The best of the Red Weigelas) ..... 26 


\section{DECIDUOUS SHRUBS AND TREES}

In listing plant material we follow Standardized Plant Names as far as practical.

We price Per Ten and Per Hundred. To obtain the lowest published price on naked root deciduous stock your order must cover at least fifty plants and not less than ten of a variety or grade. Orders for less than ten of a variety or grade will be invoiced at an advance of $50 \%$ over the Ten Rate regardless of the size of your order.

NOTE: The figure shown following the description of each variety indicates approximate height at maturity.

ABELIA-See Broadleaved Evergreens

\section{ALBIZZIA julibrissin, Silktree Albizzia} (Mimosa)

Very fast growing tree of spreading habit. Fragrant pink tinted feathery flowers are borne in great profusion during the Summer. The large grades have been staked and should develop into nice trees. 30 feet.

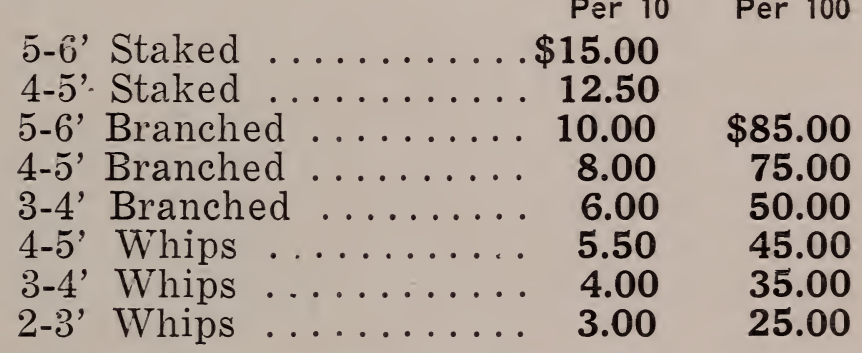

ALMOND, Flowering--See prunus glandulosa

ALTHEA-See Hibiscus syriacus

AMYGDALUS persica (Prunus persica), Flowering Peach

Large shrub or small tree completely covered in early Spring by mass of colorful bright blooms. One of the most attractive ornamentals. 12 feet.

PINK RED WHITE

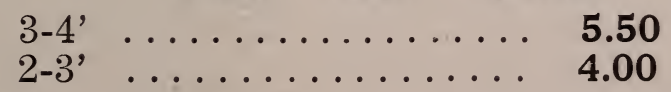

BEAUTYBUSH-See Kolkwitzia amabilis

\section{BERBERIS thunbergi, Green Barberry}

One of the best mass shrubs. Hardy and tough. Brilliant Fall foliage is followed by persistent scarlet berries. 5 feet.

$\begin{array}{llll}24-30, " & \ldots \ldots \ldots \ldots \ldots \ldots & 3.50 & 32.50 \\ 18-24, " & \ldots \ldots \ldots \ldots \ldots \ldots & 3.00 & 25.00 \\ 15-18, " & \ldots \ldots \ldots \ldots \ldots \ldots & 2.00 & 17.50 \\ 12-15, " & \ldots \ldots \ldots \ldots \ldots \ldots & 1.50 & 12.50\end{array}$


DECIDUOUS SHRUBS AND TREES-(Continued):

\section{BERBERIS thunbergi atropurpurea, Redleaf}

Japanese Barberry

Brilliant red foliage of early Spring fades to bronze red throughout the Sumnier and Autumn. Persistent scarlet berries. 4 feet.

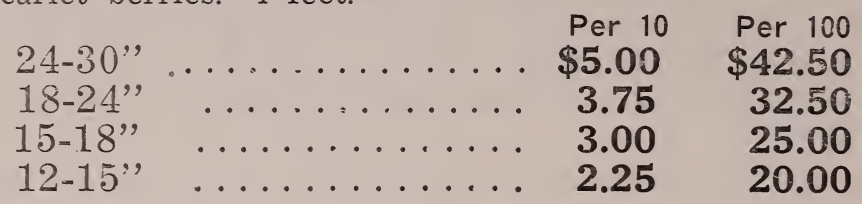

BRIDALWREATH-See Spirea prunifolia plena

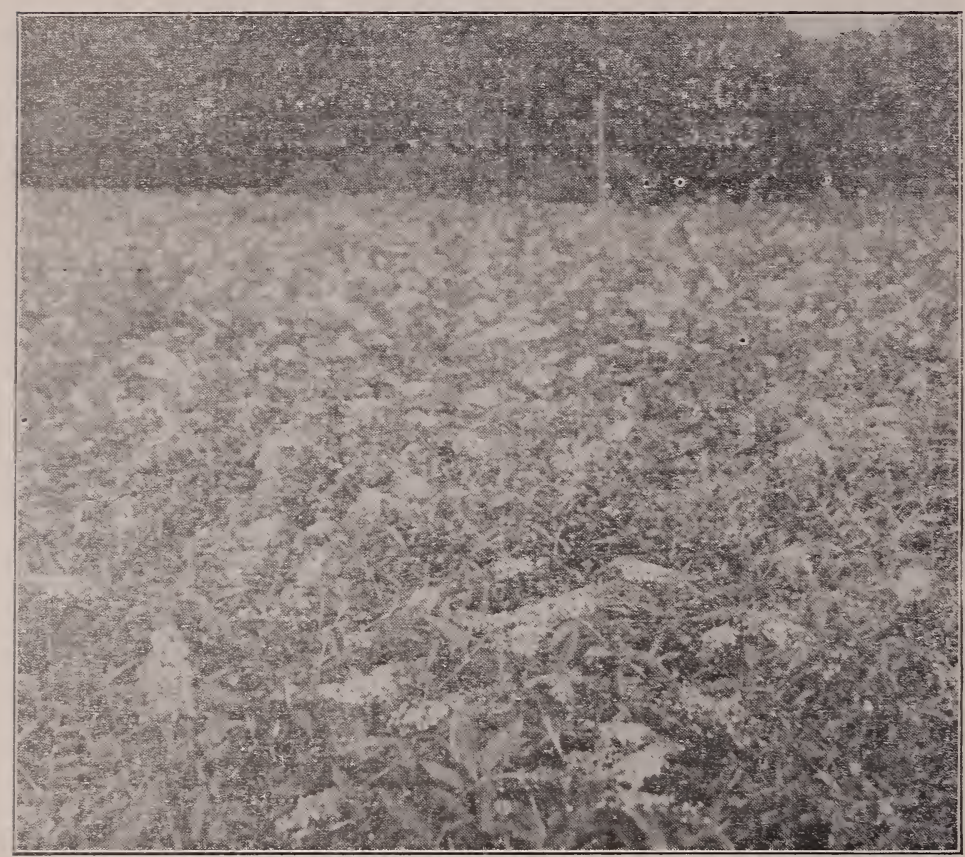

Well Grown Butterfiybush

BUDDLEIA "Charming", Pink Butterflybush

Strong erect grower, bearing long spikes of clear distinct pink blooms. 8 feet.
2-Year No. 1
3.00
25.00
2-Year Medium
2.25
20.00

davidi magnifica, Oxeye Butterflybush

The old favorite Butterflybush whose graceful purplish spikes of bloom appear from June through late Summer. 5 feet.

2-Year No. 1

2-Year Medium 
DECIDUOUS SHRUBS AND TREES-(Continued):

\section{CALYCANTHUS floridus, Sweetshrub}

Deep green glossy foliage. Handsome erect habit of growth. Likes the shade. Dark fragrant plum colored flowers in Spring. 7 feet.

$\begin{array}{llll}30-36, " & \ldots \ldots \ldots \ldots \ldots \ldots \ldots & \begin{array}{l}\text { Per } 10 \\ \mathbf{5 . 0 0}\end{array} & \text { Per } 100 \\ 24-30, & \ldots \ldots \ldots \ldots \ldots \ldots & \mathbf{4 . 0 0} & \\ 12-18, & \ldots \ldots \ldots \ldots \ldots \ldots & \mathbf{2 . 5 0} & \$ 20.00\end{array}$

\section{CERCIS canadensis, American Redbud} (Judas Tree)

One of our loveliest native trees, producing in early Spring a mass of rosy pink flowers. Most of our plants are tree form, but we could supply bush form should you desire. 25 feet.

$$
\begin{aligned}
& 6-8, \ldots \ldots \ldots \ldots \ldots \ldots . . \ldots 00
\end{aligned}
$$

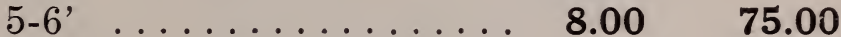

$$
\begin{aligned}
& 4-5, \quad \ldots \ldots \ldots \ldots \ldots \ldots \ldots \quad 5.50 \quad 50.00
\end{aligned}
$$

\section{chinensis, Chinese Redbud}

For use where the more familiar Canadensis is too large, this dwarf shrub produces masses of large dark flowers. Comparatively unknown but a very valuable plant. 8 feet.
$4-5$
15.00
$3-4^{\prime}$ 10.00
$2-3$
7.50

CHAENOMELES-See Cydonia japonica

CHERRY, Flowering-See Prunus cerasus

CHERRY, Weeping-See Prunus subhirtella

CHINESE ELM-See Ulmus pumila

CORNUS alternifolia, Pagoda Dogwood

Large shrub or small tree with horizontal growing branches slightly upturned at the tip which gives the tree its name. Produces large heads of lacy white flowers followed by glossy dark blue berries. 20 feet.
$6-8$ B\&B ........ 60.00
$5-6$, B\& $B \ldots \ldots \ldots \ldots . . .40 .00$
$4-5$, B\&B ........ 30.00

\section{DOGWOOD SPECIMENS}

We have available a few superb plants of:

Cornus florida

Cornus florida plena

Cornus florida rubra

These trees are up to eight feet in height, of good caliper (up to $3 \frac{1}{2}$ " and 4"), and loaded with bloom buds. Priced upon request. 
DECIDUOUS SHRUBS AND TREES-(Continued):

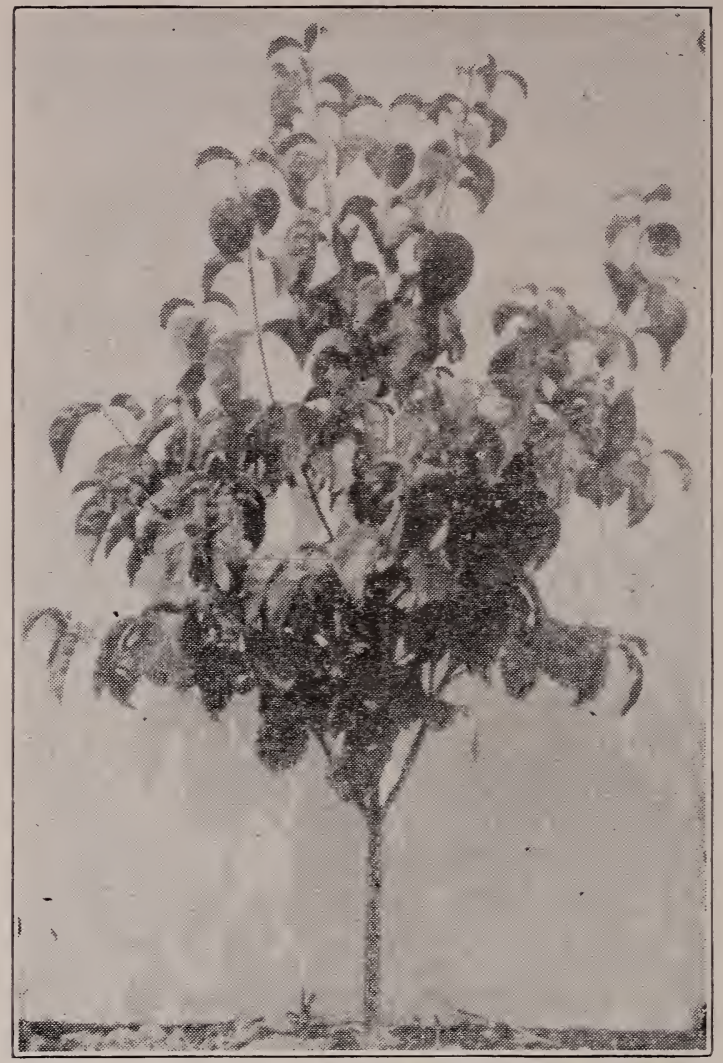

Beautiful Red Dogwood. Budded on Transplanted Seedilings

\section{CORNUS florida, White Flowering Dogwood}

The loveliest of all native American trees. Graceful symmetrical grower, equaily at home in the sun or partial shade. Bright red berries in winter. 25 feet.

$$
\text { Per } 10 \text { Per } 100
$$

$4-5$, B\&B ......... \$30.00 \$250.00

3-4' Bare Root ........ $16.00 \quad 150.00$

2-3' Bare Root ........ $12.00 \quad 100.00$

\section{florida plena, Doubleflowering Dogwood}

One of the most beautiful of the Dogwcods. Its double showy white flowers appear about ten days later than those of Florida, thus prolonging the Dogwood blooming season. 'Irees produce flowers at an early age. 20 feet.

$$
\begin{aligned}
& 5-6, \quad \text { B\&B ........ } 60.00 \\
& \text { 4. 5' B\&B ........ } 50.00 \\
& \text { 3- 4' Bare Root ...... } 30.00 \\
& \text { 2- 3' Bare Root ...... } 20.00 \\
& \text { 18-24" Bare Root ...... } 15.00
\end{aligned}
$$


DECIDUOUS SHRUBS AND TREES-(Continued):

CORNUS florida rubra, Redflowering Dogwood Beautiful single, deep pink flowers give this well shaped tree an unusual effect. Blooms in early Spring. Thrives in the sun or partial shade. 20 feet.

Per 10 Per 100

$5-6, \mathrm{~B} \& \mathrm{~B} \ldots \ldots \ldots \ldots . \$ 65.00 \$ 600.00$

4- 5' B\&B ........ $50.00 \quad 450.00$

3- 4' Bare Root ...... 27.50 250.00

2- 3' Bare Root ...... $17.50 \quad 150.00$

18-24" Bare Root ..... $15.00 \quad 125.00$

NOTE: Trees quoted above were budded on twoyear transplanted seedlings, have a magnificent root system, are well calipered and have a robust, well branched top.

NOTE: B\&B schedule to deduct from above prices if plants quoted B\&B are desired bare root, puddled.

$$
\begin{array}{r}
5-6, \ldots \ldots \ldots \ldots \ldots \ldots \ldots \\
4-5, \ldots \ldots \ldots \ldots \ldots
\end{array}
$$

sanguinea, Bloodtwig Dogwood

Upright shrub with dark green foliage and creamy white flowers, which are followed by clusters of dark berries. Attractive dark red branches in winter. 10 feet.

$\begin{array}{rlll}2-3, & \ldots \ldots \ldots \ldots \ldots \ldots \ldots & 3.00 & 25.00 \\ 18-24, & \ldots \ldots \ldots \ldots \ldots \ldots & 2.50 & 20.00\end{array}$

stolonifera, Red-Osier Dogwood

Spreads by suckers into a large mass. Twigs are blood-red, fall fruits are white. 8 feet.

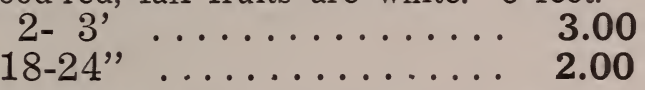

15.00

\section{CRABAPPLE, Flowering-See Malus}

CRAPEMYRTLE-See Lagerstroemia indica

CYDONIA japonica (Chaenomeles lagenaria),

\section{Flowering Quince}

Rugged thorny shrub bearing a mass of pink to red flowers in early Spring. Small fragrant fruits in Fall. 6 feet.

$\begin{array}{rrrr}2-3^{3}, & \ldots \ldots \ldots \ldots \ldots \ldots \ldots & 4.00 & 35.00 \\ 18-24, & \ldots \ldots \ldots \ldots \ldots \ldots & 3.00 & 25.00 \\ 12-18, & \ldots \ldots \ldots \ldots \ldots \ldots & 2.00 & 15.00\end{array}$

DEUTZIA scabra floraplena rosea,

Double Rose Deutzia

Strong erect grower. Profuse bloomer bearing double pink flowers over a long period in the Spring. 12 feet.

$\begin{array}{rrrr}3-4, & \ldots \ldots \ldots \ldots \ldots \ldots \ldots & 3.50 & 30.00 \\ 2-3, & \ldots \ldots \ldots \ldots \ldots \ldots & 2.50 & 22.50 \\ 18-24, & \ldots \ldots \ldots \ldots \ldots \ldots & 2.00 & 15.00\end{array}$


DECIDUOUS SHRUBS AND TREES-(Continued):

\section{DEUTZIA scabra, Pride of Rochester}

Tall grower. Flowers are large double white. One of the old favorite shrubs. 12 feet.

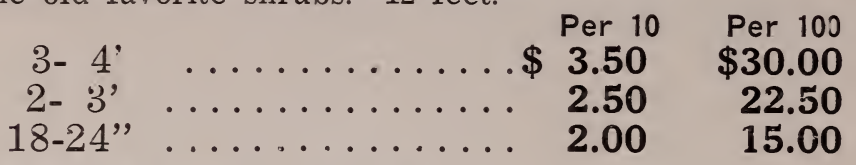

DOGWOOD-See Cornus

EXOCHORDA racemosa (Grandiflora), Pearlbush

A tall growing shrub covered in early spring by shiny waxy white blossoms. Attractive light green foliage. Excellent screen plant for open sun. 10 feet.

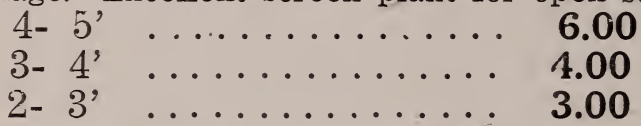

FORSYTHIA spectabilis, Showy Border Forsythia

Hardiest of all Forsythias and a very profuse bloomer, being covered from base of stem to tips with bright yellow flowers. Miost free flowering and popular variety. 8 feet.
4- 5
5.00
45.00
3- 4'
3.50
30.00
2- 3'
2.50
$18-24^{\prime \prime}$
2.00
22.50
15.00

\section{"Spring Glory", Yellow Forsythia}

This plant is said to be the finest of all the Forsythias. An extremely free bloomer. Its pale yellow flowers completely covering the branches from the ground line out to the furthermost tips. It is pale yellow in color, not quite so gaudy as the other Forsythias in more common use.
4- 5
6.00
3- 4'
4.50
$2-3^{\prime}$
3.50
50.00
18-24"
2.50
40.00
30.00
20.00

viridissima, Greenstem Forsythia

Bright green foliage and stems. Somewhat spreading habit of growth. Bright yellow flowers in March. 6 feet.
3- 4'
3.50
30.00
2- $3^{\prime}$
2.50
20.00
18-24"
2.00
15.00 I personally told many people where they could be obtained."

NEW YORK, Oct. 13, 1949: "The material arrived and is very 
DECIDUOUS SHRUBS AND TREES-(Continued):

HALESIA carolina (tetraptera), Carolina Silvert,ell

Attractive large shrub with rich yellow fall foliage. Snowy white beli-shaped flowers borne in Spring on branchlets. Seed pods are attractive winged burrs. 20 feet.

$$
\begin{aligned}
& 3-4, \quad \ldots \ldots \ldots \ldots \ldots \$ 6.00 \\
& 2-3, \quad \ldots \ldots \ldots \ldots \ldots \ldots \quad \mathbf{5 . 0 0} \$ \$ 45.00 \\
& 18-24 " \ldots \ldots \ldots \ldots \ldots \ldots 4.00 \quad 35.00
\end{aligned}
$$

HEDGING-See Index

HIBISCUS syriacus, Althea, Double Flowering

Vigorous upright shrubs useful in mass and background planting for screens. Flowers freely from late June until frost, in a wide range of colors from pure White to Purple. A favorite shrub. 10 feet to 12 feet.

VARIETIES:

Anemonaefiorlis (Pink)

Ardens (Violet)

Banner (White, red center)

Jeanne d'Arc (Pure White)

Lucy (Reci)

Purpurea semi-plena (Semi-double purple)

\section{Bush Form}

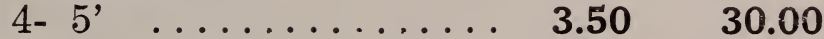

$$
\begin{aligned}
& 3-4, \ldots \ldots \ldots \ldots \ldots \ldots 2.50 \quad 22.50 \\
& 2-3^{\prime} \ldots \ldots \ldots \ldots \ldots . . . \ldots 2.00 \quad 15.00 \\
& 18-24 " \ldots \ldots \ldots \ldots \ldots . \ldots 1.25 \quad 10.00
\end{aligned}
$$

\section{Tree Form}

$$
\begin{array}{lllll}
5-6 & \ldots \ldots \ldots \ldots \ldots \ldots & \ldots \ldots & 6.00 & 50.00 \\
4-5^{\prime} & \ldots \ldots \ldots \ldots & \ldots \ldots \ldots & 4.50 & 40.00 \\
3-4 & \ldots \ldots \ldots \ldots & \ldots \ldots & 3.50 & 30.00
\end{array}
$$

syriacus, Althea, Single Flowering

The single varieties form a distinct and lovely family of the Althea. Their flowers, when wide open, strongly resemble the Hibiscus. Their colors are very bright and are enhanced by the yellow stamens and pistils.

$$
\begin{aligned}
& 3-4^{\prime} \ldots \ldots \ldots \ldots \ldots \ldots . \ldots 4.00 \quad 35.00 \\
& 2-3, \quad \ldots \ldots \ldots \ldots \ldots \ldots \ldots .3 .0 . \ldots \\
& 18-24 " \ldots \ldots \ldots \ldots \ldots . \ldots 2.00 \quad 15.00
\end{aligned}
$$

\section{VARIETIES:}

Coelestis (Blue) (2-3' largest available) Snowdrift (White)

Rubis (Red)

HONEYSUCKLE, Bush-See Lonicera

HONEYSUCKLE, Vines-See Vines 
DECIDUOUS SHRUBS AND TREES-(Continued):

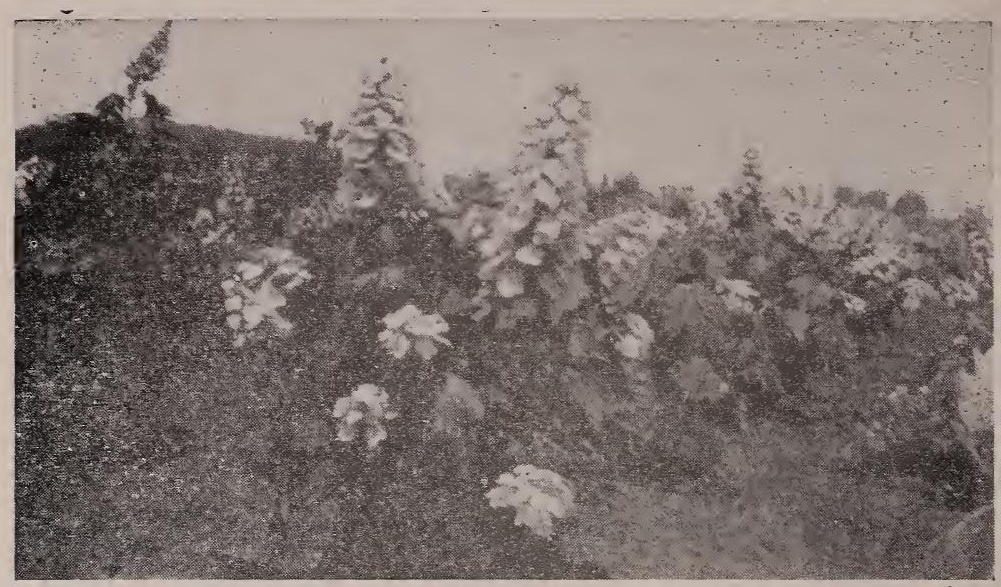

Oakleaf Hydrangea-One of the Best Shrubs.

HYDRANGEA quercifolia, Oakleaf Hydrangea

One of the most attractive native shrubs. Its heavy deep-lobed leaves resemble the Oak family and are highly colored in the Fall. Large spikes of white flowers, pink tinged, are borne in great profusion in late Spring and early Summer. Equally at home in the sun or partial shade. Develops into a large clump. 10 feet.

$$
\begin{array}{lll}
30-36 ", & \ldots \ldots \ldots \ldots \ldots \ldots \$ 8.00 & \$ 75.00 \\
24-30 " & \ldots \ldots \ldots \ldots \ldots & 6.50
\end{array}
$$

petiolaris (Schizophragma hydrangeoides), Climbing Hydrangea-See Vines

\section{HYPERICUM frondosum (aurem),}

Golden St. Johnswort

An attractive shrub with oblong bluish-green leaves, having bright yellow flowers. 5 feet.

$$
\begin{array}{llll}
18-24^{\prime \prime}, \ldots \ldots \ldots \ldots \ldots \ldots \ldots & 2.50 & 20.00 \\
12-18, & \ldots \ldots \ldots \ldots \ldots \ldots & 1.75 & 15.00
\end{array}
$$

moserianum, St. Johnswort

Dense low-growing shrub with attractive blue-green foliage and bright yellow summer flowers. Excellent border shrub. 3 feet.

$$
\begin{array}{llll}
18-24 ", \ldots \ldots \ldots \ldots \ldots \ldots \ldots & 6.00 & 50.00 \\
15-18, " \ldots \ldots \ldots \ldots \ldots & 4.50 & 40.00 \\
12-15, & \ldots \ldots \ldots \ldots \ldots \ldots & 3.50 & 30.00
\end{array}
$$

\section{prolificum, Shrubby St. Johnswort}

Develops into a large bushy shrub, quite dense in habit. Bright yellow flowers. 6 feet.

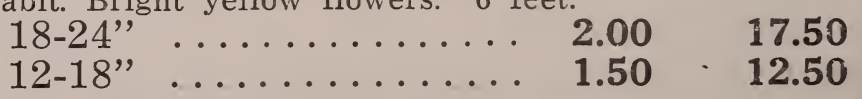


DECIDUOUS SHRUBS AND TREES-(Continued):

\section{KOLKWITZIA amabilis, Beautybush}

Handsome shrub of graceful habit, bearing a great profusion of Deautiful pink trumpet shaped flowers in the Spring. 8 feet.

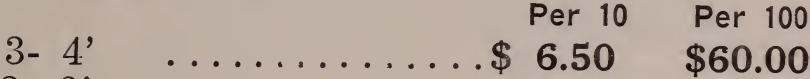

$$
\begin{aligned}
& 2-3, \ldots \ldots \ldots \ldots \ldots \ldots .5 .50 \\
& 18-24 " \ldots \ldots \ldots \ldots \ldots .4 .50
\end{aligned}
$$

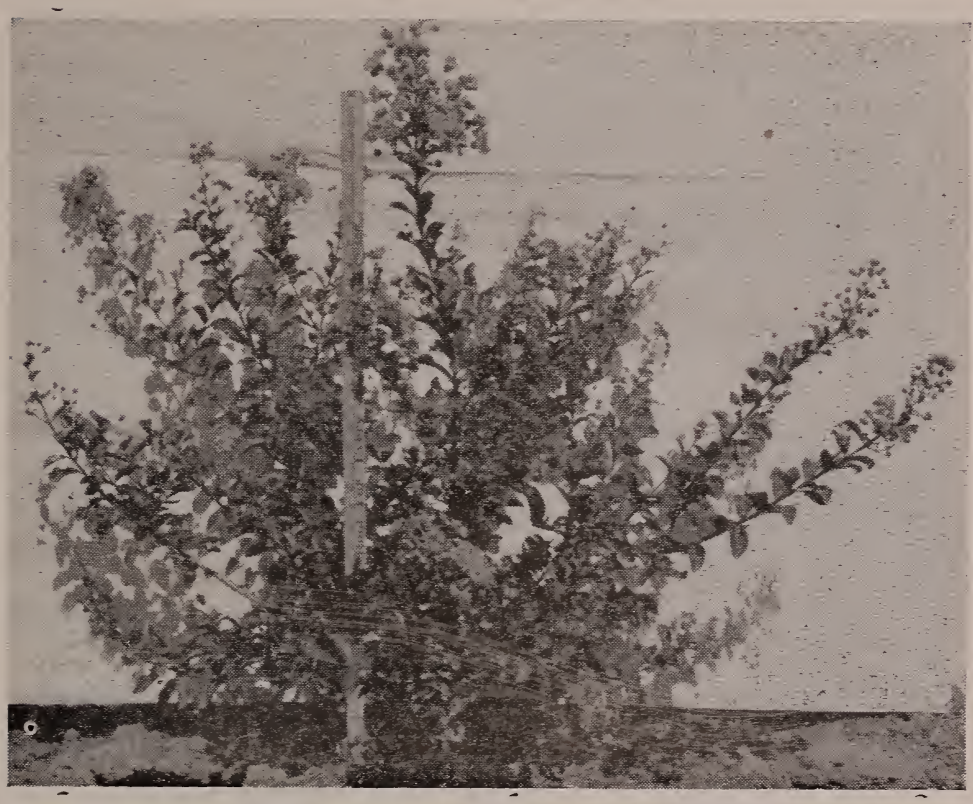

William Toovey Crapemyrtle-Beautıful Watermelon Red, Profuse Bloomer

\section{LAGERSTROEMIA indica, Crapemyrtle}

Crapemyrtle is the wonderful Summer blooming shrub of the South. Hardy as far north as Baltimore. Attractive deep green glossy leaves and masses of crapelike flowers from July through September. 20 feet.

Lavender (2-3' largest available)

Purple (2-3' largest available)

Red (18-24" largest available)

White

$3-4, \ldots \ldots \ldots \ldots \ldots$

2- 3 '

5.00

45.00

$18-24$,

$12-18 "$

OREGON, Oct. 15, 1949: "Thanks for your several letters of October 8 th and 10th and the order acknowledgement on the Magnolias. We certainly like the way you people do business and it would be a great pleasure if we could have more nursery firms in the industry of the same caliber as yours."

TEXAS, Oct. 15, 1949: "Your prices on Abelia are a little higher than some other quotations that we have had but we want Chase quality and grading." 
DECIDUOUS SHRUBS AND TREES-(Continued):

\section{LAGERSTROEMIA indica, Crapemyrtle}

William Toovey

The finest of all the Crapemyrtles. Neat, compact habit; producing a solid mass of beautiful deep watermelon red flowers in large heads. The most prolific bloomer and the most arresting color. 15 feet.

$$
\begin{aligned}
& 3-4{ }^{\prime} \quad \ldots \ldots \ldots \ldots \ldots \ldots \mathbf{6 . 5 0} \$ \mathbf{\$ 5 5 . 0 0} \\
& 2-3, \ldots \ldots \ldots \ldots \ldots \ldots \mathbf{5 . 0 0} \quad \mathbf{4 5 . 0 0} \\
& 18-24 " \ldots \ldots \ldots \ldots \ldots \ldots 4.00 \quad 35.00
\end{aligned}
$$

LILAC_-See Syringa

\section{LONICERA fragrantissima, Winter Honey-} suckle

Strong grower, whose fragrant creamy white flowers appear very early in the Spring. Handsome luxuriant foliage. 8 feet.

$$
\begin{array}{rrrr}
2-3, & \ldots \ldots \ldots \ldots \ldots \ldots \ldots & 3.50 & 30.00 \\
18-24, & \ldots \ldots \ldots \ldots \ldots \ldots & 2.75 & 22.50 \\
12-18, & \ldots \ldots \ldots \ldots \ldots \ldots & 2.00 & 15.00
\end{array}
$$

korolkowi, Blueleaf Honeysuckle

Attractive shrub with horizontal branches developing into a large mass. Fine blue leaves give the plants an unusual effect. Small flowers are pink, berries are bright red. 10 feet.

$$
\begin{array}{rrrr}
3-4, & \ldots \ldots \ldots \ldots \ldots \ldots \ldots & 6.00 & \\
2-3,, \ldots \ldots \ldots \ldots \ldots \ldots & 4.50 & 40.00 \\
18-24, & \ldots \ldots \ldots \ldots \ldots \ldots & 3.50 & 30.00 \\
12-18, & \ldots \ldots \ldots \ldots \ldots \ldots & 2.50 & 20.00
\end{array}
$$

NOTE: A word about Honeysuckles: The following varieties have been found to be highly effective as real dual purpose shrubs. Beside their masses of beautiful blooms, they make excellent snow fences when planted as hedges. Further to their credit, these snow fences serve as wonderful game cover.

\section{morrowi, Morrow Honeysuckle}

True spreading type with dark green leaves, creamy white flowers. 8 feet.

$$
\begin{array}{rrrr}
3-4, & \ldots \ldots \ldots \ldots \ldots \ldots \ldots & 3.00 & 25.00 \\
2-3^{\prime}, & \ldots \ldots \ldots \ldots \ldots \ldots & \mathbf{2 . 2 5} & 20.00 \\
18-24 & \ldots \ldots \ldots \ldots \ldots \ldots & 1.75 & 15.00
\end{array}
$$

\section{ruprechtiana, Manchurian Honeysuckle}

Hardy upright shrub with silvery white flowers in late Spring. Red orange berries in Fall. Bright clean foliage. 10 feet.

$\begin{array}{rrrr}3-4, & \ldots \ldots \ldots \ldots \ldots \ldots \ldots & 3.00 & 25.00 \\ 2-3, & \ldots \ldots \ldots \ldots \ldots \ldots & 2.25 & 20.00 \\ 18-24, & \ldots \ldots \ldots \ldots \ldots \ldots & 1.75 & 15.00\end{array}$

MICHIGAN, Oct. 21, 1949: "Enclosed please find 28c in stamps in payment of postage for our order No. 207. Thank you for the orompt service."

INDIANA, Oct. 24, 1949: "The trees arrived in satisfactory condition. Thanks." 
DECIDUOUS SHRUBS AND TREES-(Continued):

\section{LONICERA tatarica alba, White Tatarian Honeysuckle}

Tall growing and hardy, bearing white flowers followed by red berries. 10 feet.

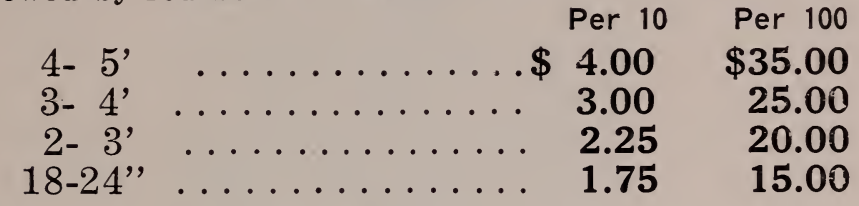

\section{tatarica rosea, Pink Tatarian Honeysuckle}

Vigorous grower. Light pink flowers in the early Spring followed by scarlet berries. $\delta$ feet.
$3-4, \ldots \ldots \ldots \ldots . . .60$
25.00
$2-3$
2.25
20.00
$18-24$ ',
1.75
15.00

\section{tatarica rubra, Red Tatarian Honeysuckle}

A strong growing Tatarian Honeysuckle whose bloom is almost a deep red. Attractive dark green foliage. The famous Wheeling strain.
2- 3
2.25
20.00
$18-24, " \ldots \ldots \ldots \ldots \ldots \ldots$
15.00
$12-18 "$
1.25
10.00

\section{tatarica zabelli, Zabel's Red Honeysuckle}

A handsome erect Honeysuckle with bright clean foliage and dark red flowers followed by a good crop of bright rea berries. The best of the Red Tatarian Honeysuckies. 8 feet.
$2-3$
4.00
35.00
$18-24^{\prime \prime}$
2.75
22.50
$12-18^{\prime}$
2.00 17.50

MISSOURI, Oct. 21, 1949: "The Barberry and California Privet are grand. Thanks."

TENNESSEE, Oct. !22, 1949: “Thanks again Henry for giving me such good efficient service in the car of evergreens you shipped us. When we unloaded it we found everything in good condition."

VIRGINIA, Oct. 26, 1949: "All items in the order were fine specimens and in good condition."

TEXAS, Oct. 27, 1949: "I appreciate very much your thinking of me on these plants. Our past dealings have been satisfactory and I still think of the hospitality you folks showed my family while at your place a little over a year ago."

ARKANSAS, Oct. 28, 1949: "Order received in good condition. Thanks for your prompt attention."

ILLINOIS, Oct. 31, 1949: "The conifer liners recently received are very nice stock."

ILLINOIS, Nov. 1, 1949: "This is to inform you that the liners did arrive in good condition and they are very nice." nice."

MISSISSSIPPI, Nov. 2, 1949: “The plants last year were very 
DECIDUOUS SHRUBS AND TREES-(Continued):

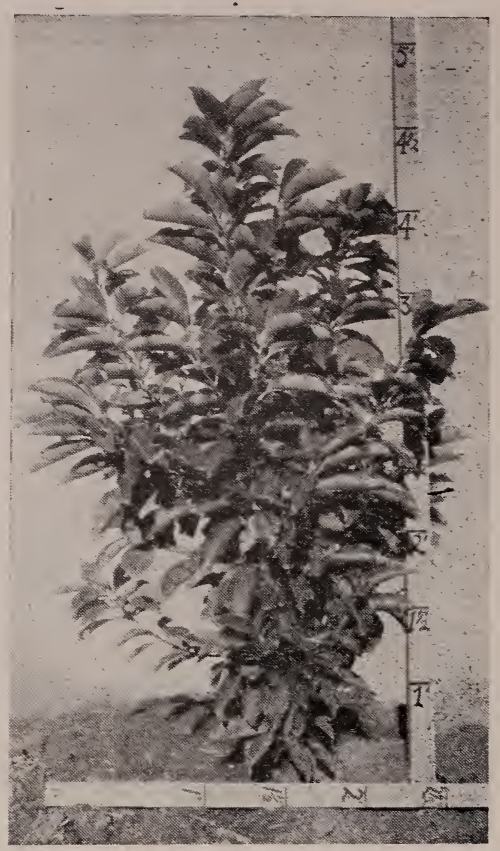

Magnolia sculangeana-One of our Specialties

\section{MAGNOLIA liliflora nigra, Purple Lily Magnolia}

Large shrub or small tree bearing beautiful flowers which are purplish, almost black, in the bud, opening to a deep purplish red. Blooms somewhat later than Soulangeana and in the South it is far less likely to be blasted by January and February cold snaps. 12 feet.

\begin{tabular}{|c|c|c|}
\hline & Per 10 & Per 100 \\
\hline $\begin{array}{c}3-4, \quad \text { B\& B } \\
3-3\end{array}$ & $\$ 37.50$ & $\$ 350.00$ \\
\hline $\begin{array}{ll}30-36, & \text { В } \\
24-30 & \text { B }\end{array}$ & $\begin{array}{l}32.50 \\
27.50\end{array}$ & $\begin{array}{l}300.00 \\
250.00\end{array}$ \\
\hline
\end{tabular}

\section{soulangeana, Saucer Magnolia}

The well known shrub Magnolia whose fragrant blooms appear before the leaves. Symmetrical upright grower of excellent habit. Flowers open light purple at base, shading to pink at tips, with inside of petals clear pink to white. One of our most beautiful ornamentals. 20 feet.

$\begin{array}{rrrr}6-8, & \text { B\&B } \ldots \ldots \ldots \ldots \ldots \ldots & \mathbf{6 7 . 5 0} & \mathbf{6 2 5 . 0 0} \\ 5-6, \text { B\&B } \ldots \ldots \ldots \ldots \ldots . & \mathbf{5 7 . 5 0} & \mathbf{5 2 5 . 0 0} \\ 4-5, \text { B\&B } \ldots \ldots \ldots \ldots \ldots . & \mathbf{4 7 . 5 0} & \mathbf{4 2 5 . 0 0}\end{array}$

GEORGIA, Nov. 18, 1949: "Plants arrived in gọd condition and checked out o.k.",

WEST VIRGINIA, Nov. 18, 1949: "The above, to supplement the 45 I received from you about Oct. 16th, opened up in fine condition and were highly satisfactory." 
DECIDUOUS SHRUBS AND TREES-(Continued):

\section{MALUS, Flowering Crabapple}

Flowering Crabs are among the most lovely of the Spring flowering trees. Their range of color is wide and their show is brilliant. Many varieties have bronzy red leaves which add to their attractiveness beyond the blooming season and almost all have small apples which give color in the Fall.

\section{TREE FORM}

Aldenhamensis (Semi-double purple) 20 ieet. (4-5, largest available.)

Floribunda (Pink to White.) 25 feet. (5-6' largest available).

Floribunda atropurpurea (Furple) 25 feet.

Hopa (Fink) 20 feet.

Niedzwetzkyana (Red) 15 fect.

Per 10 Per 100

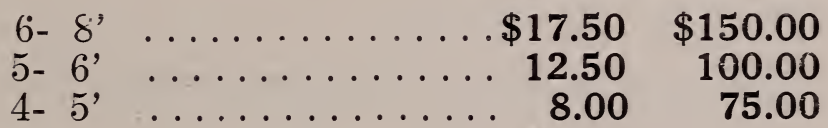

MIMOSA-See Albizzia julibrissin

PEACH FLOWERING-See Amygdalus

persica

\section{PHILADELPHUS Atlas, Giant Mock Orange}

This French hybrid Mock Orange is said to produce flowers almost 2" in diameter. It is hardy, has a good upright habit. 8 feet.
3- $4^{\prime}$
4.50
$2-3$
3.50
40.00
$18-24^{\prime}$
2.50
30.00
20.00

\section{coronarius, Sweet Mock Orange}

Handsome erect massive shrub, bearing a great profusion of fragrant white flowers in May and June, these flowers resembling Orange Blossoms. 10 feet.
4- 5
4.50
3- 4'
3.50
40.00
2- 3'
2.50
32.50
$18-24^{\prime \prime}$
1.50
20.00
10.00

\section{grandiflorus, Big Flowering Mock Orange}

A good erect grower covered with large white flowers in May and June. A very free bloomer, but has no fragrance. 12 feet.
4- 5
4.00
35.00
3- $4^{\prime}$
3.00
25.00
2- $3^{\prime}$
2.00
17.50
$18-24^{\prime \prime}$ 
DECIDUOUS SHRUBS AND TREES-(Continued):

\section{PHILADELPHUS virginalis (Virginaī),}

\section{Virginalis Mock Orange}

While not so vigorous a grower as the Coronarius and Grandiflorus, this Philadelphus is by far the most desirable of all, due to its exceptional blooming qualities. It blooms practically all summer long, with large waxy flowers, which have a delightful fragrance. The flowers produced on year-old wood are double while those produced on currently grown wood are single. One of the most desirable of all shrubs. A rather slow grower. 8 feet.

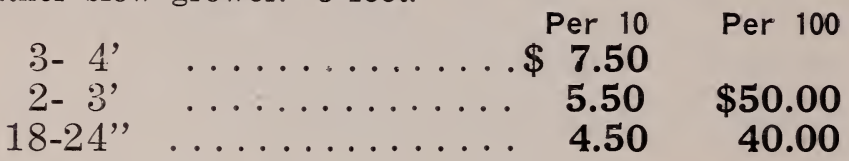

PRIVET-See Hedging

\section{PRUNUS glandulosa alboplena, White}

\section{Flowering Almond}

Showy broad shrub, completely covered in early Spring with beautiful white flowers. 5 feet.

2- 3' Budded on Plum. . $\mathbf{5 . 0 0}$

18-24" Budded on Plum .. 4.00

45.00

12-18" Budded on Plum. . 3.00

35.00

25.00

glandulosa sinensis, Pink Flowering Almond Beautiful early Spring flowering shrub, completely covered from the ground to the tip of the branches by a mass of pink blossoms. 5 feet.
24-30" Own Roots ......
18-24" Own Roots ...... $\mathbf{3 . 5 0}$
40.00
12-18" Own Roots ...... 2.50
30.00 20.00

\section{Newport, Newport Purple Plum}

A handsome semi-dwarf ornamental tree with bright bronzy red leaves, pink flowers and small red fruit. 8 feet.
5- 6' Budded on Plum. . $\mathbf{8 . 0 0}$
4- 5' Budded on Plum. . $\mathbf{6 . 5 0}$
3- 4' Budded on Plum.. $\mathbf{5 . 5 0}$
60.00
2- 3' Budded on Plum. . $\mathbf{4 . 5 0}$

\section{serrulata, Japanese Flowering Cherry}

Kwanzan, which we offer here, is the most favored of the upright Japanese Flowering Cherries. It is deep pink in color, with typical bright cherry foliage. 25 feet.

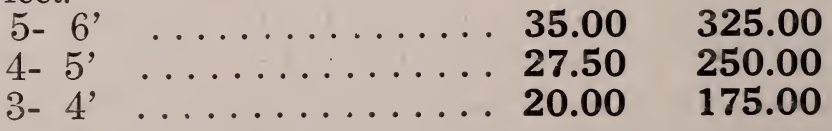

ILLINOIS, Nov. 26, 1949: "Again this season the plants were everything expected."

TEXAS, Nov. 29, 1949: "The shipment of Abelia was so good we need 2000 more." 
DECIDUOUS SHRUBS AND TREES-(Continued):

\section{PRUNUS subhirtella pendula, Japanese Weeping Cherry}

The beautiful, graceful Weeping Japanese Cherry which is so much admired by all who see it. The single is of more graceful habit than the double, and the flowers are a beautiful delicate single pink. The flowers on the double weeper are somewhat more showy but the habit of growth is not so graceful as in the single. 20 feet.

\section{SINGLE DOUBLE}

Per 10 Per 100

5- 6’' Stems No. 1 Heads $\$ 40.00 \$ 375.00$

\section{Thundercloud, Thundercloud Purple Leaf Plum}

We believe this to be the finest of all the purple leaf plums we have yet come across. It holds its bronzy purple throughout the entire season and not merely in the Spring. Upright strong grower. 25 feet.

4- 5' Budded on Plum.. 6.50

3- 4' Budded on Plum. . $\mathbf{5 . 5 0}$

2- 3' Budded on Plum.. 4.50

\section{triloba plena, Doubleflowering Plum}

One of our best ornamentals. This large shrub, or small tree, is literally covered with double pink flowers on showy slender branches in the Spring. 8 feet.

3- 4' Budded on Plum. 6.50

2- 3' Budded on Plum.. $\mathbf{5 . 0 0}$

18-24" Budded on Plum. . 4.00

12-18" Budded on Plum.. 3.00

QUINCE, Flowering-See Cydonia japonica

RED BUD-See Cercis

\section{RHODOTYPOS scandens (kerrioides), Black Jetbead}

Attractive spreading shrub with good light green foliage. Small white flowers of mid-summer are followed by jet-black berries in small clusters which hang on all winter. 6 feet.
$2-3$ packed and the roots were still good and moist. It is a pleasure to do business with a firm who will go to the trouble of returning $10 \mathrm{c}$ in stamps to make up for $50 \mathrm{c}$ credit for saving on packing charges. You may rest assured that from now on we will order all our nursery stock from you whenever you have it available and you can put us down as being a regular customer." 
DECIDUOUS SHRUBS AND TREES-(Continued):

\section{RHUS cotinoides, American Smoketree}

This is the Shittim Wood which legend says grew only on MIt. Sinai and from whose wood the Ark of the Covenant was made. It grows wild on Monte Sano in Madison County, Alabama, and is one of our loveliest native ornamentals. Old established plants when in bloom give the appearance of a brightly colored cloud of smoke. Its Fall foliage is of exceptionally bright color. 20 feet.

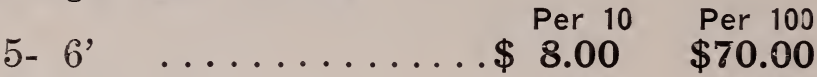

$$
\begin{aligned}
& 4-5, \ldots \ldots \ldots \ldots . \ldots . \ldots 00
\end{aligned}
$$

RHUS cotinus (Cotinus coggygria), Smoketree One of the prettiest of all flowering shrubs, and also one of the most unusual. Sometimes develcps into a small tree. The much branched panicles of flower are purplish to reddish in June and July and give the entire tree a most unusual smoke-like appearance.

15 feet.

\begin{tabular}{|c|c|c|c|}
\hline $4-5$ & & 12.50 & 100.00 \\
\hline $3-4^{\prime}$ & & 8.50 & 80.00 \\
\hline & & $\begin{array}{l}7.50 \\
6.50\end{array}$ & $\begin{array}{l}70.00 \\
60.00\end{array}$ \\
\hline
\end{tabular}

\section{ROBINIA hispida, Rose-Acacia Locust}

A slender hairy twigged erect shrub whose rosy flowers appear in panicles very much like Wisteria. Attractive compound leaves. 9 feet.
3- $4^{\prime}$
2- 3
4.50
$18-24^{\prime}$
3.50
2.50

\section{SALIX caprea, Goat Willow}

Erect growing, bright grayish green foliage on attractive bright green twigs. Spring catkins of bloom are much admired. 15 feet.
3- $4^{\prime}$
2- $3^{\prime}$
4.50
$18-24^{\prime \prime}$
3.50
2.50
30.00
20.00

\section{discolor, Pussy Willow}

The old favorite Willow, whose large early Spring catkins of bloom are so attractive. 20 feet.
2- 3'
3.50
$18-24^{\prime \prime}$
2.50
$12-18^{\prime \prime}$
1.50

SNOWBALL-See Viburnum opulus sterile SNOWBERRY---See Symphoricarpos

ALABAMA, Dec. 1, 1949: "Received the plants and many thanks for sending me nice ones. That is why I like to trade with you. I am always weil pleased with the plants."

CALIF́ORNIA, Dec. 5, 1949: "Answering yours of the 2nd, we are happy to say that the Dogwoods we received from you in 1948 did fine and were very satisfactory." 
DECIDUOUS SHRUBS AND TREES-(Continued):

\section{SPIREA arguta, Garland Spirea}

Upright form, very similar to thunbergi. Light green, lacy foliage. Solid mass of white bloom in the early Spring. 5 feet.

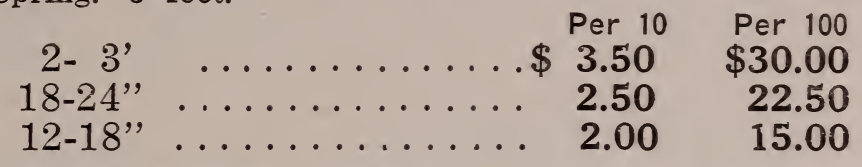

\section{froebeli, Froebel Spirea}

Excellent dwarf Spirea of somewhat similar habit of Anthony Waterer. Flowers are bright pink. Very vigorous and hardy. 4 feet.

$\begin{array}{llll}24-30, " & \ldots \ldots \ldots \ldots \ldots \ldots & 4.00 & 35.00 \\ 18-24,, \ldots \ldots \ldots \ldots \ldots \ldots & 3.00 & 27.50 \\ 15-18,, & \ldots \ldots \ldots \ldots \ldots \ldots & 2.25 & 20.00 \\ 12-15, " & \ldots \ldots \ldots \ldots \ldots \ldots & 1.75 & 15.00\end{array}$

\section{prunifolia plena, Bridalwreath}

The true old-fashioned Bridalwreath with small pure white blossoms borne in great profusion in early Spring. Glossy round leaves. Upright habit. 8 feet.

$\begin{array}{rlll}3-4, & \ldots \ldots \ldots \ldots \ldots \ldots \ldots & 4.50 & 40.00 \\ 2-3, & \ldots \ldots \ldots \ldots \ldots \ldots & 3.50 & 30.00 \\ 18-24, & \ldots \ldots \ldots \ldots \ldots \ldots & 2.50 & 20.00\end{array}$

\section{thunbergi, Thunberg Spirea}

Earliest blooming of all the Spirea, covered with tiny white blossoms. Graceful arching habit of growth, fine light green lacy foliage. 5 feet.

$$
\begin{array}{rlll}
2-3, & \ldots \ldots \ldots \ldots \ldots \ldots \ldots & 3.50 & 30.00 \\
18-24, & \ldots \ldots \ldots \ldots \ldots \ldots & 2.50 & 22.50 \\
12-18, & \ldots \ldots \ldots \ldots \ldots \ldots & 2.00 & 17.50
\end{array}
$$

\section{vanhouttei, Vanhoutte Spirea}

The most popular Spirea for massing. Covered in Spring by cluster's of pure white flowers. Vigorous grower with semi-drooping habit. 8 feet.

2- 3' Shrub ........ $\mathbf{2 . 5 0}$

18-24" Shrub ........ $1.75 \quad 15.00$

$12-18$ " Shrub . . . . . . $1.25 \quad 10.00$

vanhouttei, Vanhoutte Spirea Hedging-

See Hedging.

\section{SYMPHORICARPOS chenaulti, Improved}

Coralberry

Neat fine foliage on slender stems. Fruit is white with red spots. 5 feet.
3- 4' 
DECIDUOUS SHRUBS AND TREES-(Continued):

\section{SYMPHORICARPOS mollis, Spreading \\ Snowberry}

Graceful spreading branches carrying large 'snow white berries during Autumn. 4 feet.

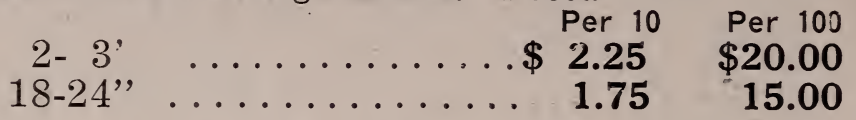

racemosus, Snowberry

Excellent plant for massing. Large white berries during Autumn. 4 feet.

2- 3 ,

2.25

$18-24, \ldots \ldots \ldots \ldots \ldots .1 .75$

20.00

15.00

\section{vulgaris, Coralberry (Indian Currant)}

Excellent bank retainer. Spreads by stolons. Heavy with coral berries in Winter. 4 feet.
2- 3 '
2.25
$18-24$,
1.75
20.00
15.00

SYRINGA, Mockorange-See Philadelphus

\section{SYRINGA chinensis (Rothomagensis),}

Chinese Lilac

Strong upright grower, good clean foliage. Single purplish red spikes of blooms in great profusion in Spring and another fair crop of blooms in late Summer. 10 feet.
2- 3'
4.00
35.00
18-24"
$12-18 "$
2.00
15.00

\section{vulgaris, Common Purple Lilac}

Old fashioned garden variety. Single bluish purple flowers. Thrives in partial shade. 12 feet.
18-24"
3.00
$12-18$
2.00

LOUISIANA, Nov. 30, 1949: "We have just received our order of Pinkflowering Dogwoods. We are so well pleased with these trees that we are ordering more along with the other stock."

ILLINOIS, Dec. 3, 1949: "Well here I am again. First I want to tell you that those 4-6", Pfitzers are the best growing little trees anyone would want to see for the first year. If we have a good growing season next year we will have plenty of 12-15", in finished stock."

KENTUCKY, Dec. 6 .1949: “Thank you for sending such nice stock."

MISSISSIPPI, Dec. 8, 1949: "Mighty fine plants. Better than samples you sent-a Chase habit I find. $\$ 420.83$ check enclosed."

SOUTH CAROLINA, Dec. 5, 1949: "The plants received from you last winter were excellent."

VIRGINIA, Dec. 12, 1949: "Shipment of plants received in excellent condition-all have been planted-check enclosed."

TEXAS, Dec. 15, 1949: "We received the plants as listed on your invoice dated Dec. 8th, in good shape and like them fine." 
DECIDUOUS SHRUBS AND TREES-(Continued):

\section{SYRINGA vulgaris, (Hybrid French Lilacs) Named Varieties}

Lilacs have long been great favorites everywhere. Their free flowering habit, easy culture, and great range of color makes them easily adaptable to almost any situation. 4 to 10 feet.

Abel Carriere (Dble. Dark Purple). Up to 2-3'.

Alphonse Lavallee (Dble. Pale Blue) Up to 18-24"

Bleuatre (Sgle. Blue) Up to 2-3'.

Chas. Joly (Dble. Rich Red) 12-18" only.

Chas. Tenth (Sgle. Red) Up to 2-3'.

Congo (Sgle. Red to Magenta) Up to 18-24".

Edmond Bossier (Sgle. Purple) Up to 18-24'.

Gen'1. Pershing (Dble. Bluish Lavender) Up to 2-3'.

Jan Van Tol (Sgle. White) 12-18" only.

Katherine Havemeyer (Dble. Pink to Lavender)

12-18" only.

Ludwig Spaeth (Sgle. Red) Up to 18-24".

Marr Micheli (Dble. Blue) Up to 2-3'.

Marecnal Foch (Sgle. Pink) 12-18" only.

Michel Buchner (Dble. Lavender to Blue) Up to $2-3$.

Monge (Sgle. Reddish Purple) 12-18" only.

Olivier de Serres (Dble. Blue) Up to 18-24".

President Grevy (Dble. Blue) Up to 18-24".

Waldeck Rousseau (Dble. Rosy Violet) Up to 2-3'.

(Budded on California Privet)

Per 10 Per 100

$2-3^{\prime} \quad \ldots \ldots \ldots \ldots \ldots \ldots . . . \$ 6.00 \quad \$ 50.00$

$18-24 " \ldots \ldots \ldots \ldots . \ldots . \ldots 40 . \ldots 40 . \ldots$

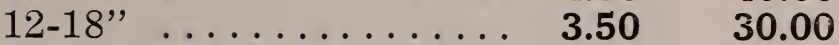

TAMARIX africana, African Tamarix

Green foliage, pink flowers in April. 15 feet.

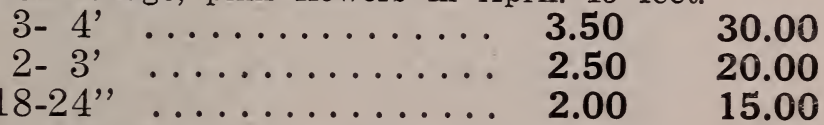

amurensis, Amur Tamarix

Attractive blue foliage, bright pink flowers in the Spring. 15 feet.
3- $4^{\prime}$
2- $3^{\prime}$
4.00
35.00
$18-24$
3.00
25.00
15.00

\section{gallica, French Tamarix}

Light pink flowers, green foliage. 10 feet.

3- 4' ........... 3.50

$2-3, \ldots \ldots \ldots \ldots \ldots . . \ldots . . \ldots$

30.00

$18-24^{\prime}$

2.00 
DECIDUOUS SHRUBS AND TREES-(Continued):

TAMARIX hispida aestivalis, Kashgar Tamarix

This is the best of all the Tamarix in that it is almost everblooming. Bright green foliage, pink fiowers that occur pretty well all along. 8 feet.

$$
\begin{aligned}
& \text { Per } 10 \text { Per } 100 \\
& \text { 2- } 3 \\
& \text { Per } 10 \\
& \$ 35.00 \\
& \text { 18-24" } \\
& 4.00 \\
& \text { 12-18', } \\
& 3.00 \\
& 25.00 \\
& 2.00
\end{aligned}
$$

\section{ULMUS pumila, Dwarf Elm (Chinese Elm)}

The rapid growing shade tree-probably the most rapid of all. Of course the best trees were dug out of here during our '49-'50 shipping season, but perhaps we can pick around and find some that would be fairly straight. We are still shrub growers and don't know much about the Chinese Elm Tree business, ex cept as seedlings. See L O stock for some honeys!
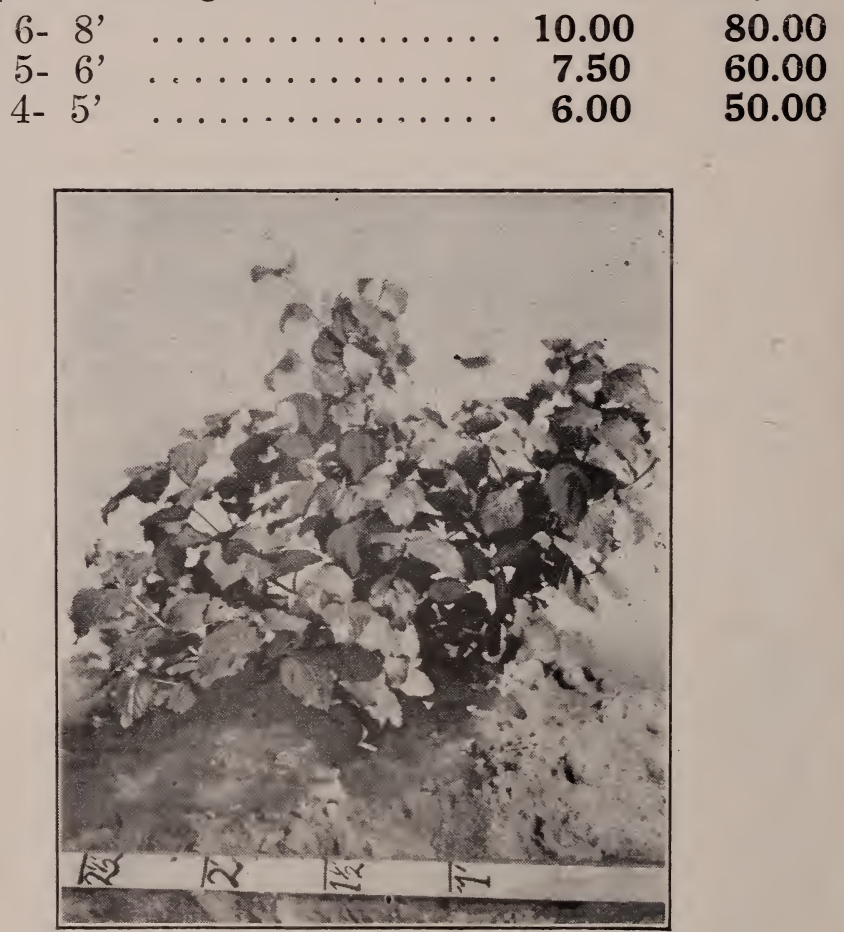

Viburnum carlesi-No other shrub like it.

\section{VIBURNUM carlesi, Mayflower Viburnum}

This is the most desirable of the entire large Viburnum family. Its mid-spring bloom is a beautiful pale pink with a waxy appearance carrying at delightful fragrance that is like no other shrub we have ever met. It has a distinct spicy aroma. Handsome bushy habit of growth. 5 feet.

30-36" B\&B Own Roots $40.00 \quad 375.00$ 24-30" B\&B Own Roots $35.00 \quad 325.00$ 
DECIDUOUS SHRUBS AND TREES-(Continued):

\section{VIBURNUM dentatum, Arrowwood}

Broad bushy shrub, bearing white heads of flowers in May. Blue-black berries are attractive in winter. Birds go for these berries in a big way. 10 feet.
3- $4^{\prime}$
Per 10
Per 100
$2-3^{\prime}$
4.50
$\$ 40.00$
$18-24$
3.50
30.00

\section{lantana, Wayfaring Tree}

Upright, vigorous shrub. White flowers followed by berries which are first red and then turn black. 15 feet.

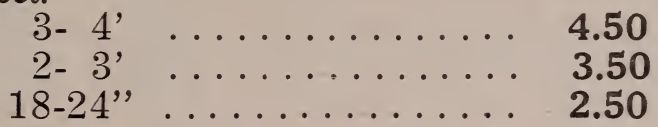

\section{cpulus sterile, Common Snowball}

The great old-time favorite of casy culture and good habit, covered in early Spring by balls of snow-white flowers. 9 feet.

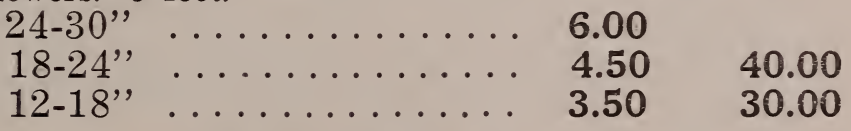

\section{tomentosum plicatum (sterile),}

\section{Japanese Snowball}

Another grand member of the Viburnum family. It is a strongly erect shrub with handsome deeply indented leaves. The perfectly snow white flowers completely cover the plant in late Spring. Flowers are round compact "Snowballs." 12 feet.
$3-4$
10.00
2- $3^{\prime}$
8.00
$18-24$ "
6.00

\section{VITEX macrophylla, Lilac Chaste Tree}

A graceful shrub with attractive spikes of lovely pale blue fiowers. Biooms very freely from July until Fall. A rather vigorous grower, produces its flowers on new wood. Foliage is shiny green, deeply indented. 10 feet.
4- 5'
5.00
45.00
3- 4 '
4.00
$2-3^{\prime}$
3.00
35.00
$18-24^{\prime \prime}$
2.25
25.00 20.00

WEIGELA Bristol Ruby (Plant Patent No. 492)

This Weigela is a tremendous improvement on the old Eva Rathke, being much hardier, has a much more vigorous habit of growth, and produces great clusters of beautiful red flowers, both Spring and Autumn. One of the very best of the new shrubs. 7 feet.
3- 4'
8.50
80.00
2- 3
6.50
60.00
18-24' 
DECIDUOUS SHRUBS AND TREES-(Continued):

\section{WEIGELA Eva Rathke}

A red Weigela. Medium height spreading shrub. Flowers are rich red, blooming in Spring and again in Autumn. 6 feet.

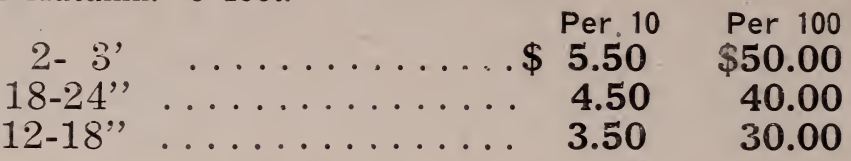

rosea, Pink Weigela

Vigorous spreading shrub with bright pink trumpet shaped flowers. Excellent mass plant. 8 feet.

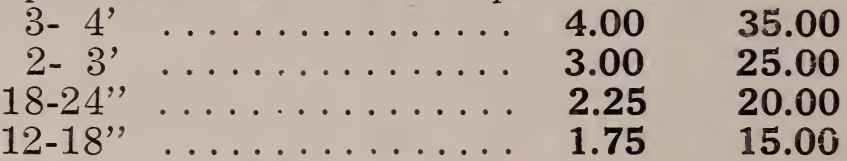

\section{vaniceki, Vanicek's Red Weigeía}

This is an "Improved" Eva Rathke. The plant is a very vigorous grower. It is very hardy having originated in Rhode Island and bears overwhelming masses of bright, ruby colored flowers in the Spring with a sparser bloom in the Fall. We believe it is one of the very best members of the Weigela family and that when it becomes better known it will be in terrific demand. Well worth while. 8 feet.

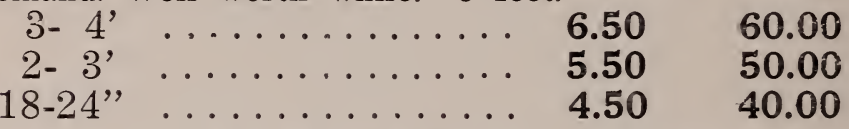

nana variegata, Dwarf Variegated Weigela

Compact grower. Pale pink flowers. Variegated leaves are green with sharply contrasting yellowishwhite margins. 5 feet.

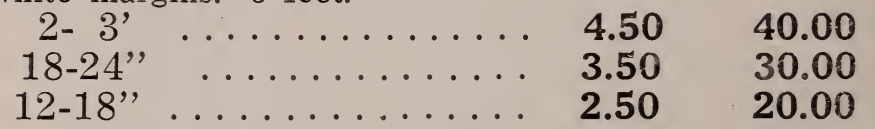

\section{CONIFERS}

All Conifers listed have been at ieast twice trans jlanted frequently root pruned and sheared. They $w 11$ be dug with a firm ball and securely burlapped at prices quoted. Five plants of a variety or grade at the ten rate, twenty-five at the hundred rate.

BIOTA-See Thuja orientalis

\section{JUNIPERUS chinensis pfitzeriana, Pfitzer Juniper}

The most widely used Evergreen known to the horticultural trade today. Spreading habit of growth, handsome gray-green foliage. Transplants easily and withstands all manner of abuse and hardship. 20-foot spread.

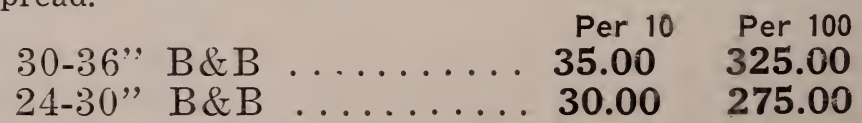




\section{CONIFERS-(Continued):}

JUNIPERUS communis fastigiata, Narrow Type Irish Juniper

Nuch like the old-fashioned Irish Juniper except that it is more compact, requiring no shearing to keep its handsome columnar shape. Fine foliage of good color. Erect and stately. 12 feet.

$\begin{array}{rrrr}3-4, & \text { Per } 10 & \text { Per } 100 \\ 30-36, & \text { B\&B } \ldots \ldots \ldots \ldots \ldots . \$ 25.00 & \mathbf{2 2 5 . 0 0} \\ 24-30, & \ldots \ldots \ldots \ldots & \mathbf{2 0 . 0 0} & \mathbf{1 7 5 . 0 0} \\ & \text { B\&B } \ldots \ldots \ldots \ldots .15 .00 & \mathbf{1 2 5 . 0 0}\end{array}$

\section{excelsa stricta, Spiny Greek Juniper}

Compact, symmetrical cone-shaped Juniper. Grayish green foliage. Very useful in formal effects. 6 feet.

$$
\begin{aligned}
& \text { Per } 10 \text { Per } 100 \\
& \text { 30-36" B\&B ........ } 32.50 \quad 300.00 \\
& \text { 24-30" B\&B ......... } 27.50 \quad 250.00
\end{aligned}
$$

\section{virginiana burki, Burk's Red Cedar}

Improved form of Silver Red Cedar, having much finer foliage and requiring but little shearing to remain compact. Good straight leader. Decorative blue berries in Winter. These are sheared specimens. 15 feet.

$$
\begin{array}{rrrrr}
3-4, & \text { B\&B } & \ldots \ldots \ldots \ldots \ldots & 42.50 & 400.00 \\
30-36, & \text { B\&B } & \ldots \ldots \ldots \ldots & 37.50 & 350.00 \\
24-30, & \text { B\&B } \ldots \ldots \ldots \ldots \ldots & 32.50 & 300.00
\end{array}
$$

virginiana carnarti, Cannarî's Red Cedar

The most popular form of the Red Cedar sports, having very beautiful rich green, heavily tufted foliage which holds a very fine Winter color. Bears blue and silver berries which remain late in Winter. These are sheared specimens. 15 feet.

$\begin{array}{rrrrr}3-4, & \text { B\&B } \ldots \ldots \ldots \ldots \ldots & 42.50 & 400.00 \\ 30-36, & \text { B\&B } \ldots \ldots \ldots \ldots . & 37.50 & 350.00 \\ 24-30, & \text { B\&B } \ldots \ldots \ldots \ldots \ldots & 32.50 & 300.00\end{array}$

virginiana glauca, Silver Red Cedar

Distinctive silvery-blue foliage. One of the most popular Red Cedar sports. Good dark blue berries in Winter. 20 feet.

$$
\begin{array}{llll}
30-36 ", & \ldots \ldots \ldots \ldots \ldots \ldots & \mathbf{3 7 . 5 0} & \mathbf{3 5 0 . 0 0} \\
24-30, & \ldots \ldots \ldots \ldots \ldots & \mathbf{3 2 . 5 0} & \mathbf{3 0 0 . 0 0}
\end{array}
$$

\section{virsiniana hilli, Hill's Dundee Red Cedar}

Very compact neat tree, maintaining an excellent conical shape with very little shearing. Its handsome grey-green foliage turns bronzy purple after the first frost. These are sheared specimens. 15 feet.

$\begin{array}{rrrrr}3-4 & \text { B\&B } & \ldots \ldots \ldots \ldots \ldots & 42.50 & 400.00 \\ 30-36, & \text { B\&B } & \ldots \ldots \ldots \ldots & 37.50 & 350.00 \\ 24-30, & \text { B\&B } & \ldots \ldots \ldots \ldots \ldots & 32.50 & 300.00\end{array}$


CONIFERS-(Continued):

THUJA orientalis (Biota) aurea nana, Berckman's Golden Arborvitae

Compact ,symmetrical, dwarf grower. Bright golden yellow foliage. One of the most popular of the Biotas. 5 feet.

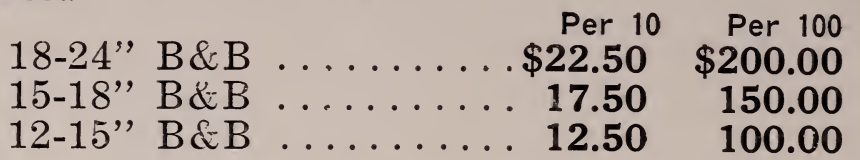

or. aurea nana globosa, Dwarf Golden Arborvitae

Dwarf globe form of Aurea Nana. Excellent for border entrance planting and urns. 2 feet.

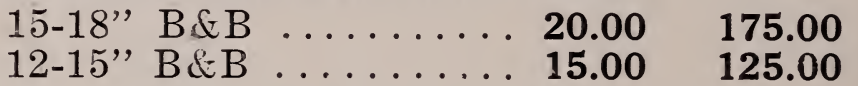

or. bakeri, Baker's Pyramidal

Arborvitae

One of the fine Biotas for the South. A tall compact column of bright green foliage. 10 feet.

24-30" B\&B ........ 22.50

18-24" B\&B ........ $17.50 \quad 150.00$

$15-18$ " B\&B ........ $12.50 \quad 100.00$

or. Chase's Golden, Chase's Golden Arborvitae

This is one of our selected seedlings of Biotas. Its habit of growth is erect somewhat in the way of $\mathrm{Au}$ rea Conspicua. Bright golden color. 15 feet.

$3-4^{\prime}$ B\&B ......... $32.50 \quad 300.00$

$30-36$, B\&B ........ 27.50 250.00

$24-30 ”$ B\& B ........ $22.50 \quad 200.00$

or. compacta, Compact Arborvitae

Pleasing dark green foliage. Somewhat columnar in growth. Not as tall and narrow as Bakeri. 6 feet.

18-24" B\&B ......... $17.50 \quad 150.00$

$15-18 ”$ B\&B ........ $12.50 \quad 100.00$

or. elegantissima, Yellow Column Arborvitae One of the most beautiful Evergreens in the Biota family. Pointed top, broad base, compact grower. Foliage is good clear gold. 15 feet.
24-30" B\& B ........ 22.50
18-24" B\&B ........ $17.50 \quad 150.00$
$15-18$ " B\&B ........ $12.50 \quad 100.00$

or. globosa, Chinese Globe Arborvitae

One of our own selections. Makes a somewhat loose natural globe. Light green foliage of fine texture. 4 feet.

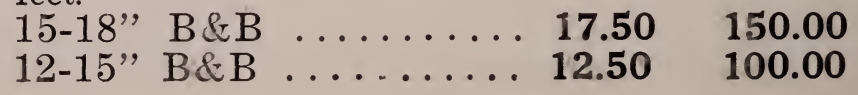




\section{BROADLEAVED EVERGREENS}

Items priced $\mathrm{B} \& \mathrm{~B}$ will be dug with a firm ball and securely burlapped at the prices quoted. Those priced bare root will be puddled in mud as dug, and packed in damp Sphagnum Moss for shipment. Below is a price schedule of B\&B. If you are willing to accept the risk of handling those items quoted $B \& B$ without balling you may deduct from our list price according to this schedule and if you prefer to have those plants priced NR, handled with a ball of earth and burlapped, you may add to the price list as per the schedule.

\section{B\&B SCHEDULE}

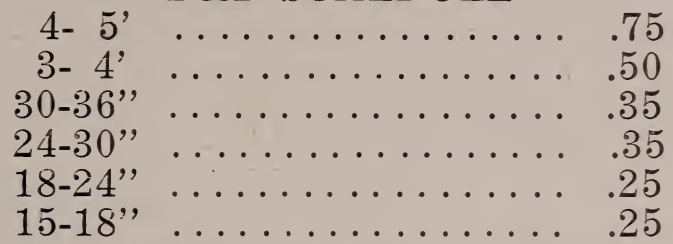

Five plants at the 10 rate, twenty-1ive plants at the 100 rate.

\section{ABELIA Edward Golicher, New Pink Abelia}

A startling introduction into the Broadleaved Evergreen family. Good compact spreading habit of growth. Fine foliage with a bronze tinge and large flowers of a distinct bright pink. Unusual and lovely. 4 foot spread.

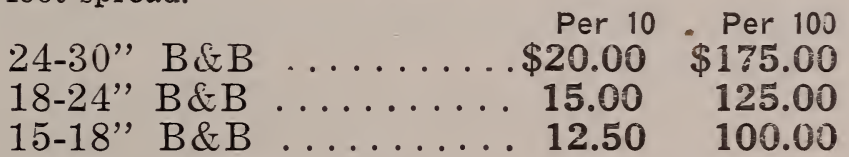

\section{grandiflora, Glossy Arbutus}

Glossy leaves on purplish-red stems. Pinkish white trumpet shaped flowers during the summer. Excellent border plant, hedge plant, or massing plant. 8 feet.
3- 4' N.R. . . . . . . 15.00
125.00
2- 3' N.R. . . . . . 12.00
100.00
18-24" N.R.
8.50
75.00
$15-18 "$ N.R.
6.00
50.00

\section{AZALEAS}

Through special arrangement with one of the best growers on the Del-Mar-Va Peninsula, we are offering this year, for the first time, the following Kurume Azaleas. These plants are compact, and have flower buds. They are well grown and stocky. They will be shipped direct from the Eastern Shore of Virginia, by freight, express or truck loads. No motor freight.

Hinodegiri, (Deep red flowers in clusters. The standard variety, by far the most popular Azalea.)

Snow, (Pure white, hose-in-hose)
$12-15 "$ B\&B ....... 17.50
160.00
$10-12$ ' B\&B ....... 14.00
125.00
8-10" B\&B ......... $12.00 \quad 100.00$
Deduct $10 \mathrm{c}$ per plant if burlap not required. 
BROADLEAVED EVERGREENS-(Continued):

\section{BAMBUSA viridi-glaucescens, Bamboo}

Our President, Mr. H. B. Chase, has a few clumps of

this nice plart in his back yard. He planted them as part of his hobby, but they are beginning to run away from him. They have begun to interfere with his Sunday morning back yard gardening, and he would like to part with them. They are too nice to throw away, and so we offer them here. They will develop into a good clean screen, or if you are a fisherman, will make you some dandy bream poles.

$$
\begin{array}{rr}
\text { 5- '7' Clumps N.R. . . . . \$12.50 } \\
\text { 4- 5' Clumps N.R. . . . } 10.00
\end{array}
$$

\section{BERBERIS mentorensis (U. S. Patent No. 99)}

\section{Mentor Barberry}

The new hedge Barberry which is so much admired. Drought resistant, tough and hardy. Naturally upright and dense, it requires very little attention and grows under almost all conditions. Its long thorns and dense growth makes a very effective barrier. Attractive glossy leaves clothe the entire plant from the tips of the branches to the ground line.

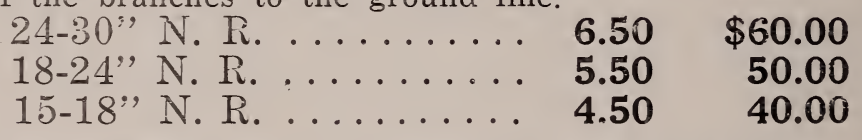

\section{ELAEAGNUS pungens fruitlandi, Fruitland's}

\section{Elaeagnus}

A fine strong growing broadleaved Evergreen whose leaves are large, pointed with a beautiful silvery cast ben,ath. 15 feet.

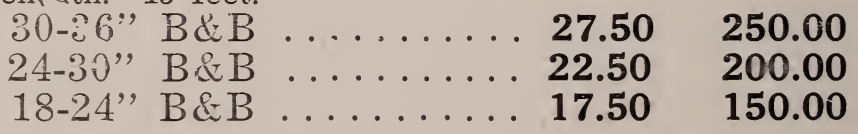

\section{EUONYMUS patens (Kiautschovicus),} Spreading Euonymus (Winterberry)

A compact shapely Evergreen shrub which will form a dense vine if given a little support. One of the most popular broadleaved Evergreens. Good foliage, bright berries. 4 feet.

$$
\begin{aligned}
& 24-30 " \text { B\&B ......... } 20.00 \quad 175.00 \\
& 18-24 \text { " В\&B ......... } 15.00 \quad 125.00 \\
& \text { 15-18" В\&B ........ } 10.00 \quad 75.00
\end{aligned}
$$

\section{radicans colorata, Spreading Wintercreeper}

Excellent ground cover for sun or shade. Long narrow leaves take on a bright bronze coloration in the Fall. 8-foot spread.

$$
\begin{aligned}
& 15-18 \text { " N.R. . . . . . . . } 2.75 \quad 25.00 \\
& 12-15 \text {, N. R. . . . . . . } 2.25 \quad 20.00 \\
& 8-12 \text { " N. R. ........ } 1.75 \quad 15.00
\end{aligned}
$$


BROADLEAVED EVERGREENS-(Continued):

\section{ILEX vomitoria, Yaupon Holly}

A very attractive shrub with spreading branches and small cval or oblong leaves. Small red berries are produced in great profusion. Makes a wonderful hedge plant. Plants offered here are very dense and compact. 20 feet.

\begin{tabular}{|c|c|c|}
\hline 24-30" B\&B & $\begin{array}{r}\text { Per } 10 \\
\$ 25.00\end{array}$ & $\begin{array}{r}\text { Per } 100 \\
\$ 225.00\end{array}$ \\
\hline $18-24 "$ В\&B & 20.00 & 175.00 \\
\hline
\end{tabular}

\section{LAUROCERASUS caroliniana, Cherry-Laurel}

Bright glossy green foliage. Grows compact and symmetrical. Easily sheared to any shape, useful for screens, hedges or as specimens. 15 feet.

NOTE: Plants offered here are strong one-year transplants which would probably handle safely without balling. We recommend them to your attention as hedge plants.

$18-24 "$ B\&B ........ $15.00 \quad 125.00$

$15-18$, B\&B ........ $12.50 \quad 100.00$

$12-15 "$ B\&B ........ $10.00 \quad 75.00$

\section{LIGUSTRUM japonicum, Japanese Privet}

The upright grower. Dark green large shiny leaves. Grows swiftly into a large dense shrub. Small white flowers are followed by clusters of blue berries. 20 feet.

$\begin{array}{lllll}4-5, & \text { B\&B } & \ldots \ldots \ldots \ldots \ldots & \mathbf{2 2 . 5 0} & \mathbf{2 0 0 . 0 0} \\ 3-4, & \text { B\&B } & \ldots \ldots \ldots \ldots \ldots & \mathbf{1 7 . 5 0} & \mathbf{1 5 0 . 0 0} \\ 2-3, & \text { B\&B } & \ldots \ldots \ldots \ldots \ldots & \mathbf{1 2 . 5 0} & \mathbf{1 0 0 . 0 0}\end{array}$

\section{lucidum, Glossy Privet}

This is the well-known "Wax-Leaf Ligustrum" with the spreading habit. The plant has thick glossy leaves, attractive blue berries and is a most useful landscape plant. 6 feet.

3- 4' B\&B ....... 27.50 250.00

$30-36$ " B\&B ........ 22.50 200.00

$24-30 "$ B\&B ........ $17.50 \quad 150.00$

18-24" B\&B ........ 12.50100 .00

\section{MAGNOLIA glauca (virginiana), Sweet Bay}

\section{Magnolia}

A most attractive native tree. Its oblong leaves are light green above bright silvery beneath. The tree produces beautiful wax-like pure white flowers which have a delicate odor, followed by cucumber-like ornamental seed-pods. 25 feet.

$$
\begin{aligned}
& \text { 24-30" B\&B ........ } 20.00 \\
& 18-24 " \text { B\&B ........ } 17.50 \quad 150.00
\end{aligned}
$$

\section{grandiflora, Southern Magnolia}

Magnificent specimen tree with big glossy green leaves, and large fragrant white flowers. 40 feet.

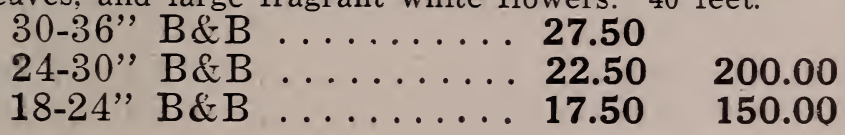


BROADLEAVED EVERGREENS-Continued:

\section{MAHONIA aquifolium, Oregon Holly-Grape}

Shiny bronze-green holly-like leaves. Many leaders are produced from the ground. Attractive yellow spikes of bloom in early Spring are followed by grapelike clusters of blue berries in the Summer. Will tolerate shade. 4 feet.

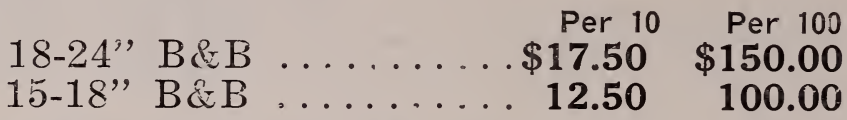

NANDINA domestica, Nandina

A very showy plant whose winter foliage is a bright bronzy-red which forms a beautiful background for large clusters of bright red berries. 5 feet.

$2-3$ ' B\&B ........ $17.50 \quad 150.00$ $18-24 "$ B\&B ........ $12.50 \quad 100.00$

\section{PHOTINIA serrulata, Chinese Photinia}

A beautiful, large shrub graced in early spring by bright red shoots of new growth. The leaves are o inches long, serioted and slichtiy curled. 20 feet.

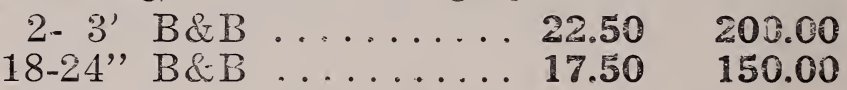

VIBURNUM burkwoodi, Burkwood's Viburnum

The evergreen Viburnum carlesi. Flowers are white and delightfully fragrant, as much as 31/2-4" across. Leaves are small and shiny. Vigorous grower. 6 feet.
$30-36$ ' B\&B ...... 35.00
$24-30 "$ B\&B ....... 30.00
18-24" B\&B ....... 25.00
$15-18 "$ B\&B ........ 20.00

\section{rhytidophyllum, Leatherleaf Viburnum}

Dense compact shrub covered with thick leathery deeply veined leaves. White heads of bloom in Spring are followed by clusters of berries which change from pink through red to black as the season advances. 10 feet.

$$
\begin{array}{lllll}
18-24, & \text { B\&B } & \ldots \ldots \ldots \ldots & 17.50 & 150.00 \\
15-18, & \text { B } \& B & \ldots \ldots \ldots \ldots & 12.50 & 100.00
\end{array}
$$

\section{VINES}

All orders for less than ten of a variety or grade will be invoiced at an advance of $50 \%$ over the ten rate. Any fifty plants (not less than ten of a variety or grade) at the 100 rate.

\section{CELASTRUS scandiens, Bittersweet}

Strong growing vine with dense glossy leaves. Large clusters of orange-scarlet berries. A favorite winter decoration.

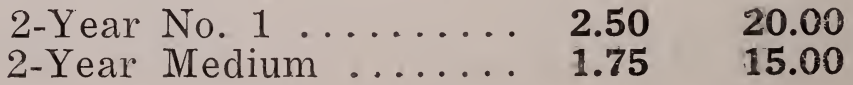




\section{VINES-(Continueđ):}

\section{CLEMATIS, Largeflowering, Assorted}

Colors range from pure white to deep purple. Flowers are usually five or six petalled and up to $4 \frac{1 / 2}{2}$ " across. Summer blooming.

(Shipped direct from contract grower.)

Henryi (Sgle. White)

Jackmanni (Sgle. Purple)

Tangutica obtusiuscula (Golden Clematis, Yellow BellShaped.) (10c additional.)

Texensis (Coccinea. Bright Red, Urn-Shaped.) (10c additional. No. 1 only.)

$$
\begin{aligned}
& \text { 2-Year No. } 1 \ldots \ldots . . . \$ 6.00 \quad \$ 47.50 \\
& \text { 2-Year Medium ....... } 4.00 \quad 35.00
\end{aligned}
$$

\section{paniculata, Sweet Autumn Clematis}

Fragrant white star-shaped flowers in the late Summer. Dense mass of small leaves. Excellent for growing on wire netting or trellis. Thrives best in sun.

(Shipped direct from contract grower.)

$\begin{array}{llll}2-\text { Year No. } 1 \ldots \ldots \ldots \ldots & 4.00 & 35.00 \\ \text { 2-Year Medium } \ldots \ldots \ldots & 3.00 & \mathbf{2 5 . 0 0}\end{array}$

\section{HEDERA helix, English Ivy}

Evergreen Ivy. Excellent covering for stone, concrete or brick structures. Luxuriant, dark green foliage is very glossy. Thrives in dense shade. Good ground cover. Shifted to paper pots for shipment.
21\%" Pots, No. $1 \ldots \ldots . \mathbf{2 . 7 5}$
22.50
21/2" Pots, Medium ..... 2.00
15.00

HYDRANGEA petiolaris-See Schizophragma hydrangeoides.

\section{LONICERA heckrotti, Everblooming Honey- suckle}

This is the beautiful red and yellow gold flame Honeysuckle. The flowers are large, flame-coral in color, lined with gold. The foliage is attractive dark bluegreen. Blooms intermittently throughout the growing season.

2-Year Medium ....... $2.50 \quad 20.00$

japonica halliana, Hall's Japan Honeysuckle Strong, vigorous vine with fragrant white and yellow flowers in late Spring and Summer. Excellent ground cover and bank retainer.

$\begin{array}{llll}2-Y e a r & \text { No. } 1 \ldots \ldots \ldots \ldots & \mathbf{2 . 0 0} & \mathbf{1 7 . 5 0} \\ \text { 2-Year Medium ........ } & \mathbf{1 . 5 0} & \mathbf{1 2 . 5 0}\end{array}$

sempervirens magnifica, Scariet Trumpet Honeysuckle

A strong growing vigorous strain of the old Scarlet Trumpet Honeysuckle. Bright coral-red trumpets are borne in great profusion.

2 -Year No. $1 \ldots \ldots \ldots \ldots . . .600$

2-Year Medium ....... $2.25 \quad 20.00$ 


\section{VINES-Continued:}

\section{LYCIUM chinensis, Chinese Matrimony Vine}

Vigorous grower chiefly valuable as a bank retainer.

Purple flowers in Spring followed by red fruit.

$$
\begin{aligned}
& \text { 2-Year No. } 1 \text {......... \$ } 2.00 \quad \$ 17.50 \\
& \text { 2-Year Medium ....... } 1.50 \quad 12.50
\end{aligned}
$$

POLYGONUM auberti, Silver Lace Vine

Quick rampant grower, presenting a mass of attractive white flower spikes August and September. Dense foliage.

(Shipped direct from contract grower.)

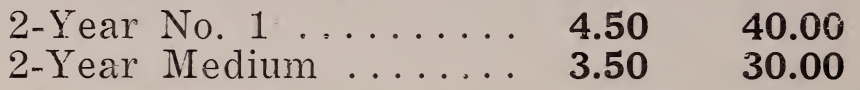

SCHIZOPHRAGMA hydrangeoides, Climbing Hydrangea

A closely clinging vine for masonry walls. Bears a profusion of loose flat clusters of bloom about five inches across. Very ornamental.

$$
\text { 21/2" Pots ........ } 4.00 \quad 35.00
$$

\section{WISTERIA, Grafted Plants}

To be insured of bloom, grafted Wisteria should be used. Many seedling plants are sterile and never produce flowers. The plants offered here are grafted from blooming stock plants.

Pink (Multijuga rosea)

Purple (Sinensis)

White (Sinensis alba)

$\begin{array}{llr}2 \text {-Year No. } 1 . \ldots . \ldots . & 4.00 & 35.00 \\ 2 \text {-Year Medium ....... } & 3.25 & 30.00\end{array}$

\section{sinensis, Chinese Wisteria Seedlings}

The old favorite Wisteria with fragrant spikes of bloom in the early spring.

2-Year No. 1 Seedlings.. $2.50 \quad 20.00$ 2-Year Medium Seedlings $\quad \mathbf{1 . 7 5} \quad \mathbf{1 5 . 0 0}$

MINNESOTA, Dec. 12, 1949: "You have supplied us with excellent stock during the past several years."

TEXAS; Dec. 18, 1949: "We received your shipment last week. shrubs were in fine shape. The usual Chase quality was all included in these good items, and we are proud to have them for กแx Spring collection."

WEST VIRGINIA, Dec. 17 ,1949: "Will place an order with you in a few days for liners. I tell the W. Va. Nurserymen if they want an item in a hurry order from Chase Nursery Company."

OREGON, Dec. 20, 1949: "The stock arrived in good condition, and we are well pleased with the quality."

OKLAHOMA, Dec. 27, 1949: "Enclosed is check for $\$ 131.00$ covering the orcier of Dogwoocis we received from you. We can say that of all the nursery stock we have bought we have never received any finer stock than these plants. Thank you for your prcmpt service." 


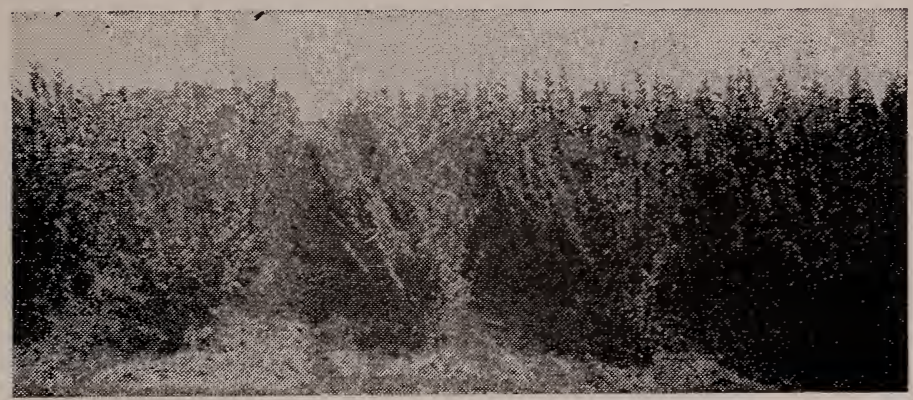

Two Year Privet

\section{HEDGE PLANTS}

\section{LIGUSTRUM amurense, Amoor River Privet (North)}

Vigorous upright grower. Very hardy. Readily adaptable to almost any soil. Dark green leaves, tardily deciduous.

$18-24 " 3$ branches and up $\$ 7.500$ Per 1000 $18-24 " 2$ and 3 branches. $\quad 6.50 \quad 60.00$ 12-18" 3 branches and up $\mathbf{5 . 5 0} \quad \mathbf{5 0 . 0 0}$ 12-18" 2 branches ..... $4.50 \quad \mathbf{4 0 . 0 0}$ $9-12$ " 2 branches .... $3.50 \quad 30.00$

\section{ibolium, Ibolium Privet}

Hybrid of Ibota and Ovalifolium. Carries the former's spreading habit and hardiness, and the latter's evergreen qualities.

2- '3' Well branched . $\quad \mathbf{8 . 5 0} \quad \mathbf{8 0 . 0 0}$ 18-24" Well branched . . $\mathbf{7 . 0 0} \mathbf{6 0 . 0 0}$ 12-18" Well branched . $\mathbf{5 . 0 0} \mathbf{4 5 . 0 0}$

ibota, İbota Privet

Dense spreading habit. Flowers and fruits freely. Very decorative black berries. Very hardy.

$\begin{array}{rrr}\text { 2- 3" Well branched . W } & \mathbf{1 0 . 0 0} & \mathbf{9 0 . 0 0} \\ \text { 18-24", Well branched . } & \mathbf{7 . 5 0} & \mathbf{7 0 . 0 0} \\ \text { 12-18", Well branched .. } & \mathbf{5 . 5 0} & \mathbf{5 0 . 0 0}\end{array}$

\section{ovalifolium, California Privet}

Quick-growing, erect plant with densely clad branches. Foliage is lustrous dark green. The most widely used Privet for hedges, clipped specimens, or massing.

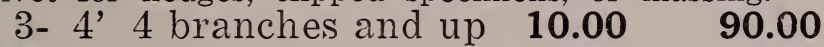

2- 3' 4 branches and up $\quad \mathbf{7 . 5 0} \quad \mathbf{7 0 . 0 0}$ 18-24" 3 branches and up $\mathbf{6 . 0 0} \quad \mathbf{5 0 . 0 0}$ 12-18" 3 branches and up $\mathbf{4 . 5 0} \quad \mathbf{4 0 . 0 0}$

KENTUCKY, Dec. 27, 1949: "Look over this list, if you can possibly do it mail me confirmation; this order to be shipped as early in the Spring of 1950 as possible, by the same trucker you sent before. It's mighty nice to be able to buy from a company like yours, sight unseen, and know you are going to get first ciass stock. I do appreciate it very much." 
HEDGE PLANTS-(Continued):

\section{LIGUSTRUM regelianum, Regal's Privet}

More a shrub than a hedge plant, this low-spreading drooping Privet with its bright leaves and nodding panicles of flowers is valuable for massing or mixed groups. Clipping converts it into a dense attractive hedge. Grown from cuttings.

24-30" Well branched . \$ \$32.50

18-24" Well branched .. $\mathbf{2 2 . 5 0}$

12-18" Well branched .. $\mathbf{1 5 . 0 0}$

\section{sinensis, Chinese Privet (Amoor River}

\section{South )}

The best Southern hedge plant and hardy enough for limited use in protected areas in and around St. Louis and Cincinnati. Completely evergreen in the South. Responds readily to shearing, or develops a beautiful dense screen if left unsheared.

2- 3' Well branched . $\quad \mathbf{8 . 0 0} \$ \mathbf{\$ 7 5 . 0 0}$ 18-24" Well branched . . $\mathbf{6 . 0 0} \quad \mathbf{5 5 . 0 0}$ 12-18" Weli branched . $\mathbf{5 . 0 0} \mathbf{4 0 . 0 0}$

\section{SPIREA vanhouttei, Vanhoutte Spirea}

Makes a beautiful, dense weeping hedge. Covered in Spring by clusters of pure white flowers.

$\begin{array}{llll}18-24 & \text { " Hedging } \ldots \ldots \ldots & \mathbf{6 . 5 0} & \mathbf{6 0 . 0 0} \\ 12-18 \text {, Hedging . . . . . . } & \mathbf{5 . 5 0} & \mathbf{5 0 . 0 0}\end{array}$

\section{ROSES}

\section{CLIMBING ROSES}

\section{(Two Year--Own Root)}

The No. 1 grade carries 24" or more of wood and 3 or more good canes. (Dorothy Perkins, Excelsa, and White Dorothy carry 4 canes and up.)

The Medium grade carries at least 18 inches of wood, and 2 or more good canes.

The No. 2 gracie is graded 12-15" and has at least two canes.

All orders for less than 10 of a variety or grade will be billed at an advance of $50 \%$ over the ten rate regardless of the total number of roses in the entire order.

Per' 10 Per 100

No. $1 \ldots \ldots \ldots . \ldots . \ldots 3.50 \quad \$ 30.00$

Medium $\ldots \ldots \ldots \ldots \ldots 2.50 \quad 20.00$

No. $2 \ldots \ldots \ldots \ldots . . . . . .1 .50 \quad 12.50$

American Pillar (Single red, white-eye)

Cli. Baby Rambler (Red in clusters)

Crimson Rambler (Red in clusters)

Dr. Van Fleet (Beautiful shell-pink.) (5c advance in price)

Dorothy Perkins (Pink in clusters)

-Excelsa (Bright red in clusters)

Exceisa Pillar (Bright red in clusters, Erect grower)

Hiawatha (Single white with red eye)

Silver Moon (Creamy white) ( $5 c$ advance in price)

White Dorothy (White in clusters)

Wichuriana (White ground cover) 


\section{RUGOSA ROSES}

\section{(Own Root)}

The No. 1 grade carries three canes and 18" and up of wood, the medium grade 2 and 3 canes and 15" or more of wood, and the No. 22 canes and 12-15" of wood.

No. $1 \ldots \ldots \ldots \ldots \ldots \ldots \$ \$ \ldots .00 \quad \$ 45.00$

Medium .......... $4.00 \quad 35.00$

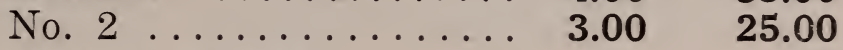

Belle Poitevine (Pink)

Hansa (Red)

Hugonis (Yellow) (Mediums and No. 2's only)

Rugosa alba (Single White)

Rugosa Rubra (Single Red)

Sir Thomas Lipton (White)

\section{BUDDED ROSES}

The No. 1 grade of H. T.'s and H. P.'s carries 18" or more of wood and three or more good canes. The budded Climbers will carry at least 24" of wood and at least three or more canes. The medium grade of $H$. T.'s and H. P.'s carries at least 15-18" of wood and 2 or more good canes. Budded on Multiflora japonica.

No. 1 ..............

Medium

Amelie Gravereaux (Cerise Red Rugosa)

Cli. American Beauty (Dark Red)

Conrad F. Meyer (Pink H. P.)

F. J. Grootendorst (Red Rugosa)

F. K. Druschki (White H. P.)

General Jacqueminot (Crimson H. P.)

M. P. Wilder (Crimson H. P.)

Paul's Scarlet (Vivid scarlet climber)

Prince Camille (Dark red H. P.)

Radiance Pink (Pink H. T.)

Radiance Red (Red H. T.)

Ulrich Brunner (Bright red H. P.)

KENTUCKY, Dec. 28, 1950: "We want to thank you for the prompt service you have given us. We are very much pleased with the stock we have received from your nursery."

VIRGINIA, Dec. 28, 1949: "Shipment received in good condition. Plants were fine and all have been planted. Check enclosed. Thanks."

TENNESSEE, Jan. 3. 1950: "Previously we reported the shortage of one Dogwood on a shipment that we received from you. Later we found this plant in the packing material left in the bottom of the box. Enclosed please find check for amount to cover same. Instead of your boys not being able to count, I am afraid it is a case of my boys being stupid enough not to check thoroughly when they unpacked the order."

NORTH CAROLINA, Jan. 4, 1950: "We enclose check to cover invoice of December 1949. The goods were all of the highest type. We enclose another order we would like to have at the eariliest possible date."

WASHINGTON, Jan. 7, 1950: "Received plants in good shape. Well pleased."

TEXAS, Dec. 24, 1949: "The Tamarix and Abelia received, and we are pleased with it."

ALABAMA, Jan. 14, 1950: "Received the plants yesterday in good condition. Am enclosing check to cover." 


\section{LINING OUT STOCK}

Every item listed is field grown from cuttings or from seedlings transplanted except those marked "S" which means those items are seedlings in beds. Culls are as rigidly excluded from our liners as they are from our finished stock. Refer to the finished stock portions of this Trade List for full descriptions.

Please Make Orders For Lining Out Stock In Multiples of Twenty-five.

\section{DECIDUOUS SHRUBS AND TREES}

Average shipping weight 30 pounds per 100 .

Albizzia julibrissin (Mimosa)

Per 100

2- 3'

18-24"

8.00

12-18"

6.00

8-12"

Berberis thunbergi (Green Barberry) 2-Year 9-12" S 6.00 Berb. thun. atropurpurea 2-Year 9-12" $\mathrm{S} \ldots \ldots \ldots \ldots 10.00$

2-Year 6-8" S ................. 6.00

Buddleia Charming (Pink Butterfly Bush) 8-15" ... 10.00 Buddleia davidi magnifica (Oxeye Butterfly Bush)

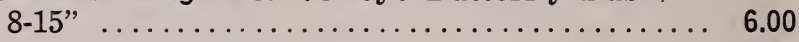

Calycanthus floridus (Sweetshrub) 6-12" S ...... 7.50

Cercis Canadensis (Redbud) 6-12" $\mathrm{S} \ldots \ldots \ldots \ldots . .4 .00$

Cornus fiorida rubra (Pinkflowering Dogwood)

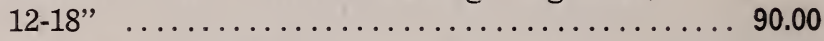

Cydonia japonica (Flowering Quince) 12-15" $\mathrm{S} \ldots . .8 .00$

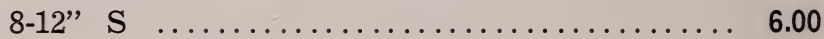

Exochorda grandiflora (Pearlbush) 8-12" S. ...... 7.50

Halesia tetraptera (Great Silverbell) 12-18" S ..... 8.00

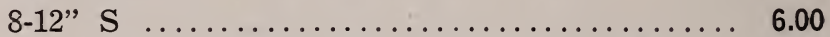

Hisbiscus syriacus (Althea-dble. varieties) $8-15 " \ldots 5.00$

Anemonaefiorus-Pink.

Ardens-Violet

Barner-White, red center

Jeanne d'Arc-White

Lucy-Red

Purpurea semi-plena-Purple

Hisbiscus syriacus (Althea, sgle. varieties) $8-15 " \ldots 8.00$

Coelestis-Blue

Rubis-Red

Snowdrift-White

Hesperalce yuccafolia (Red Yucca) 1-year S. ..... 8.00

Hydrangea A. G. (Snowhill Hydrangea) 6-12" Layers 10.00

Hydrangea P. G. (Peegee) 6-12" Layers ......... 10.00

Ligustrum amurense (Amoor River North Privet) 8-15" 
LINING OUT STOCK-(Continued):

DECIDUOUS SHRUBS AND TREES-Continued:

Per 100

Ligustrum ibota (Ibota Privet) $8-15 " \ldots . . . \ldots \ldots \ldots . \$ 2.50$

Ligustrum sinensis (Anoor River South Privet)

$8-15 "$ S ........................ 1.00

Lonicera fragrantissima (Winter Honeysuckle) 8-15" 6.00

Lonicera morrowi (Morrow's Spreading Honeysuckle) $8-15$ "

Lonicera ruprechtiana (Manchurian Honeysuckle) 3-15"

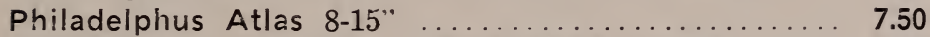

Philadelphus coronarius (Sweet Mock Orange) 8-15" 5.00

Philadelphus grandiflorus (Big Scentless Mock Orange) 8-15"

Prunus glandulosa sinensis (Pinkflowering Almond) 8-12"

(n)

Spirea arguta (Garland S'pirea) 8-12" .......... 6.00

Spirea froebeli (Frcebel's Spirea) 8-15" ......... 9.00

Spirea thunbergi (Thunberg Spirea) 8-12," ........ 6.00

Spirea vanhouttei (VanHoutte Spirea) 8-15" ....... 4.00

Symphcricarpos mollis (Spreading Snowberry) 8-15" 5.00

Symphoricarpos vulgaris (Ccralberry) 8-15" ....... 5.00

Tamarix africana (African T'amarix) $8-15 " \ldots \ldots \ldots .5 .00$

Tamarix amurense (Amur Tamarix) $8-15 " \ldots \ldots \ldots .5 .00$

Ulmus pumila (Chinese Elm)

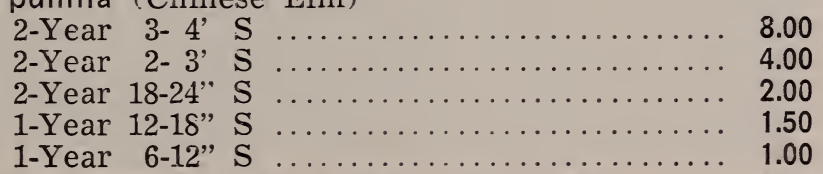

Vitex macrophylla (Lilac Chaste Tree) $8-15$ ".... 7.50

Weigela rosea (Pink Weigela) 8-15" ........... 6.00

Waigela vaniceki (Vanicek's Red Weigela) 8-15" ... 12.50

Please Order in Multiples of Twenty-five

FLORIDA, Jan. 23, 1950: "Enclosing balance for last order. Plants arrived in good condition. Dormant stock now in leaf."

ILLINOIS, Jan. 10, 1950: "We are glad to advise you that we have completed checking the material in the two cars and find that everything checks out satisfactorily."

GEORGIA, Jan. 17, 1950: "The 10 Iimosa shipped me, 5', were excellent. Ship me 10 nore 5 ,."

IVEST VIRGINIA, Feb. 1, 1950: "Not a single casualty yet reported on the lot of 45 Cornus floricla rubra; and only two deaths reported against the lot of 103 you shipped me in the fall of 1948."

WEST VIRGINIA, Feb. 3, 1950: "The material we purchased from you two years ago did very well, and we were much satisfied with it."

OHIO, Feb. 27, 1:50: "The Hetzi Juniper 1 year came and are fine. I wonder if you realize it but your 1 year stock is the size of .most two year old Hetzi. How do you do it?",

ILLINOIS, Feb. 23, 1950: "Enclosed check to cover invoice. Thanks for nice plants."

KANSAS, Feb. 23, 1950: “The stock was nice.. Thanks."

ILLINOIS, Feb. 14, 19j0: "Roses and Nandinas are fine. Thanks."

KENTUCKY, Feb. 16, 1950: "The plants arrived early this morning. We have everything bedded out and planted. I must say it is beautiful stock." 


\section{LINING OUT STOCK-(Continued): \\ CONIFEROUS EVERGREENS}

All of these Conifers are grown from cuttings and transplanted in the fields at least twice except those marked "Pots" meaning that these plants, having been rooted in our hot-beds, are growing under glass in pots of the size specified. The field grown plants are not to be confused with "bed" or "frame-grown" stock. They have grown at least one, and in many instances, two years in our full 42" rows where they have been under a state of high cultivation which has developed character. They will be puddled in mud as dug and the roots carefully packed in Sphagnum Moss in ventilated cases for shipment. Potted stock will be shipped in paper pots of the size specified unless we are instructed to shake out.

NOTE: Pot stock will not be ready for shipment until April of 1951.

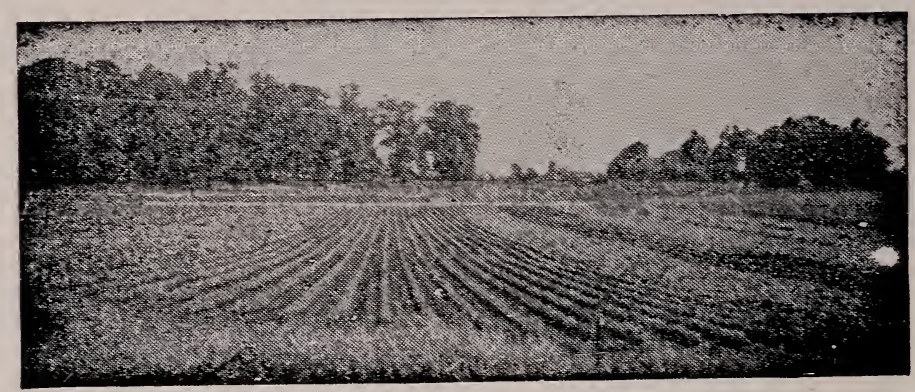

Chase's Famous Evergreen Liners are grown under ideal conditions to produce the best possible root system.

\section{AVERAGE SHIPPING WEIGHT}

Bare Root Stock ....... 30 to 50 Pounds per 100 Potted Stock .............. 25 Pounds per 100

\section{QUANTITIES TO SUIT PURCHASER}

Biota-See Thuja orientalis

Chamaecyparis plumosa (Plume Cypress)

$1-Y r$ 8-12"

1-Yr. $6-8, \ldots \ldots \ldots \ldots \ldots \ldots \ldots \ldots \ldots \ldots \ldots \ldots \ldots \ldots, 25.00$

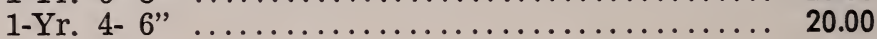

Juniperus chinensis pfitzeriana (Pfitzer Juniper)

2-Yr. 15-18”, ............................ 60.00

2-Yr. $12-15, \ldots \ldots \ldots \ldots \ldots \ldots \ldots \ldots \ldots \ldots \ldots \ldots \ldots \ldots, 50.00$

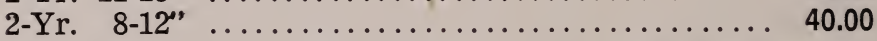

Juniperus chinensis pfitzeriana compacta (Nick's Compact Pfitzer)

$1-Y r .8-12 " \ldots \ldots \ldots \ldots \ldots \ldots \ldots \ldots \ldots \ldots . \ldots, 40.00$

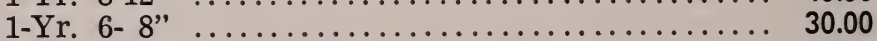

1 -Yr. $4-6, \ldots \ldots \ldots \ldots \ldots \ldots \ldots \ldots \ldots \ldots \ldots \ldots \ldots \ldots \ldots \ldots \ldots \ldots, 20.00$

Juniperus communis ashfordi (Ashford's Juniper)

1-Yr. 8-12" .............................

1-Yr. 6- 8" $\ldots \ldots \ldots \ldots \ldots \ldots \ldots \ldots \ldots \ldots \ldots \ldots \ldots$

1-Yr. 4- 6" 


\section{LINING OUT STOCK-(Continued): \\ CONIFEROUS EVERGREENS-Continued:}

Juniperus communis crocovica (Polish Juniper)

1-Yr. 8-12",

Per 100

1-Yr. 6- 8"

$\$ 25.00$

1-Yr. 4- 6"

Juniperus communis fastigiata (Improved Irish Juniper)

$1-\operatorname{Ir} . \delta-12^{\prime \prime}$

$1-\operatorname{Ir} .6-8$

1-Yr. 4- 6",

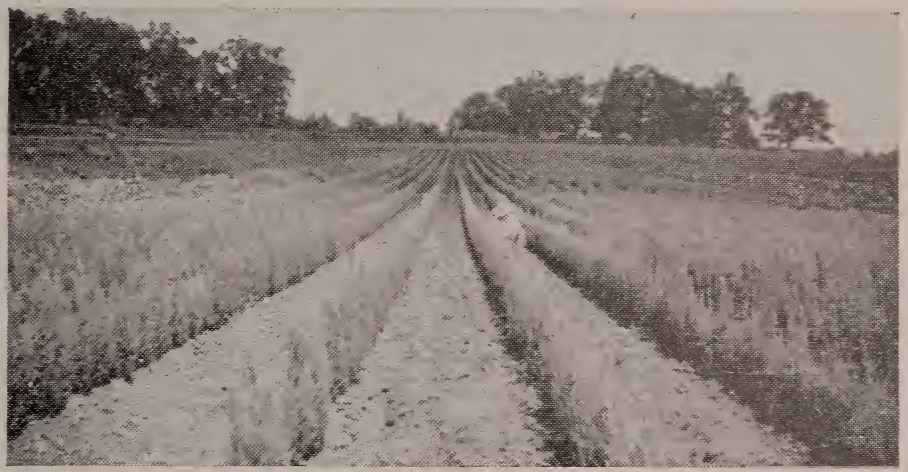

$$
\text { Irish Juniper-"Full of Pep" }
$$

Juniperus communis hibernica (Irish Juniper)

2-Yr. 18-24",

2-Yr. 15-18",

2-Yr. 12-15",

Juniperus excelsa stricta (Spiny Greek Juniper)

2-Yr. 15-18",

2-Yr. 12-15",

2-Yr. 8-12"

1-Yr. 6- 8",

1-Yr. 4- 6",

Juniperus glauca hetzi (Hetz's Blue Spreading Juniper)

2-Yr. 15-18",

2-Yr. 12-15",

40.00

1-Yr. 8-12"

30.00

1-Yr. 6- 8",

25.00

1-Yr. 4- 6",

Juniperus horizontalis (Prostrate Juniper)

2-Yr. 15-18'

2-Yr. 12-15",

2-Yr. 8-12"'

NORTH CAROLINA, Feb. 18, 1950: "My order has been received. Plants are very nice and order has my full approval. Thanks."

KENTUCKY. Feb. 20. 1950: "Our shipment of Abelia axrived and was very nice for which we thank you."

NEBRASKA, Feb. 24. 1950: "We are happy to report that the four boxes of Nursery Stock came through so fast that we could hardly believe it. IIonday we received your letter of the 18th so we notified Watson Bros. office here that we presumea this shipment was going forward Monday and asked them to contact their St. Louis office. We received the shipment this morning about 10 o'clock. 


\section{LINING OUT STOCK-Continued:}

CONIFEROUS EVERGREENS-(Continued):

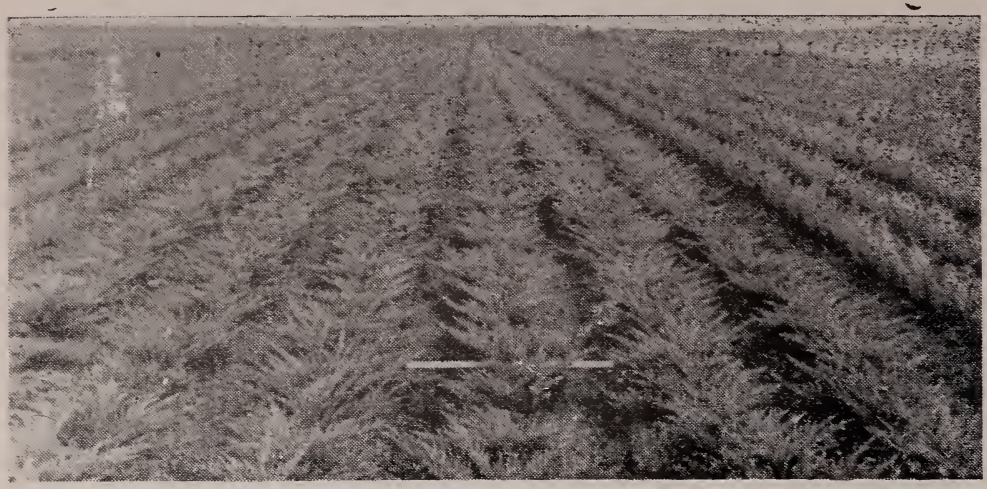

Andorras-Ready to grow into dollars for you. juniperus horizontalis plumosa (Andorra Juniper)

2-Yr. 15-18,

Per 100

2-Yr. 12-15"

$\$ 30.00$

1 -Yr. 8-12",

25.00

$1-$ Yr. 6- 8"

20.00

1-Yr. 4- 6"

15.00

10.00

Juniperus japonica procumbens (Prostrate Japanese Juniper)

2-Yr. 12-15",

2-Yr. 8-12"

50.00

2-Yr. 6- 8",

40.00

30.00

Juniperus sabina (Savin Juniper)

2-Yr. 12-15"

40.00

2-Yr. 8-12"

30.00

2-Yr. 6- 8"

20.00

Thuja orientalis (Biota) aurea (Chase's Golden Arborvitae)

8-12" Field grown

42.50

6- 8" Field grown

32.50

4- 6" Field grown

27.50

2" Pots

22.50

Th. or. conspicua (Goldspire Arborvitae)

8-12" Field grown

42.50

6- 8" Field grown

32.50

4- 6" Field grown ......................... 27.50

2" Pots

22.50

Th. or. aurea nana (Berckman's Golden Arborvitae)

12-15" Field grown ....................... 50.00

$8-12$ " Field grown ........................ 40.00

6- 8" Field grown .......................... 35.00

4- 6" Field grown ....................... 30.00

2" Pots ............................ 22.50

Th. or, aurea nana globosa (Dwarf, Golden Arborvitae)

8-12" Field grown .................... 50.00

6- 8" Field grown ........................ 42.50

4- 6" Field grown .................... 32.50

2" Pots ............................. 22.50

Th. or. bakeri (Baker's Arborvitae)

15-18" Field grown .................... 55.00

12-15" Field grown .................. 45.00

$8-12$ " Field grown ...................... 35.00

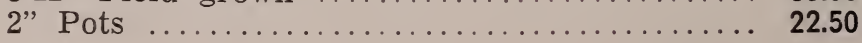


LINING OUT STOCK-(Continued):

CONIFEROUS EVERGREENS-Continued:

Th. or. compacta (Biota Compacta)

8-12" Field grown

6- 8" Field grown

2" Pots

Thuja orientalis elegantissima (Yellow Column Arborvitae)

12-15" Ficld grcwli

8-12" Field grown

2" Pots

Th. or. fruitlandi (Fruitland's Green Arborvitae)

2" Pots

Th. or. giobosa (Chinese Globe Arborvitae)

2" Pots

22.50

\section{BROADLEAVED EVERGREENS}

Field grown except as noted. "POTS" means grown in pots of size indicated. "S" means seedlings from beds. Potted material will be shifted to paper pots for shipment unless we are instructed to shake out. All bare root material will be packed in Sphagnum Moss and ventilated cases for shipment.

\section{AVERAGE SHIPPING WEIGHT}

Bare Root Stock ........... 20 Pounds Per 100

Potted Stock ............. 25 Pounds Per 100

Quantities To Suit Purchaser.

Abelia Edward Goucher (New Pink Abelia)

Per 100

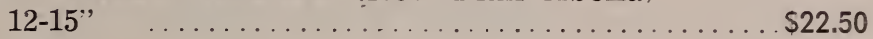

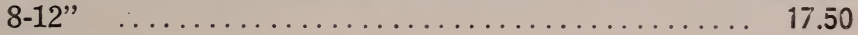

Abelia grandiflora (Gloss:" Arbutus)

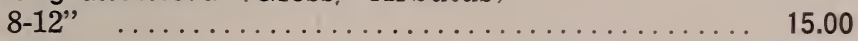

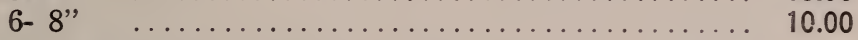

Elaeagnus pungens (Thorny Elaeagnus)

$8-12 "$ S. ............................. 10.00

6- 8" S. ....................... 7.50

Euonymus japonicum variegata (Bright Golden

Variegated Leaf Euonymus Japonica)

21/2" Pots .......................... 20.00

Euonymus radicans carrieri (Glossy Wintercreeper)

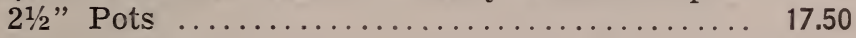

Euonymus radicans colorata (Spreading Wintercreeper)

6-8" ......................... 5.00

I!ex cornuta burfordi (Burford's Chinese Hoily)

$2 \frac{1}{2}$ " Pots

Ilex crenata convexa (Bullata) (Convexleaf Japanese Holiy)

21/2" Pots

llex crenata rotundifolia (Roundleaf Japanese Holly)

$2 \frac{1 / 2}{2}$ "Pots 
LINING OUT STOCK-(Continued):

BROADLEAVED EVERGREENS-Continued:

Laurocerasus caroliniana (Cherry-Laurel)

8-12" S.

6- 8" S.

$\$ 6.00$

4- 6" S.

Ligustrum japonicum (Japanese Privet)

8-12" S.

6- 8" S

4- 6"

Ligustrum lucidum (Spreading Glossy Leaf Privet) 21/2" Pots

Magnolia grandiflora (Southern Magnolia)

$8-12$ " $\mathrm{S}$

6- 8"

$\mathrm{S}$.

Nandina domestica (Nandina)

6- 8" $\mathrm{S}$.

4- 6" S.

Pyracantha coccinea Ialandi (Laland's Firethorn) 2" Pots

Pyracantha crenata serrata (Spreading, Small Bright Red Berries in Heavy Clusters)

2" Pots

Pyracantha crenulata rogersiana (Semi-spreading,

Large Orange Red Berries)

2" Pots

Pyracantha gibbsi (Upright, Red Berries)

2" Pots

Pyracantha yunnanensis (Spreading, Red Berries)

2" Pots .................................

Pyracantha yunnanensis improved (Semi-upright, Large Red Berries)

2" Pots

Viburnum rhytidophyllum (Leatherleaf Viburnum)

$21 / 2 "$ Pots ............................. 40.00

Vinca Minor (Common Periwinkle)

4- 6" Stools

(Vinca available in large quantities. Ask for price)

\section{QUANTITIES TO SUIT PURCHASER}

OKLAHOMA, Marach 2, 1950: "Received all the liners in good condition and was well pleased with them. The Abelia were especially nice."

KANSAS, March 7, 1950: "The shipment arrived in good shape. We like the grade and looks of stock. We have potted the evergreens and they look keen and we just as well gamble some more if you find you have a surplus."

CALIFORNIA, March 8, 1950: "The shipment of Magnolia soulangeana arrived at the nursery on March 1, 1950, in excellent cordition and we are very pleased with these plants and are confident they wiil cio all right. We trust the arrival date is in keeping with what the trucking agent told you. Anyway, the condition of the shipment was perfect. Thank you very much for the attention given our order." 


\section{SUPPLIES}

\section{SPECIAL NOTICE}

All Prices Are Subject To Market Changes

$2 \%$ Sales Tax will be added on Supplies

sold in Alabama.

\section{TERMS ON SUPPLIES}

1. Cash with order or C.O.D.

2. Net Cash 10 Days on known or approved credit rating.

3. NO CASH DISCOUNT ON SUPPLIES and no Packing charges.

Please ADD FOR POSTAGE-guess liberally. Any difference, either way, to be adjusted.

Prices are still uncertain, and are SUBJECT TO CHANGE WITHOUT NOTICE, however, we will do our best for you at all times.

\section{EVERY ITEM TESTED}

We use every item of these Supplies in our own nursery work. Some are made to our specifications.

Each item is numbered for your convenience in making up orders.

\section{KEEN EDGED TOOLS}

\section{Item No. Price}

1. BUDDING KNIFE--Steel Tipped: (Case)

Folding single blade, heavy brass lining. Steel tip to open stocks. Highest quality, fully guaranteed against defective material or workmanship.

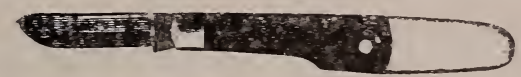

Each, postpaid ...........\$2.75

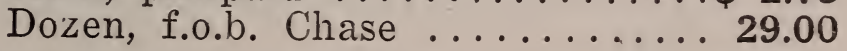

\section{BUDDING KNIFE-Stationary Handle (Schrade)}

Standard size budder, finely finished, and of excellent quality.

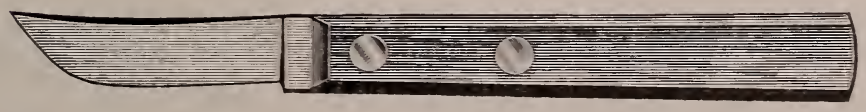

Each, postpaid .......................... 1.05

Dozen, f.o.b. Chase ........... 10.00 (Haif Dozen at Dozen Rate)

\section{Postage Extra-Guess Liberally}

NORTH CAROLINA, Feb. 27, 1950: "Your liners are the best I have seen anywhere, and your shipping can't be beat."

NORTH CAROLINA, March 12, 1950: "The Irish Juniper were fine. Thanks."

OKLAHONIA, March 15, 1950: "Received the Spirea Froebeli in good condition." 
Item No.

KEEN EDGED TOOLS-(Continued)

2-B. BUDDING KNIFE-Stationary Handle (Case)

Single non-folding blade of proper shape and hang. Miade of high grade steel, a good knife. 51/8" overall length.

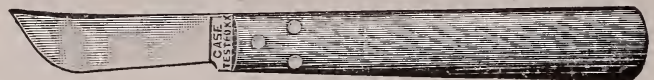

Each, postpaid ...........\$ 1.25

Dozen, f.o.b. Chase .......... 12.00

3. BUDDING \& GRAFTING COMBINA-

TION KNIFE: (Schrade)

Folding double blades, one Budding and one Grafting. White handle $3 \%$ ", nickel-silver bolsters, brass lined, strong and well made. Makes a high class pocket knife.

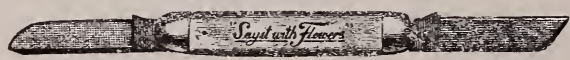

Each, postpaid .......... 2.50 Dozen, f.o.b. Chase .........25.50

5. GRAFTING KNIFE-Stationary Handle: (Schrade)

Standard size grafter, finely finished, and of excellent quality.

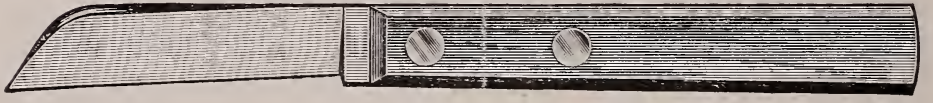

Each, postpaid ............ 1.05 Dozen, f.o.b. Chase ...........10.00

5-A. GRAFTING KNIFE-Stationary Handle (Ulster)

High grade steel set in a strong handle, 61/4" overall length. "Rough and ready" and slightly irregular, but a good knife. Supply limited.

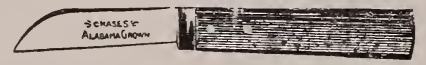

Each, postpaid ............. $\quad .60$

Dozen, f.o.b. Chase ......... $\mathbf{5 . 6 0}$

\section{5-B. GRAFTING KNIFE-Stationary Handle} (Case)

Grafting blade of high quality set in a strong handle, finely finished. Standard size. Best made.

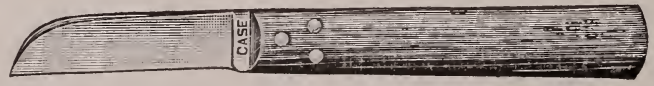

Each, postpaid ............ 1.25

Dozen, f.o.b. Chase ......... 12.00 (Half Dozen at Dozen Rate) 
KEEN EDGED TOOLS-(Continued)

Item No.

6. GRAFTING KNIFE-Jumbo Size:

Price (Case)

Stationary handle grafter for extra heavy work, 3" blade, overall length $73 / 4$ ". Oval walnut handle. Used for field grafting, pecan stocks, etc. A good knife.

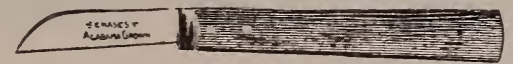

Each, postpaid ............. \$ 2.00

Dozen, f.o.b. Chase ......... 21.75

\section{GRAFTING KNIFE:}

"C.A.G.." folding single grafting blade set in cocoa (sway-back) wood handle, brass lined. As shown. A good knife.

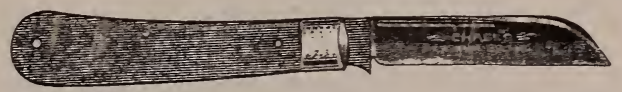

Each, postpaid $\ldots \ldots \ldots \ldots \ldots, 1.95$

Dozen, f.o.b. Chase ......... $\mathbf{1 9 . 2 5}$

\section{7-A. GRAFTING KNIFE-(Case) :}

Case Heavy Grafter. One folding blade, hollow ground. razor edge. A sturdy heavy duty pocket knife.

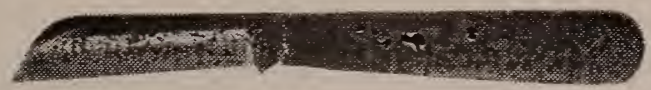

Each, postpaid $\ldots \ldots \ldots \ldots \ldots, 2.40$

Dozen, f.o.b. Chase ......... 24.50

\section{7-B. FLORISTS' KNIFE (Camillus):}

One folding grafting blade, brass lined, white handle with shackle on one end for chain. Made of high grade steel; it makes a clandy pocket knife.

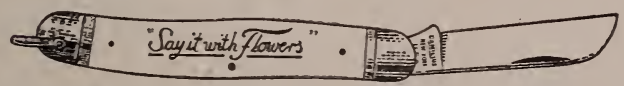

Each, postpaid ........... 1.35 Dozen, f.o.b. Chase .......... 14.00 (Half Dozen at Dozen Rate)

\section{Postage Extra--Guess Liberally}

SOUTH CAROLINA, March 16, 1950: "My last order of Nandinas were delivered in good shape, and they are beautiful plants." CALIFORNIA, March 15, 1950: "Thank you-your selection appreciated and merchandise arrived in grand condition."

MISSOURI, March 21, 1950: "The stock arrived, in good condition. Enclosed is a check for 'cash item.' Thanks."

IOWA, March 21, 1950: "The stock came in fine condition and is very satisfactory."

IOWA, March 22, 1950: "The Spirea Van Houtte hedging checked out entirely satisfactory." 


\section{KEEN EDGED TOOLS-(Continued)}

Item No.

7-C. GRAFTING KNIFE:

Price

One folding blade, brass lined. A many purpose knife, pocket size. Not quite as heavy as Nos. 7 or 7 -A.

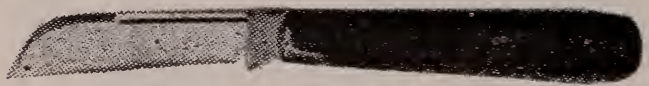

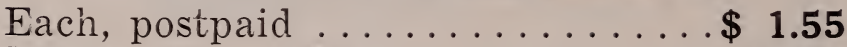

Dozen, f.o.b. Chase ......... 15.50

\section{PRUNING KNIFE-Stationary Handle (Case):}

When suckering it is often necessary to "dig down" below the ground surface. A stiff blade is far better than any folding pruner for this work. This knife meets the situation. Fuli length $73 / 8$ ".

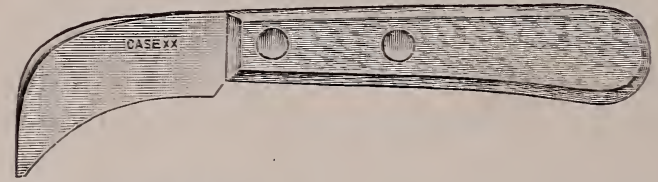

Each, postpaid ......................... 1.45

Dozen, f.o.b. Chase ......... 15.00

\section{8-A. POCKET PRUNER:}

Folding blade $3 \frac{1}{\prime} /$ ", overall length $7 \frac{1}{4}$ ", brass lined. Same size and shape as No. $8-B$, but it does NOT have lock blade.

Each, postpaid .......... 1.20

Dozen, f.o.b. Chase .......... 12.00

(Half Dozen at Dozen Rate)

\section{Postage Extra-Guess Liberally}

ILLINOIS, March 20, 1950: "Shipment arrived this P.M. and the stock is umusualiy nice, bright and snappy and shipment packed right up to the minute, and I would be willing to bet $\$ 50.00$ that the Hibernicas are Irish."

MARYLAND, March 29, 1950: "The 300 plants of Magnolia grandiflora arrived all right and are very satisfactory."

MINNESOTA, March 26, 1950: "Thanks for shipping my order and also for the very fine plants sent me. They are all very satisfactory."

IDAHO, March 25, 1950: "My order was received in fine shape and was very satisfactory. Thank you for the prompt service. Check enclosed for payment in full."

ARKANSAS, March 24, 1950: "Thanks and I am always well pleased with the orciers I receive from you."

GEORGIA, March 26, 1950: "Thanks for prompt handling."

OKLAHOMA, March 29, 1950: "Received the Buddleia in good condition."

WISCONSIN, March 30, 1950: "Those are mighty fine Magnolia and the lining out stock also looked very good. Thanks for the attertion you gave this order."

MICHIGAN, March 31, 1950: "Received the Magnolias in fine shape and want to thank you for making such, a fine package. Just heeled them in and am very well pleased." 
KEEN EDGED TOOLS-(Continued)

Item No.

Price

\section{8-B. FOLDING PRUNER, Lock-Blade: (Camillus)}

One folding blade of standard size, steel lining and bolster, rosewood handle with hole for cord, length closed 4". Lock keeps blade from closing up when in use. A good knife.

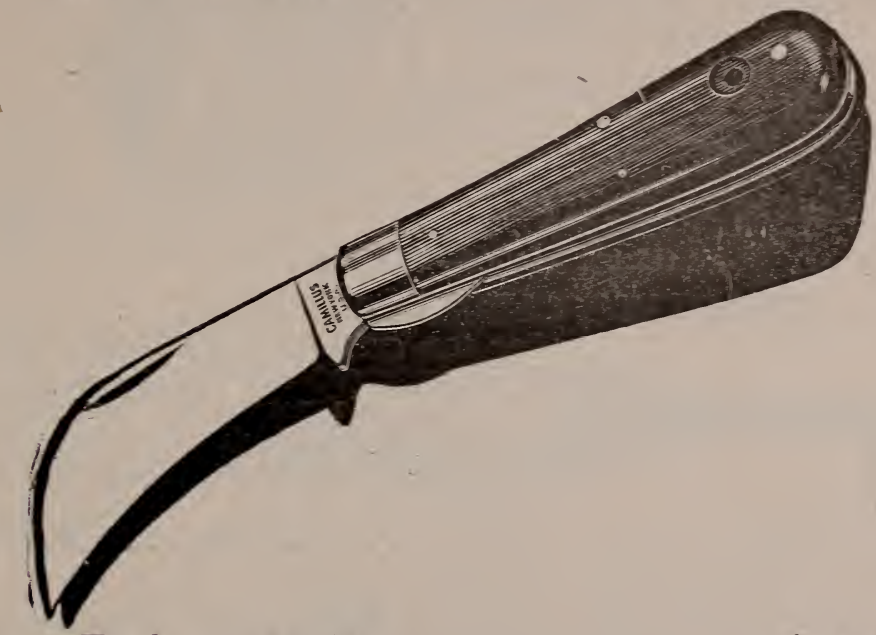

Each, postpaid ...........\$ 1.65

Dozen, f.o.b. Chase .......... 16.50

\section{9-A. DOUBLE-BLADED PECAN BUDDER: (For Ring Budding)}

Two stationary handle knives, set with blades approximately one inch apart. Fastened with special screws and dowel pins. Easily taken apart for sharpening and just as easily reassembled. Preferred by many Pecan budders over all other makes or styles. (Folding blade style is not available.)

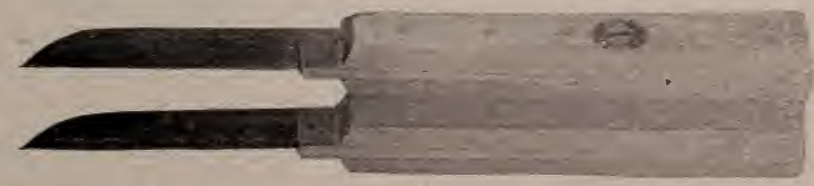

Each, postpaid ........... 2.50 (Half Dozen at Dozen Rate)

\section{Postage Extra-Guess Liberally}

ILLINOIS, March 31, 1250: "The stock arrived here yesterday. It came as always, fine and dandy, well pleased."

KENTUCKY, April 3, 1950: "All the shipments reached us in first class condition. The roots wero packed nicely to keep them from drying out and of course all plants were up to our expectations in regard to size and quality. We won't say it exceeded our expectations as we have come to expect the best when we order from Chase, and as yet have not been disappointed." 


\section{KEEN EDGED TOOLS-(Continued)}

Item No.

\section{PATCH-BUDDING KNIFE:}

Price

The Jones Patch Budder, cuts a bud much as a biscuit cutter operates. Handle of aluminum, blades $1 / 2 \times 1$ " of razor steel.

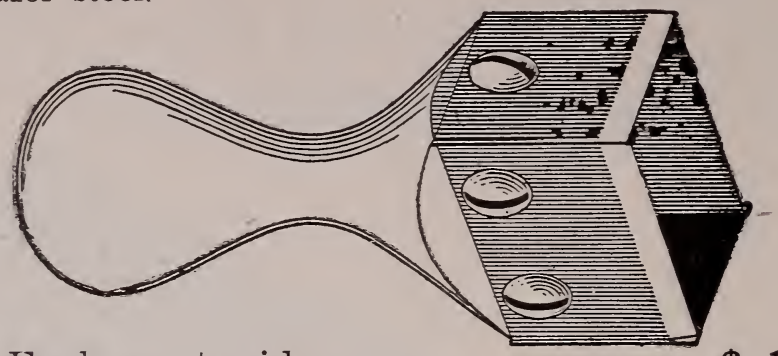

Each, postpaid ............\$ 1.75 (Extra blades-Per set 50c)

\section{GRAFTING CHISEL: (Tiffany)}

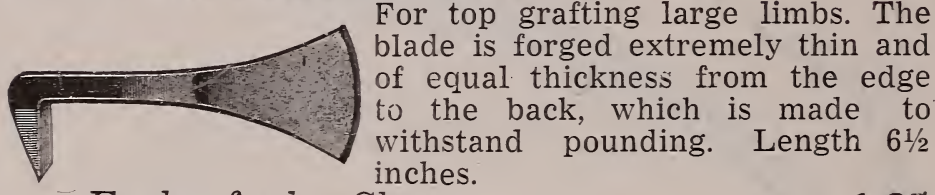

Each, f.o.b. Chase .......... 1.25

\section{GRAFTING TAPE:}

An adhesive tape prepared for wrapping grafts and buds, and used in connection with Items 9 and 11 .

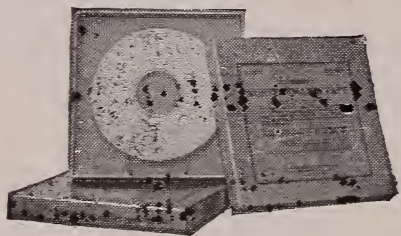

Forms a stick-fast, air-tight waterproof seal. Adds great strength at union. Fine for wrapping top-worked pecan buds and grafts. Half inch wide, 60 yards to the roll.

1 to 24 Rolls, each, f.o.b. Chase... $\quad .75$ 25 to 91 Rolls, each f.o.b. Chase .. $\quad .70$

92 Rolls (case lots) each f.o.b. Chase $\mathbf{. 6 7}$ NOTE: For Grafting Thread and Grafting Wax, See Items 59-60.

\section{WHETSTONE (Carborundum):}

Pocket size. Should be in the pocket of every budder and grafter. Makes a good knife hoìd a good edge if properly used-spit on it and finish on side of your shoe.

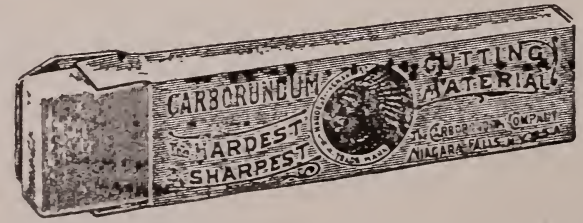

Each, postpaid ........... $\quad 40$ Dozen, f.o.b. Chase ........... 3.75 (Half Dozen at Dozen Rate) 
KEEN EDGED TOOLS-(Continued)

Item No.

Price

14. FRENCH PRUNING SHEARS:

We are still unable to get positive commitments in France, but there is hope. If interested, tell us how many you could use during the next year.

\section{FRENCH SHEAR REPAIRS:}

"Let Jack Do It"

We still have some parts for all sizes French Shears and if you have some used French Shears that need adjusting - new blades, bolts, springs, or frames - send them in and our Jack Smith will put them in shape (if any one can) and at reasonable cost. "LET JACK DO IT."

\section{SHEAR SPRINGS:}

Volute (Spiral) type for all sizes.

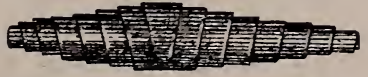

Each, postpand $\ldots \ldots \ldots \ldots \ldots \ldots \$ .15$

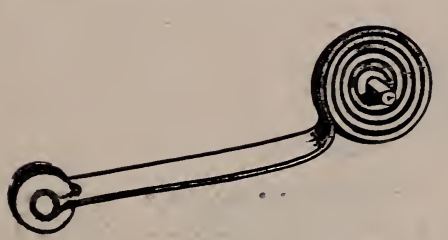

16. SPRING FOR FRENCH SHEARS:

Roller (Old Style) type for all sizes. Be sure and state size wanted.

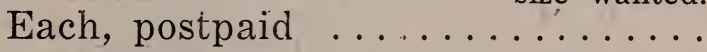

\section{AMERICAN "CLIPPER" PRUNER:}

A low priced, easy cutting, heavy duty, yet light weight pruner. American made. It is all steel-no castings. Blade and hook are hardened and tempered. Has comfortable, non-pinching grip. One-hand safety catch can be operated with thumb of hand holding the pruner. Length overall 8 inches, weight 10 ounces. Try it once and you'll say it is the finest, low-priced pruner on the market.

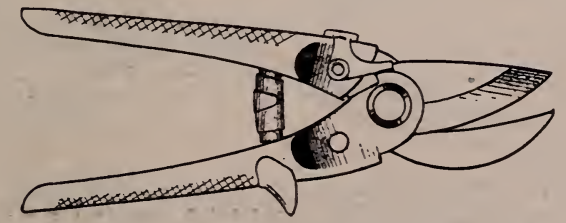

Per Pair, f.o.b. Chase ........ 1.40

Per Dozen, f.o.b. Chase ....... 14.50 


\section{KEEN EDGED TOOLS-(Continued)}

Item No.

Price

\section{8. "SNAP-CUT" PRUNER-Aluminum:}

New iight-weight, streamlined "Snap-Cut" aluminum alloy body. A new modern sturdy pruner unsurpassed for pruning comfort. It is an effortless performer, cutting branches $3 / 4$ " thick like matchwood. Non-tiring to hands and no burden in the pocket. Blade of finest alloy steel. New anvil construction means closer, more positive cut with less bark injury. One hand safety catch, built in, snag proof and durable. ALL PRUNER PARTS EASILY REPLACABLE.

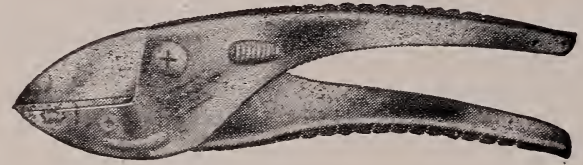

Each, f.o.b. Chase $\ldots \ldots \ldots \ldots \ldots 2.50$

Dozen, f.o.b. Chase .........25.00 18-C. "PROFESSIONAL" PRUNER-8 Inch:

Finest one-piece drop forged steel. Adjustable nut lock and bolt support. Non-pinching shaped handles with leather catch. A pruner for the most experienced horticulturist.

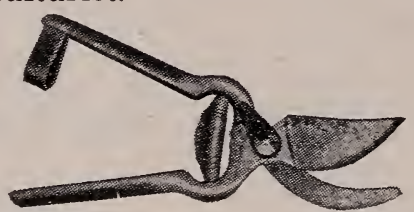

Each, f.o.b. Chase .......... 3.25

Dozen, f.o.b. Chase ........ 32.00 (Half Dozen at Dozen Rate)

\section{9-A. HEDGE SHEARS-“CORONA"}

Made of fine high carbon steel, blades heat treated to hold their edge. Serrated blade edge prevents slipping when cutting. Easy grip hardwood handles, reinforced with steel throughout, cannot come off. Excellent balance, easy to operate, 8" blades. A high class tool. UNCONDITIONALLY GUARANTEED FOR 12 MONTHS.

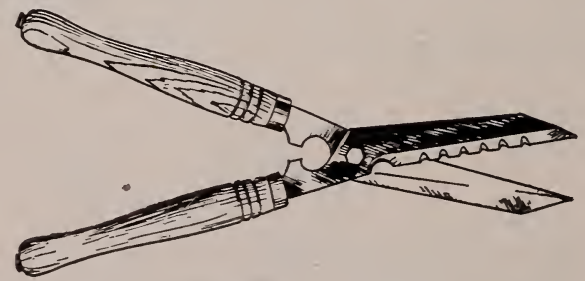

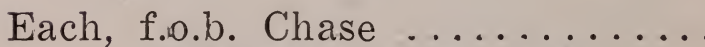

(Half Dozen at Dozen Rate)

\section{Postage Extra-Guess Liberally}

MARYLAND, April 3, 1950: "MIagnolia Soulangeana recently ordered were received in excellent condition. Thank you.'

WEST VIRGINIA, April 4, 1950: "I received your order No. No. 4100 and they were in perfect shape. You sure have made a new customer and friend." 


\section{KEEN EDGED TOOLS-(Continued)}

Item No.

19-B. HEDGE SHEARS- "NEWMAN"

Price

Heavy duty hedge shears. Blades 81/2" long made from finest quality hedge shear steel. Lower blade notched for cutting larger limbs. Handles attached by means of hydraulic pressure and are permanent. Weight $2 \frac{1 / 4}{4} \mathrm{lbs}$.

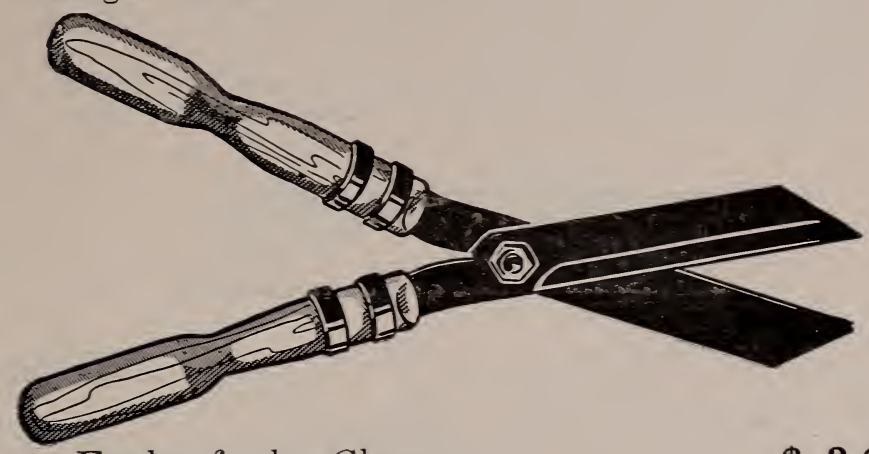

Each, f.o.b. Chase .........\$2.60

\section{0. “LOPPING” SHEARS:}

Two hand, extra heavy, single cut. For "dehorning" in orchard, and general heavy pruning. Length overall 26 inches, the long handle gives leverage. Weight $33 / 4$ lbs.

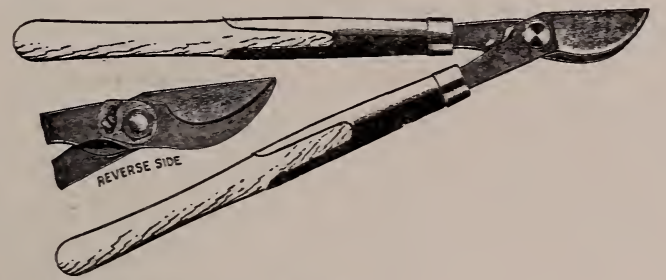

Per Pair, f.o.b. Chase ........ 4.00

\section{3-A. TREE TRIMMER-Heavy Duty:}

This trimmer employs a wholly new principle in that it cuts from the top down rather than the bottom upwith the law of gravity, rather than against it. It features compound leverage, plus ball bearing pulleys. Makes a full 11/2" cut. Handles 11/2" in diameter, furnished complete with two 5 -foot sections, $10 \mathrm{ft}$. overall. Weight $6 \frac{1 / 2}{2}$ lbs. Additional center sections can be secured, length 5;, weight 2 lbs., shipped direct from factory.

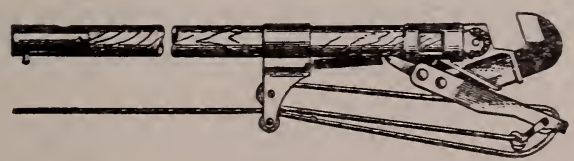

Each, f.o.b. Chase ......... 15.00 
KEEN EDGED TOOLS-Continued:

Item No.

\section{3-B. TREE TRINIMER-Featherweight:}

This featherweight trimmer is designed for lighter work than the No. 23-A above. It is especially adapted for topping or work in the tree. Makes a 1" cut. Single puiley action, all pulleys are ball bearing for easier operation. Furnished complete with two 5-foot sections, 10 -ft. overall. Handles are $1 \frac{1 / 4}{}$ " in diameter, net weight $43 ; 4$ lbs.

Additional center sections can be secured, length 5', weight $1 \%$ lbs., shipped direct from factory.

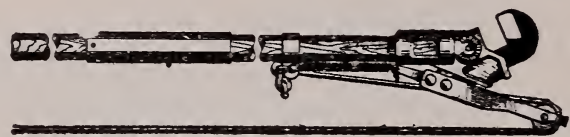

Each, f.o.b. Chase $\ldots \ldots \ldots \ldots \ldots 10.50$

\section{PRUNING SAW (Disston):}

Fast, keen cutting, will handle large limbs or small branches. Draw cut on a slight curve-easy on operator. Made of high grade steel.

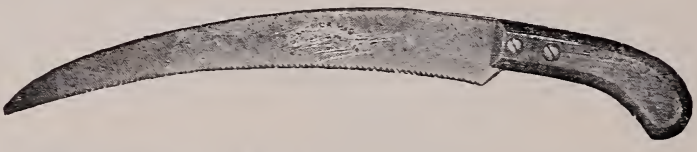

Each, f.o.b. Chase .......... 1.85 Dozen, f.o.b. Chase ......... 18.00

\section{PRUNING SAW (Atkins):}

Curved pruner, made of genuine SILVER STEEL. Has a very narrow blade with rip teeth. Handle of air dried beech handsomely lacquered, fastened to the blacle with two nickled screws. Popular with citrus fruit growers. (Use 7" slim taper file.)

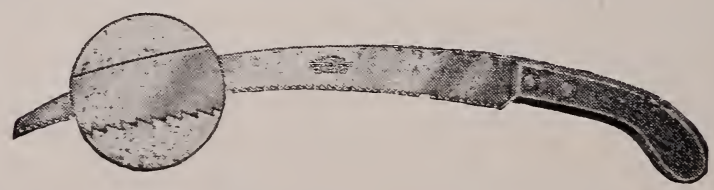

Each, f.o.b. Chase .......... 2.45

Dozen, f.o.b. Chase .........25.00 (Half Dozen at Dozen Rate)

\section{Postage Extra-Guess Liberally}

MICHIGAN, April 5, 1950: "muanks for sending us such good stock, which is the usual thing from you."

ILLINOIS, April 7, 1950: "Enclosed find check to cover invoice, plus the discount. We believe the stock passed any others. it sure was fine, it always is though or you folks make it right. That's why it is such a pleasure to do business with you."

ILLINNOIS, April 7, 1950: "Enclosed find check in payment for stock which is really fine."

INDIANA, April 11, 1950: "Thanks for your prompt service."

UTAH, April 11, 1950: "The stock arrived in fine condition. Many thanks." 


\section{HAND CULTIVATING AND DIGGING TOOLS}

(DIBBLES, FORKS, WEEDERS, SPADES, AND TROWELS)

Item No.

26. DIBBLE (Aluminum) :

Price

For "dibbling in" (planting) young pips, seedlings, etc. A very useful tool. Now made with pistol grip; overall length 11 inches, point is 5 inches long, tapered from 11/4" diameter. Made of highly polished aluminum. Rust proof. Weight 6 ounces.

Each, f.o.b. Chase .........\$ 1.45

Dozen, f.o.b. Chase ......... 14.50

\section{FORK, English Model:}

If you have never used this English style spadingdigging fork, you should do so. Has square tines instead of old style man-killing flat tines; is far easier on the operator. Costs a little more, worth a lot more. Fork, shank and strap in one piece of steel.

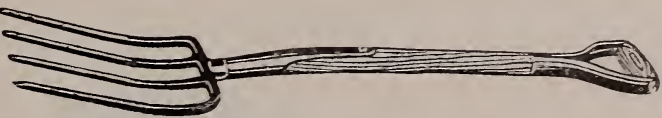

Each, f.o.b. Chase .......... 3.15

\section{MAGIC WEEDER:}

A handy tool for use in seed beds and greenhouse benches. Has three spring tines made of best quality steel obtainable for the purpose. Length overall 18".

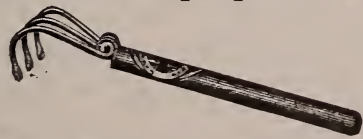

Each, f.o.b. Chase .......... .35

Dozen, f.o.b. Chase .......... 2.70

\section{9-C. LEONARD'S NURSERY SPADE:}

A heavy spade with double straps full length; five rivets; "Y" type reinforced metai handle with wood. grip. Weight 7 pounds. Tapered blade 13" long.

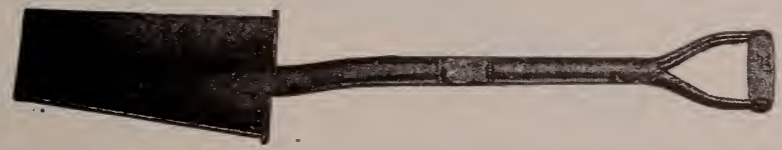

Each, f.o.b. Chase .......... 6.50 Dozen, f.o.b. Chase .......... 72.00 (Half Dozen at Dozen Rate) 
HAND CULTIVATING AND DIGGING TOOLS (Continued):

Item No.

Price

30. SPADE HANDLE:

These are extra handles for Nursery Spades, bent to fit and riveted. Can be put in place by any good blacksmith.

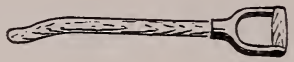

Each, f.o.b. Chase .........\$ 1.25

\section{ALUMINUM GARDEN TOOLS,} Markle "Featherlite"

Guaranteed for life. Nade of solid one piece die cast aluminum alloy. Non-rusting and easy to clean, self sharpening. Has a patented finger rest for comfort. and untiring use. Makes an excellent gift for your gardening friends.

GUARANTEED FOR LIFE-Any Markle Tool damaged in ordinary garden usage will be replaced FREE OF CHARGE. Simply return it to us.

\section{2-A. GARDEN TROWEL:}

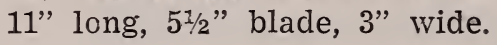

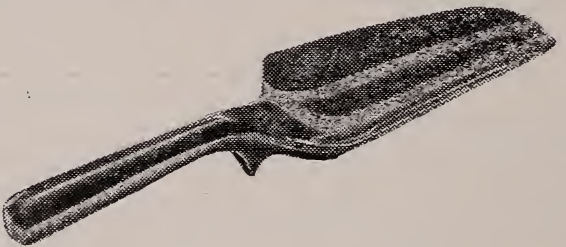

Each, f.o.b. Chase .......... $\mathbf{. 7 0}$

Dozen, f.o.b. Chase ......... 6.25

32-B. TRANSPLANTING AND BULB TROWEL:

103/8" long, 41/2" blade, 11/2" wide.

Each, f.o.b. Chase .......... .60

Dozen, f.o.b. Chase ......... $\mathbf{5 . 5 0}$

(Half Dozen at Dozen Rate) 
HAND CULTIVATING AND DIGGING TOOLS (Continued):

Item No.

32-C. CULTIVATING FORK:

Price

$95 / 8$ " long, 41/2" prongs, 3" wide.

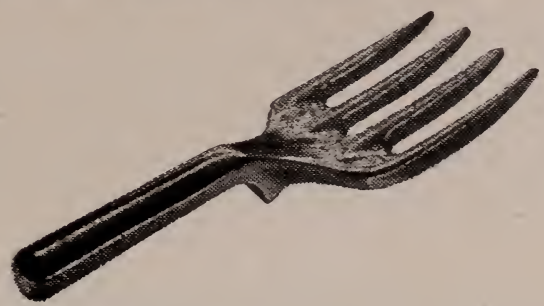

Each, f.o.b. Chase ..........\$.70

Dozen, f.o.b. Chase ......... 6.25

\section{2-D. "FEATHERLITE" GARDEN SET:}

Containing one Garden Trowel, one Transplanting and Bulb Trowel, and one Cultivating Fork as shown above.

Per Set, f.o.b. Chase ......... 1.90

\section{(Half Dozen at Dozen Rate)}

(May be assorted.)

\section{Postage Extra-Guess Liberally}

ILLINOIS, April 11, 1950: "Stock looks fine."

UTAH, April 10, 1950: "The shrubs arrived in good condition. I am well pleased with them."

NEW YORK, April 15, 1950: "Shipment of Evergreens received. I think they are the best transplants I have ever seen."

ILLINOIS, April 15, 1950: "We received the shipment of shrubbery and it was very nice."

WEST VIRGINIA, April 17, 1950: "I certainly appreciate your making up the Spiny Greek loss. These last plants look fine and I expect good results from them."

ALABAMA, April 18, 1950: "Thanks for your prompt attention to the order."

MISSOURI, April 17, 1950: "Plants were nice and we will order earlier next year."

PENNSYLVANIA, April 17, 1950: "I got my lining out stock, it came in fine, very nice. I hope we do business every year from now on."

KANSAS, April 17, 1950: "The liners were fine, came through in fine shape and we will need some more for next year."

MICHIGAN, April 19, 1950: "We were very well pleased with the stock that we received. I just wish I had ordered another 150 Pfitzer Junipers, 8-12" from you." dition."

ILLINOIS, April 21, 1950: "Nice stock received in good con-

TENNESSEE, April 25, 1950: "Received my lining-out evergreens they were nice and in good condition."

PENNSYLVANIA, Apri1 25, 1950: "The plants are very nice and arrived in good condition.", 


\section{GRADING, PACKING AND SHIPPING SUPPLIES}

(Box Straps, Burlap, Cordage, Labels, Moss, Gloves, Needles, Paper, Tacker, Tree Counter and Tree Gauge) All Items in This Group, Unless Otherwise. Noted, Are Priced f.o.b. Chase.

Please tell us how to ship, by freight or express

SHINGLE TOW - write us if interested. We have contact with several truckers and can probably arrange truck load delivery at a reasonable cost. This is a service to our customers-a non-profit item.

Item No.

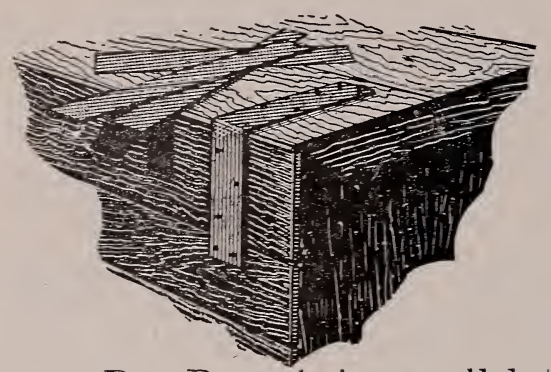

33. BOX STRAPS:

Cut from soft steel, once used, 40 inch Strong e $\mathrm{n} \mathrm{o} \mathrm{u} \mathrm{g} \mathrm{h}$ to hold the heaviest box, but light enough to nail through without punching. About 2,300 pieces in 100 pounds.

Per Pound, in small lots ......\$ .121/2 Per Pound, in 50-1b. package ... . .111/2

34. BURLAP 100 Yard Bolts: High grade burlap, once used, 40 inch $71 / 2$ oz. stock, neat, and clean, sewn into lengths of $33 \quad 1-3$ yards, three of these pieces tied into one bolt containing 100 yards. In stock for quick shipment.

Per Yard (Bolt of 100 yards) .... . $\mathbf{. 1 1 1 / 2}$

Per Yard (500 yards or more) .. .111/4 (Cannot break bolts)

\section{4-A. BURLAP SHEETS:}

Size $36 \times 40$ " and up, good grade used burlap. Put up in wire bound bales containing 250 sheets.

Per Bale, (250 sheets) f.o.b. South Georgia ......... 19.00 (Cannot break bales.)

35-A. BINDER TWINE:

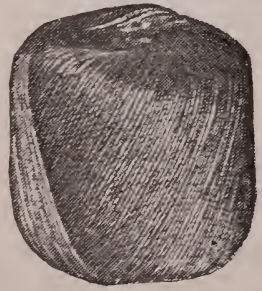

Good grade Yucatan Binder Twine. Put up in bales of ten 5-Pound balls. Five hundred feet to pound. Most economical.

Bale, (about 50 lbs.) $\mathbf{1 3 . 2 5}$ Ball, (5 lbs.) ..... $\mathbf{1 . 5 0}$ 
GRADING, PACKING AND SHIPPING SUPPLIES

(Continued):

Item No.

\section{5-B. BINDER TWINE HOLDER:}

Price

If you use binder twine for bunching and balling as we do, no doubt you have had it to snari and the loss is heavy. The picture is self explanatory. Inside dimensions are $7 \frac{1}{2}$ " in diameter and $7 \frac{1}{2}$ " " deep, with an inch wide reinforced hinged handle perforated so that the twine runs freely from the center of the ball. This will carry either a 5-1b. or 8-lb. ball. Made of heavy galvanized iron.

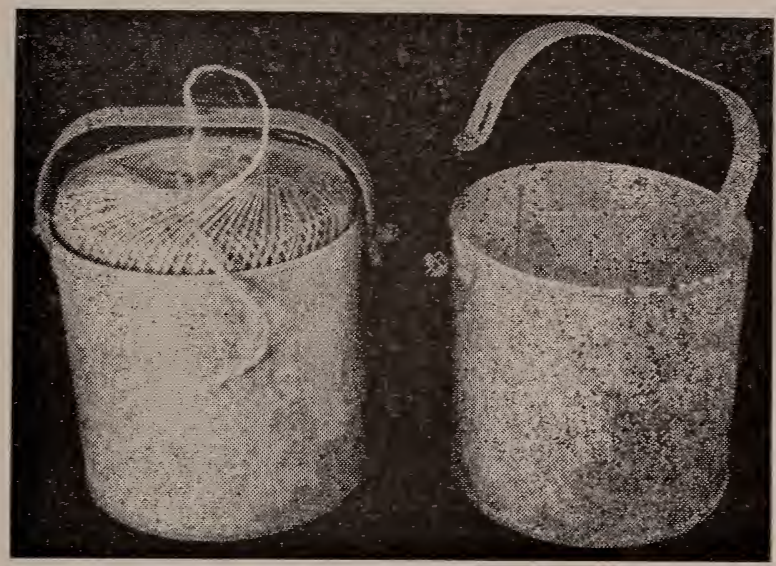

Each, f.o.b. Chase .........\$2.55

\section{NAILS-BALLING or PINNING:}

Genuine nursery nail, smooth, bright, needle point, flat head. Will average approximately 432 to the pound. Ideal for pinning burlap on a B\&B plant instead of sewing. Sample on request.

Per Pound, f.o.b. Chase ........ $\quad .20$

Per Keg (100 lbs.) f.o.b. Chase .... 15.65 (Limit one keg to a customer while they last-sorry.)

\section{CORDAGE-EXPRESS CORD:}

Two-ply medium, in reels weighing about 50 pounds, in single ends.

Specify which is wanted.

MEXICAN SISAL_Good Quality

Per Pound, f.o.b. Chase ........ . 30

PLYMOUTH SISAL_-Best Quality

Per Pound, f.o.b. Chase ........ . .37

(Cannot break reels.) 
GRADING, PACKING AND SHIPPING SUPPLIES (Continued):

Item No.

\section{CORDAGE-COTTON SAIL TWINE:}

For sewing burlapped bales or balls. In skeins only, cut in 10-foot lengths, many ends.

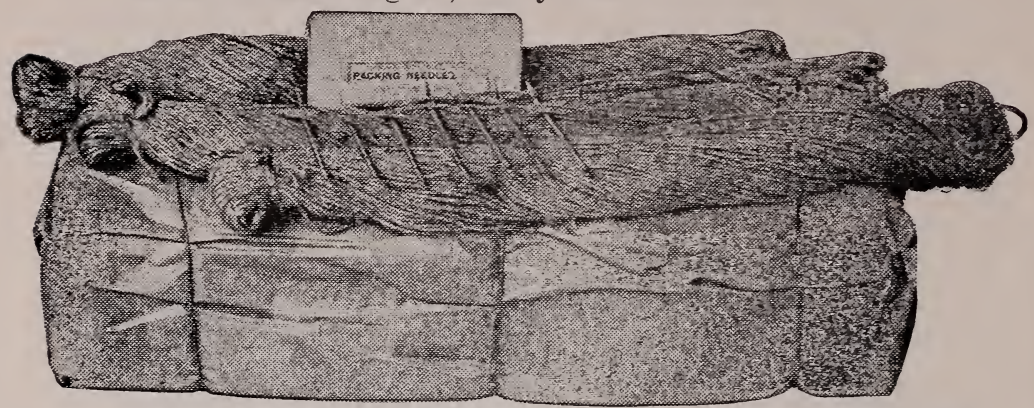

Per pound, in skems .........\$.85 (Cut in 10-foot lengths)

\section{LABELS - WOOD TREE LABELS}

NOTE: Postage On Labels Averages About 30 c per 1000.

If wanted by parcel post, please $\mathrm{ADD}$ to your remittance, any difference to be adjusted.

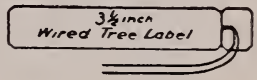

39. LABELS-Plain Iron Wired:

$3 \frac{1}{2}$-inch Plain (not painted), 1,000 to package.

Per Thousand ............. $\mathbf{3 . 0 0}$

Per Thousand, in 10,000 lots . . . 2.80

40. LABELS-Plain Copper Wired:

Plain (not painted), 31/2-inch, 1,000 to package.

Per Thousand ................

Per Thousand, in 10,000 lots .....

41. LABELS-Painted Copper Wired:

A coat of white paint gives better writing surface and lasts longer, $3 \frac{1 / 2}{2}$-inch, 1,000 to a package.

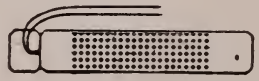

Per Thousand ............. $\mathbf{3 . 8 0}$

Per 'Thousand, in 10,000 lots .... $\mathbf{3 . 6 0}$ 
GRADING, PACKING AND SHIPPING SUPPLIES

(Continued):

Item No.

Price

42. LABEL PENCIL:

Large indelible weatherproof lead of right texture for writing on wood labels.

Each, postpaid ..........\$.10

Dozen, f.o.b. Chase ......... 1.00

43. LABEL WIRE-Copper:

Copper Label Wire, cut approximately 7 inches long, best quality, in bundles weighing about $1 \frac{1 / 4}{1 b s}$. We cannot break bundles.

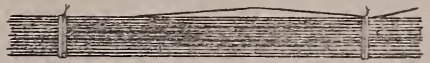

Per Pound, f.o.b. Chase ....... . .74

44. LABELS--Plain 4-Inch Florists' Pot:

4-inch. Pointed wooden label, unpainted. Size $4 x 5 \%$ ", packed 1,000 to box. Used by florists in small pots and to slip under strings on bunches of strawberry plants.

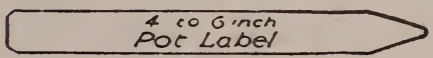

Per Thousand, f.o.b. Chase ...... 2.50

45. LABELS-Painted 4-Inch Florists' Pot: 4-inch. Same as above, except painted white.

Per Thousand, f.o.b. Chase ..... 3.00

46. LABELS-Plain 6-Inch Florists' Pot:

6-inch. A pointed wooden label, unpainted. Size $6 \times 7 \% "$, packed 1,000 to box. Largely used in cold frames and greenhouses.

Per Thousand, f.o.b. Chase ...... 3.05

47. LABELS--Painted 6-Inch Florists' Pot:

6-inch. Same as preceding, except painted white.

Per Thousand, f.o.b. Chase ..... 3.65

48. LABELS-Plain 8-Inch Garden:

8-inch. A pointed wooden label, unpainted. Size $8 x^{7} / 8 "$, packed 250 to box.

\section{8 inch}

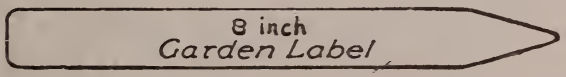

Per Box of 250, f.o.b. Chase..... \$ 1.90 Per 1,000, (4 boxes) f.o.b. Chase .. 6.90

49. LABELS-Painted 8-Inch Garden:

8-inch. Same as above, except painted white.

Per Box of 250 , f.o.b. Chase ..... 2.15

Per 1,000 (4 boxes) f.o.b. Chase . 7.90 
GRADING, PACKING AND SHIPPING SUPPLIES

(Continued):

\section{LABELS-PAPER}

Item No.

50-A. LABELS--Paper, Shank Type

(Style "A") :

Price

Shank is 1 inch wide, now has two slits; writing or printing surface 1/2" wide; 61/8" long. Strong, waterproof to a considerable degree. 10 to sheet, 1,000 to package. (Cannot break package.)

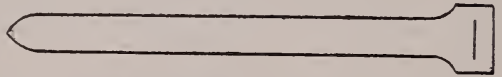

Prices, Plain (Blank) :

1,000 to 4,000 , Per 1,000, f.o.b. Chase $\$ \mathbf{. 9 5}$ 5,000 to 9,000 , Per 1,000, f.o.b. Chase .88 10,000 up, Per 1,000, f.o.b. Chase .... $\mathbf{8 3}$

Prices, PRINTED, One Line, One Side:

2,000 to 4,000, Per 1,000, f.o.b. Chase $\mathbf{1 . 7 4}$ 5,000 to 9,000 , Per 1,000, f.o.b. Chase $\mathbf{1 . 4 9}$ 10,000 up, Per 1,000, f.o.b. Chase ... 1.34

Cannot print less than 2,000 total. ADD 10c per name when under 1,000.; Add 10c per 1,000 for two lines. Cannot print less than 100 of a name. Ask for prices on large lots.

\section{0-AX. LABELS-Paper, Shank Type-}

\section{COLORED. (Style "A"):}

Same size and style as No. 50-A ayove. These COLORED labels are ideal to use in labeling different type of shrubs, roses, etc.-use a distinct color for each kind or grade of plant. Colors available: Green, Gray, Blue, Orange, Red and Yellow. STATE COLOR WANTED. (Cannot break package.)

Prices, Plain (Blank) :

1,000 to 4,000 , Per 1,000 , f.o.b. Chase $\mathbf{1 . 2 5}$ 5,000 to 9,000, Per 1,000, f.o.b. Chase $\mathbf{1 . 1 5}$ 10,000 up, Per 1,000, f.o.b. Chase .... 1.10

Prices, PRINTED, One Line, One Side:

2,000 to 4,000 , Per 1,000, f.o.b. Chase 2.04 5,000 to 9,000 , Per 1,000 ,f.o.b. Chase $\mathbf{1 . 7 6}$ 10,000 and up, Per 1,000, f.o.b. Chase $\mathbf{1 . 6 1}$

Cannot print less than 2,000 total. ADD 10c per name when under 1,000. ADD 10c per 1,000 for two lines. Cannot print less than 100 of a name. Ask for prices on large lots. 
GRADING, PACKING AND SHIPPING SUPPLIES

(Continued):

Item No.

50-B. LABELS-Paper, Strap Type,

Price (Style "B"):

Slit in horizontal position, 10 to sheet, 1,000 to package. (Cannot break package.)

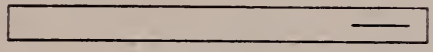

Prices, Plain (Blank):

REGULAR JUMBO $6 " \times 1 / 2 "$ " $" \times 5 / 8 "$ Per 1,000 Per 1,000

1,000 to 4,000 , f.o.b. Chase . $\$ \mathbf{\$ . 8 0} \quad \mathbf{\$ 1 . 2 5}$ 5,000 to 9,000 , f.o.b. Chase $\ldots \quad \mathbf{. 7 3} \quad \mathbf{1 . 1 5}$ 10,000 and up, f.o.b. Chase .. $\quad .68 \quad 1.08$

Prices, PRINTED, One Line, One Side

REGULAR JUMBO $6 " \times 1 / 2 " 8 " \times 5 / 8 "$

Per 1,000 Per 1,000

2,000 to 4,000, f.o.b. Chase . . $\mathbf{1 . 5 9} \mathbf{2 . 1 4}$ 5,000 to 9,000 , f.o.b. Chase .. $1.34 \quad 1.84$ 10,000 and up, f.o.b. Chase .. $1.19 \quad 1.64$ Cannot print less than 2,000 total. ADD $10 \mathrm{c}$ per name when under 1,000; Add 10c per 1,000 for two lines. Cannot print less than 100 of a name. Ask for prices on large lots.

\section{LABELS-Indestructible Tree:}

An indestructible metal label to be used as a permanent marker. Available in COPPER and ZINC as listed below.

DIRECTIONS: Lay label on folded newspaper or other pad: write with hard pencil, nail or stylus (furnished in boxes of 100 labels), applying pressure to indent metal. Give wire one turn around branch, securing end in loop. Remove to smaller branch every few years to prevent girdling.

Single Eyelet-Tree, Bush, Bulb Label:

(Wire included)

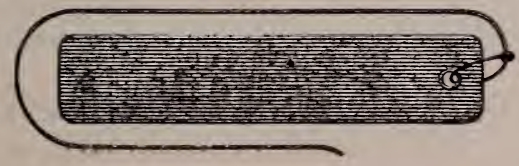

Style No. 2-Size $1 \frac{1}{8}$ x 5"

*Zinc Copper

Per 100, f.o.b. Chase ... $\mathbf{2 . 2 5} \quad \mathbf{3 . 5 0}$

Per 1000 , f.o.b. Chase ... $\mathbf{1 8 . 7 5} \quad \mathbf{3 0 . 0 0}$

* Reduced prices on ZINC due to a slight corrosion that has formed on some of the labels. They are still in a good usable condition. 
GRADING, PACKING AND SHIPPING SUPPLIES

(Continued):

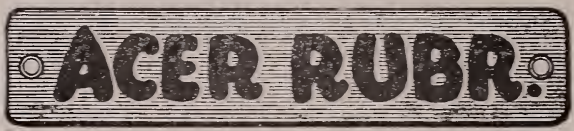

Item No.

Double Eyelet-Tree or Box Label:

(May be nailed or tacked on.)

Style No. 11 -Size $3 / 4 \times 3^{3 / 4}$ "-Copper:

$$
\begin{array}{r}
\text { Per } 100 \text {, f.o.b. Chase } \ldots \ldots \ldots \ldots . . \$ 2.50 \\
\text { Per } 1000 \text {, f.o.b. Chase } \ldots \ldots \ldots . . .20 .00 \\
\text { (500 Metal Labels at } 1,000 \text { rate) }
\end{array}
$$

\section{1-A. ALUMINUM WEATHERPROOF TAGS:}

Reinforced eyelet, copper wire, 31/2" long. Write on label with an orcinary lead pencil. Has a colored cardboard backing which can be used for additional temporary information. Will not rust or corrode, will last indefinitely. Double thickness of metal at each end of label for added strength. Packed 25 labels to a cellophane bag. Sample on request.

Per Package of 25 labels, postpaid $\quad .50$ Per 250 labels, f.o.b. Chase .... 4.50 Per 500 labels, f.o.b. Chase .... $\mathbf{7 . 5 0}$ Per 1000 labels, f.o.b. Chase .... 11.50

\section{MOSS, Sphagnum:}

Wisconsin's best grade of Sphagnum. This is known and used by florists and plant shippers from coast to coast. Packed in burlapped bales standard size. Sphagnum is scarce and high this year due to an unusually wet season which prevented harvesting. Most of our moss is having to be shipped lcl freight which doubles delivery costs. Will do our best for you. We have plenty of Peat Moss in stock, see Item No. 61.

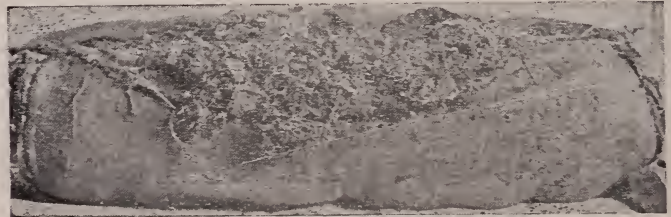

Per Bale, f.o.b. Chase ......... 2.65 (Regardiess of Quantity)

\section{Postage Extra--Guess Liberally}

WASHINGTON, April 25, 1950: "Our order No. 4385 arrived yesterday in perfect condition. We were very pleased with it and have planted it out in the nursery."

MISSOURI, April 25, 1950: "Thanks for the nice plants."

VIRGINIA, April 27, 1950: "Thanks folks for the courtesy. All items were in fine shape. Check to cover, \$120.15." 
GRADING, PACKING AND SHIPPING SUPPLIES

(Continued):

Item No.

Price

\section{GLOVES-Mule Skin:}

A high quality glove of good tough leather, soft and pliable permitting easy use of shears or knives when handling roses, etc. Three to four inch cuff protects the wrists. Large size only.

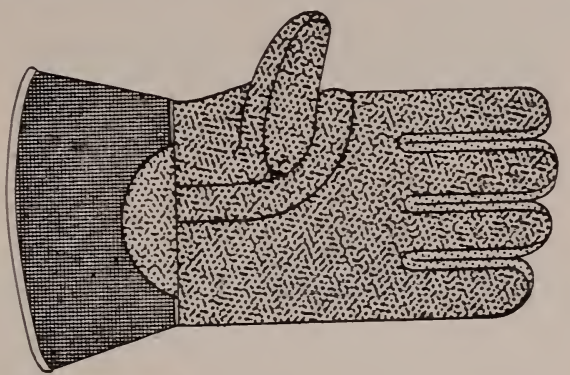

Per Pair, f.o.b. Chase ........\$2.15

Fer Dozen Pairs, f.o.b. Chase ..... 21.00

\section{NEEDLES:}

Best quality. Bagging or Sewing Needles. Large stiff shaft; wide, flat shank; sharp point and large eye.

Each Dozen

54-A-5-inch Needles, f.o.b. Chase .10

.95

54-B--6-inch Needles, f.o.b. Chase .13 1.35 54-C-7-inch Needles, f.o.b. Chase .16 1.75 (Half Dozen at Dozen Rate)

55. PAPER, Kraft (for Box Lining and Bales) Brown Kraft paper, 40 pound basis, good strength and resistant to moisture to a considerable degree. Best box-lining paper available. Widths 30 " and 40" weight about 47 pounds and 60 pounds respectively. State width wanted.

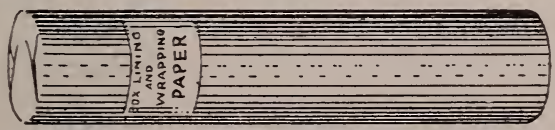

Per Pound, f.o.b. Chase ........ . 101/2 (Cannot break roll.)

55-A. PAPER, Waterproof Duplex-

\section{CRINKLED-}

Creped (or Crinkled) finish 25x25x25" waterproof paper. Width 36 " in rolls containing approximately 200 yards, with additional stretch of $331-3 \%$, weight approximately 75 pounds.

Per Pound, f.o.b. Chase ....... . .211/2

(Cannot break roll.) 
GRADING, PACKING AND SHIPPING SUPPLIES

(Continued):

Item. No.

\section{5=AX. PAPER, Waterproof:}

Price

Good quality waterproof paper, smooth (not crinkled) In rolls 36" wide containing approximately 200 yards.

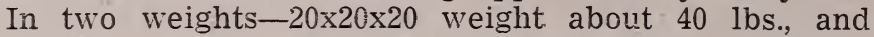
$25 \times 25 \times 25$ weight about 50 lbs. State which is wanted.

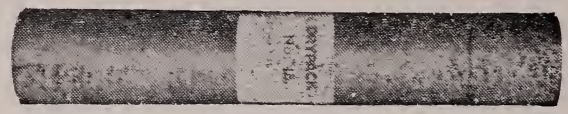

Per Pound, f.o.b. Chase .......\$ .18 (Cannot break roll.)

\section{AUTOMATIC ONE-HAND TACKER:}

We are delighted with this new Hansco Automatic. Merely grip the handle and "Zip, Zip" as fast as you

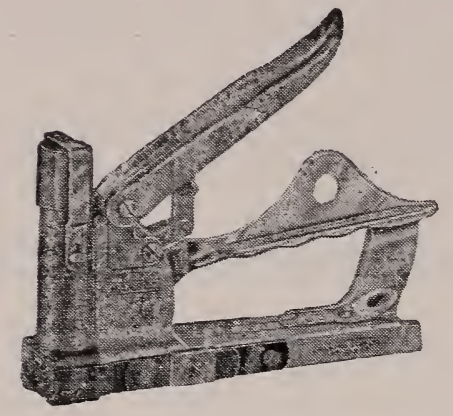
grip the Automatic Trip - Hammer drives the staple, leaving one hand free. For tacking shipping cards, paper lining boxes, or cars, etc., it's the latest word. Hansco "KlingTite" Staples No. 44 should always be used in these machines. We maintain factory repair service on these Hansco Tackers at a very reasonable charge.

56-A. Hansco Tacker, f.o.b. Chase, each 8.00 56-B. Hansco "K.T." Staples Per box of 5,000, f.o.b. Chase ... 2.00

\section{TREE COUNTER-Improved:}

In taking field inventory, as the operator passes down the nursery row he presses key indicating grade of tree or plant. When through with a variety the dial shows total number of each grade in the block. Absolutely accurate, simple and easy to use. Has large bold figures easily and quickly read. A good-looking, high class machine with many other uses wherever you need to "keep count." Complete with belt attached-just swing it around your waist, leaving both hands free. ONE REVOLUTION OF THE RE-SET KNOB RETURNS ALL UNITS TO ZERO.

(Continued on next Page)

NORTH CAROLINA, April 27, 1950: "The lining out stock was very nice and will like more. I am sending check for $\$ 200.00$ for the following."

ILLINOIS. April 28, 1950: "I received the order of Evergreens in fine condition."

KANSAS, April 28, 1950: “The Evergreens I received were very nice and I would like ycu to book me for 200 of the same for Spring delivery in 1951." 
GRADING, PACKING AND SHIPPING SUPPLIES

(Continued):

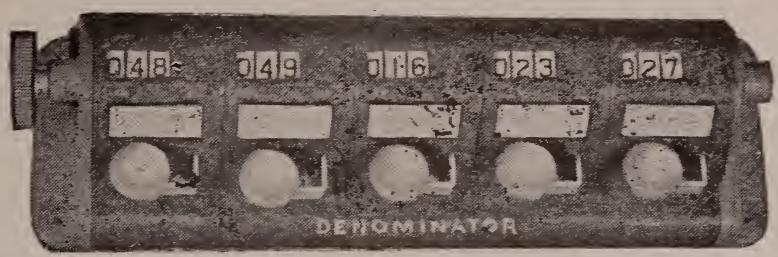

Item No.

Price

57-A. Four-dial Machine, f.o.b. Chase $\$ 32.50$ As shown, except has only four counting units. Counts to 999 .

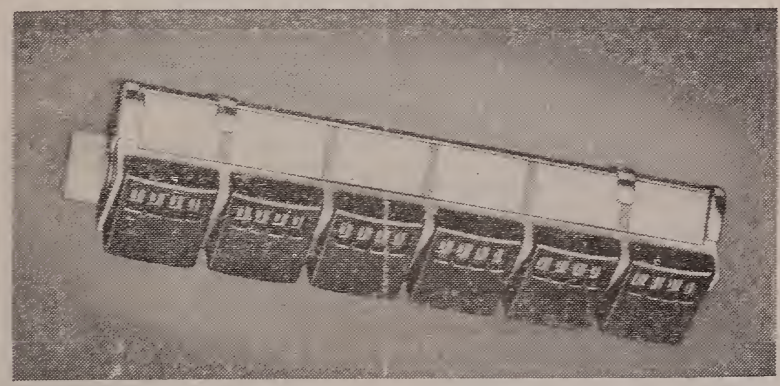

57-B. Five-dial Machine, f.o.b. Chase 39.95 As shown, except has only five counting units. Counts to 9,999 . New; Streamlined.

5\%.C. Extra Record Cards, For "old style" Tree Counters.

Per 500, f.o.b. Chase .......... 1.75

58. TREE GAUGE:

Designed by Herbert Chase. Both sides marked alike.

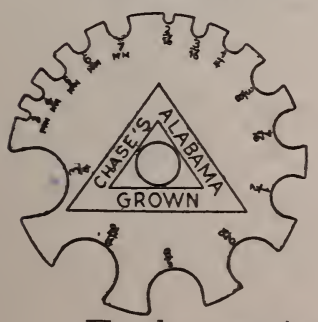
alvays right side up. Circular in shape, covering accurate caliper measurements 3 to 7 millimeters (for calipering seedlings) and $216 "$ to $3 / 4 "$. Rustproof; indestructible. Guaranteed accurate to within 1/1000 of an inch.

Each, postpaid

Dozen, f.o.b. Chase ......... 5.50

ILLINOIS, April 27, 1950: "Enclosed find check to cover invoice of April 21st. Stock was fine as always."

ILLINOIS, April 28, 1950: "The 500 Irish Juniper arrived in very good condition. Thanks for your prompt shipment."

PENNSYI,VANIA, April 28, 1950: "The stock was receivedvery nice service. You will find check enclosed."

OKLAHOMIA, Mäy 1, 1950: "I received the plants in good condition and they were very nice." 


\section{PROPAGATING SUPPLIES}

(Adhesive Tape, Grafting Thread, Grafting Wax, Peat Moss, Raffia, and Rubber Budding Strips.)

Item No.

Price

ADHESIVE TAPE-See Item No. 12.

\section{GRAFTING THREAD:}

Now available in tubes only. One tube will wrap on an average of 2,000 to 2,500 grafts, one box of 8 tubes will wrap about 16,000 to 20,000 grafts. We use this thread and can GUARAN'TEE it to be SATISFACTORY.

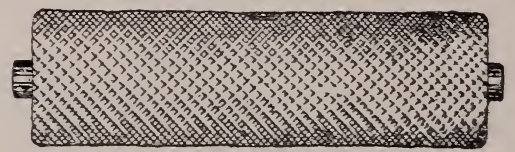

Unwaxed Waxed

Per Tube, f.o.b. Chase .....\$.35 \$.60 Per Box ( 8 tubes), f.o.b. Chase $\mathbf{1 . 9 5} \mathbf{3 . 6 5}$

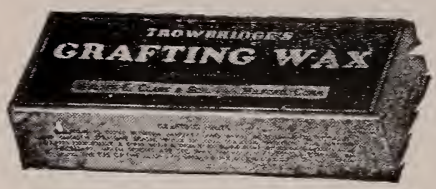

60. GRAFTING WAX

High grade grafting wax, put up in half pound packages. Complete directions a $\mathrm{n} d$ valuable grafting hints on wrapper.

Per 1/2-lb. Cake, f.o.b. Chase ...... .45

Per Pound, f.o.b. Chase ........ $\quad .80$

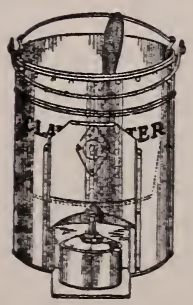

60-A. WAX MELTER

The Chase Melter. Burns alcohol or kerosene. Made of Galvanized Iron. For melting grafting wax, tar, paint, and glue. Adjustable wick for desired heat.

$1 / 2$-gallon size, f.o.b. Chase $\mathbf{6 . 5 0}$ 1-gallon size, f.o.b. Chase $\mathbf{7 . 5 0}$

\section{Postage Extra-Guess Liberally}

TEXAS, May 4, 1950: "Enclosed check is for box our plants were shipped in. The plants were very nice."

IMARYLAND, May 3, 1950: "We wish to state that the shipment of 2000 Biota aurea nana arrived in good condition, and we are well pleased with your stock."

PENNSYLVANIA, Miay 2, 1950: "The 200 Andorra liners I got from you were very nice, came good. Thanks. I hope we will do more business from year to year."

OHIO, May 6, 1950: "Thanks a lot for the liners boys, they are dandies! They are in the ground and making us money already. Thanks again for the good heavy grades and all other favors." 


\section{OFFICE AND MISCELLANEOUS SUPPLIES}

(Order Books, Bailey's Nursery Book, Tag Wire, Tree Paint.)

\section{BAILEY'S NURSERY BOOK:}

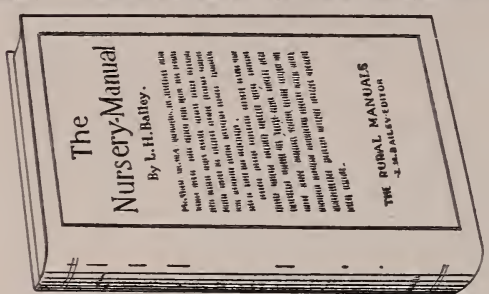

The best Nursery Manual. By Professor L. H. Bailey. One hundred illustrations. Written in simple, non - technical language, 456 pages.

Per Copy, f.o.b. Chase .......\$ $\mathbf{5 . 0 0}$

\section{2. "QUICKIE" WIRE TAG FASTENER:}

"Quickie" tag fasteners are 8" long, made of galvanized wire with a twisted loop on one end. A great time saver in attaching shipping tags-a simple twist and they are securely fastened. Packed 500 to package.

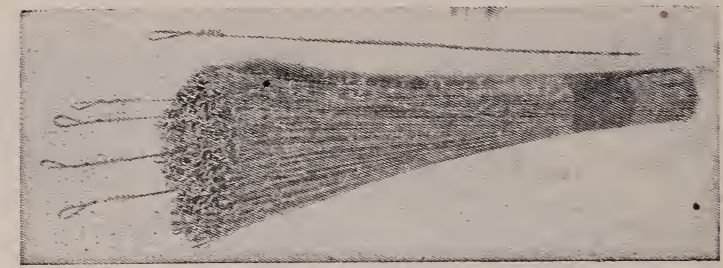

Per package (500), f.o.b. Chase ...

(Cannot break packages.)

\section{TREE PAINT_- "Treesaver":}

(Cut not available for this catalogue.)

We now carry two types of Tree Paint. This "Treesaver" is a thin liquid paint primarily for use in painting trees in the nursery row to prevent rabbit damage-apple trees, flowering crabs, etc. Discourages borers in dogwoods.

Per Gallon can, f.o.b. Chase ...... $\mathbf{2 . 5 0}$

Per Quart can, f.o.b. Chase ...... $\quad \mathbf{8 0}$

\section{Postage Extra--Guess Liberally}

MISSOURI, NIay 8, 1950: "We received another compliment of your Dogwood some of which we shipped to Springfield, Missouri. The report we got was the gardener that planted them said they were the finest in Springfield."

LOUISIANA, May 30, 1950: "Thanks for good service."

NEW JERSEY, June 5, 1950: "I want you to know I liked the stock you sent me and it arrived in excellent condition. This is more than I can say about a lot of other material I bought this year.",

NORTH CAROLINA, Sept. 12, 1950: "We are giving you this order, although we have better prices, because we feel that you will give us stock that will stand up before the inspector's eyes."

GEORGIA, Sept. 12, 1950: "This will acknowledge receipt of the labels today, and we wish to thank you for your prompt attention to our order and the good service we have received." 
MISCELLANEOUS SUPPLIES-(Continued):

Item No.

Price

76-A. TREE PAINT-"43 For the Tree":

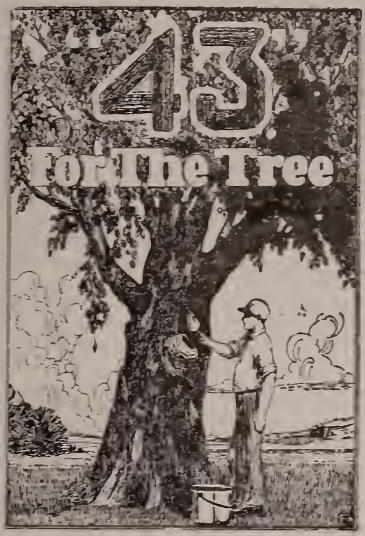

This is designed primarily for use in painting stubs and surfaces after pruning, or for painting cavities before filling. It is used very successfully by many tree surgeons and landscape gardeners. A can of it should be in the kit of every home owner who uses pruning saws and shears. It is most healing in its effect. Comes in either PLASTIC or LIQUID form.

LIQUID FORM is a heavy liquid that forms an air tight coating and should be applied on all pruned surfaces where the limb is $1 / 2$-inch in diameter or larger. The medicinal oils penetrate into all parts of the cut or wound. The acids and disinfectant odors will drive away worms.

PLASTIC FORM is used in filling small cavities, cracks, crotches, etc.

Prices are the same on both LIQUID and PLASTIC State which is wanted.

Per Gallon can, f.o.b. Chase .....\$2.50

Per Quart can, f.o.b. Chase ...... $\quad .80$

\section{TREE WRAP:}

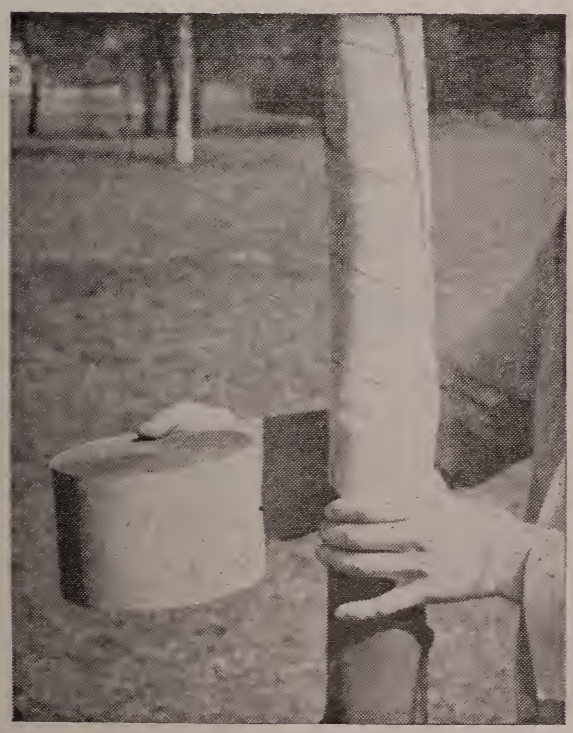

In rolls 4" wide, "8" in diameter, containing approximately 55 yards. Weight about $2 \frac{1}{2}$ pounds per roll.

Always start the wind at the top so that the lap will gather moisture.

Wrap to base of tree. Tie in place starting at base and spiraling in opposite direction of paper.

Per Roll, f.o.b. Chase ......... .70

Per Roll, 10 rolls and up, f.o.b. Chase $\quad .60$ 


\section{SALES AIDS}

Item No.

Price

\section{FLATE BOOK:}

Complete assortment of Coniferous Evergreens, Broadleaved Evergreens, Shrubs, Roses, Vines, Hedge, Trees, Bulbs, Hardy Perennials and Fruits. Size $81 / 2 \mathrm{X}$ 11", 64 pages containing 276 beautiful full color plates. Ideal for your office, sales yard, or salesman on the road. Each item described fully and shown in color.

Each, f.o.b. Chase ........\$ 2.50

\section{CHASE'S SHRUB CHART:}

A choice selection of 30 flowering shrubs in full natural color, 381/2" long by 25" wide. Truly a work of art, and an excellent sales help.

Each, postpaid ........... 2.50

\section{Postage Extra-Guess Liberally}

TEXAS, November 8, 1949: "We wish to thank you for the prompt shipment of the pruners received a few days ago. We are enclosing stamps to cover postage of $73 \mathrm{c}$ which was not included in our check."

ALABAIMA, Dec. 13, 1950: "Enclosed find my check for $\$ 2.15$ for which please send me No. 3 Budding and Grafting Knife. Several years ago I purchased from yout a similar knife "Say it with Flowers" which was one of the best knives I ever had."

ALABAMA, Jan. 23, 1950: "Enclosed is 12c in stamps for postage on pocket knives. Thanks very much for your promptness in sending them."

ILLINOIS, Jan. 28, 1950: "We wish to thank you for your prompt attention to our order for copper wire which was received today."

FLORIDA, March 28, 1950: "We are weil pleased with the Leonard Spade."

TEXAS-"You shipped those bud bands that I ordered at once which I appreciated very much."

ILLINOIS, Sept. 15, 1950: "Somebody stole our colored shrub chart and we will be forced to go out of business unless we have another immediately."

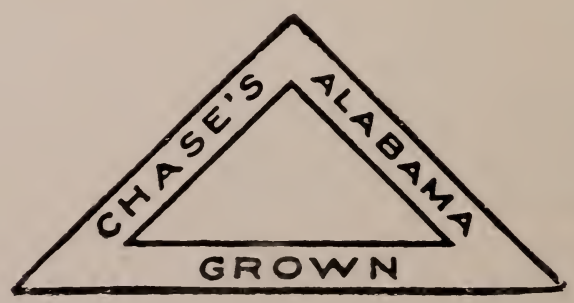




\section{W E I G H T S}

To help you determine delivered cost of Nursery Stock, we have compiled the following table, which shows APPROXIMATE AVERAGE SHIPPING WEIGHTS:

\section{Shrubs}

4- $5, \ldots \ldots \ldots \ldots, 350$ pounds per 100

3. 4, ...........250 pounds per 100

$2.3, \ldots \ldots \ldots \ldots \ldots 175$ pounds per 100

$18-24 " \ldots \ldots \ldots \ldots \ldots 100$ pounds per 100

$12-18 " \ldots \ldots \ldots \ldots \ldots \ldots .75$ pounds per 100

\section{$B \& B$ Conifers and}

Broadleaved Evergreens

6- 8, $\ldots \ldots \ldots \ldots \ldots \ldots 120$ pounds Each

5. 6 , $\ldots \ldots \ldots \ldots \ldots \ldots \ldots, 90$ pounds Each

4- 5, $\ldots \ldots \ldots \ldots \ldots \ldots, 80$ pounds Each

3. 4, $\ldots \ldots \ldots \ldots \ldots \ldots, 50$ pounds Each

2. 3, ............ 40 pounds Each

$18-24 " \ldots \ldots \ldots \ldots \ldots \ldots .35$ pounds Each

$15-18 " \ldots \ldots \ldots \ldots \ldots \ldots, 30$ pounds Each

\section{Vines}

2-Year No. $1 \ldots \ldots \ldots 120$ pounds per 100 2-Year Medium ...... 85 pounds per 100

\section{Hedge Plants (Privet)}

2. 3, $\ldots \ldots \ldots \ldots \ldots, 120$ pounds per 100 $18-24 " \ldots \ldots \ldots \ldots \ldots \ldots .85$ pounds per 100 $12-18 ” \ldots \ldots \ldots \ldots \ldots .45$ pounds per 100

Roses

2-Year No. $1 \ldots \ldots \ldots 100$ pounds per 100 2-Year Medium ....... 65 pounds per 100 2-Year No. $2 \ldots \ldots \ldots, 30$ pounds per 100 


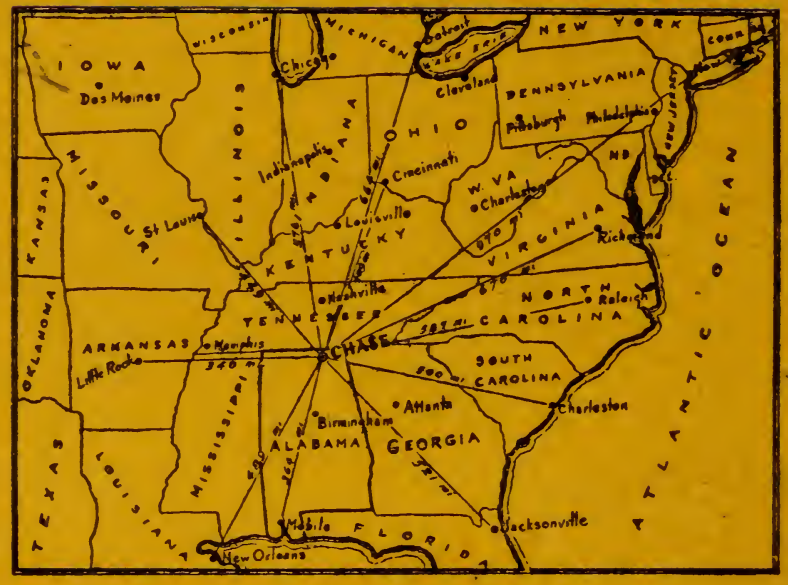

IT'S NOT FAR TO CHASE-FLORIDA BOUND TRAVELERS TAKE NOTE 